$n$ these hectic times, it seems many have forgotten about one of life's simplest and yet most enjoyable pleasures - reading a book. Through its Readings section the Bulletin strives to remind its readers about all the worthwhile (and occasionally not-soworthwhile) reading that is available. In our annual book issue this month, we expand on this goal by spotlighting some of the past year's most distinguished books in the field - Hurricane Watch, by Bob Sheets and Jack Williams; The Rainbow Bridge, by Raymond L. Lee Jr. and Alistair B. Fraser; and The Coldest March, by Susan Solomon. We also provide a categorized list of all the books that were announced and reviewed in the Bulletin in the past year, and we catalogue all of the available AMS publications. After all that, if you are still having trouble finding something to read, below we give you "Editors' Picks" — some recommended reading from the Bulletin's editorial board. We hope these suggestions might inspire you to ask your own colleagues about what they're reading. After all, as Ralph Waldo Emerson said, "If we encounter a man of rare intellect, we should ask him what books he reads."Matthew Gillespie, Book ReVIew Editor

\title{
EDITORS' PICKS
}

\section{ED ZIPSER}

THE PERFECT STORM: A TRUE STORY OF MEN AGAINST THE SEA-Sebastian Junger

Other than gaining an appreciation of the everyday life and hazards (economic more than meteorological) faced by the fishing industry, this was more like reading a novel. I didn't learn anything about the storm that I didn't already know.

\section{ISAAC'S STORM-ERIK LARSON}

As a tropical meteorologist since my grad school days in Tallahassee, hurricanes and their impacts have been high on my list of concerns and interests. This book was interesting in bringing to light some of the lesser-known details of the ominous warning signs in Galveston before disaster struck, how denial of the (now) obvious contributed to the disaster, and how little could really have been done to save the victims once the storm got close. The alternative viewpoints of the actions of Isaac Cline added an interesting new dimension to the story as well.

\section{RISING TIDE: THE GREAT} MISSISSIPPI FLOOD OF 1927 AND HOW IT CHANGED AMERICA

\section{-JOHN M. BARRY}

I have to admit that I picked up this book because of its meteorological context. Very quickly, however, I became drawn into it for its wonderful illumination of the history of the wrong-headed attempt of man to control nature, the hubris of engineers, the greed that dominated so many of the decisions that preceded and accompanied the tragedy of the flood itself. I was especially interested in the history of race relations and other social interactions in the Mississippi Delta and New Orleans, and how they were influenced by the levee development and overall management decisions by federal, state, and local officals.

\section{PETER BLANKEN} IN THE HEART OF THE SEA: THE TRAGEDY OF THE WHALESHIP ESSEX-Nathaniel Philbrick The tragic true account of the sinking of the whaleship Essex in 1820 that served as inspiration for Herman Melville's Moby Dick. Well written and thoroughly researched.

ANGELA'S ASHES-FRANK MCCOURT The poignant autobiographical account of a young Irish boy growing up in poverty in the 1930's. An exceptional book written with an ironic balance between desperation and humor.

\section{WALT DABBERDT} BRUNELLESCHI'S DOME: HOW A GENIUS REINVENTED ARCHITECTURE-Ross KING The story of watchmaker Filippo Brunelleschi, who implemented the 14th century design for the dome of Santa Maria del Fiore in Florence. 
WAR IN A TIME OF PEACE: BUSH, CLINTON AND THE GENERALSDavid Halberstam

A very insightful account of $1990 \mathrm{~s}$ politics, politicians, the military, and the war in Bosnia. A great prelude to our current administration and the war in Afghanistan.

\section{JENNI EVANS}

GENOME-MATT RidLEY

Although its only link to weather is an unfortunate swipe at climatechange research, it's a fascinating exploration of recent results of genetics research at a non-specialist level. It includes commentary on the human genome project goals and findings, as well as brief discussion on stem cell research and other quite topical matters.

\section{TOM FAHEY}

\section{THE SPIRIT OF LEADERSHIP}

\section{-Robert J. Spitzer}

I bought this book a year ago when my daughter, then a senior in high school, and I visited Gonzaga University. Rev. Spitzer, president of Gonzaga, delves deeply into the intangibles of leadership-spirit, trust, and vision-and its impact within an organization. The book provides a balanced look at business as well the true essence of the human spirit. I have gone back to the book a number of times over the last year and used it as both a business and personal reference. It has provided a solid foundation to at times regain my grounding as I deal professionally in the business world and at others to climb a little further toward a life lived well.

\section{DESCARTES' ERROR: EMOTION,} REASON AND THE HUMAN

BRAIN-ANTONIO R. DAMASIO

Since my son was born with a brain injury, reading this book was both scientifically intriguing as well as personally and emotionally charged. The hypothesis of the links between human emotions/ feelings and human reason/social behavior are explored. It describes the day-to-day lives of patients with specific brain injuries, the loss of emotions, and the loss of an ability to choose the most advantageous course of action while having no measurable loss of intelligence. It goes on to describe the current scientific knowledge of the function of the brain and proposes that emotions are a key to wise decisions, rather than an obstacle.

\section{BILL HOOKE} HISTORICAL PERSPECTIVES ON CLIMATE CHANGE-James Rodger FLEMING

This book has been on my shelf for awhile, and I confess to having got round to reading it only recently. Even though it was published four years ago, my guess is very few from our community have read it and more ought to. It's a crisp, quick read (only 194 pages), but provides a wonderful look at the evolution of thinking about climate change, and really puts today's work in a much richer context.

\section{DISASTER! THE GREAT SAN} FRANCISCO EARTHQUAKE AND FIRE OF 1906-DAN KURZMAN Kurzman's writing style is not the best, but his sense of story and the dramatic is top notch. This is a spellbinding story, and it highlights the conjunction of natural extremes and social brittleness that characterizes every major disaster.

\section{WALT LYONS}

THE INVENTION OF CLOUDS

-Richard Hamblyn

December 2002 will mark the 200th anniversary of Luke Howard's famous address to a London scientific society in which he proposed the nomenclature system for clouds that is still essentially in use today. This book brings many lessons. The need for proper terminology is a bedrock for scientific investigation. It also highlights how a dedicated individual practicing "small science" can have a profound influence on the development of a discipline. Even today, not all scientific advances are the result of mega-programs and their huge budgets.

GERMS-Judith Miller, Stephen

Engelberg, and Willam Broad

Though written before September 11 , this book outlines the shadowy world of biological warfare both in the United States and worldwide. As meteorologists, we may become more involved in homeland defense than we might ever have imagined possible when one considers the atmospheric component of the deployment of weapons of mass destruction.

\section{JEFF ROSENFELD}

THE ARTS OF DECEPTION: PLAYING WITH FRAUD IN THE AGE OF BARNUM

-JAMES W. COOK

This glimpse into American tastes of yore has plenty of surprising insights into popular amusements from magic tricks to trompe l'oeil. Best of all, though, Cook's thoroughly researched, entertaining stories help us probe our own propensity for mental puzzles and visual thinking and show how the public absorbs technical accomplishment. This history is a fresh approach to the era in which meteorology took root and suggests reasons for why the road to popular respectability can be so bumpy. 


\title{
WRITING THE COLDEST MARCH
}

\author{
BY SUSAN SOLOMON
}

\begin{abstract}
"No one in the world would have expected the temperatures and surfaces which we have encountered at this time of the year.... It is clear that these circumstances come on very suddenly, and our wreck is certainly due to this sudden advent of severe weather, which does not seem to have any satisfactory cause."-ROBert Falcon SCOTT, message to the public, March 1912
\end{abstract}

n November of 1911, Captain Robert Falcon Scott led a British team across the snows of Antarctica, striving to be the first to attain the South Pole. After marching and skiing over 900 miles, Scott and four companions reached their goal in January of 1912, only to find that a group of five Norwegians headed by Roald Amundsen had been there about a month earlier. Antarctica's most tragic legend was born as Scott and his polar party all perished on their return journey over the Ross Ice Shelf.

I first visited Antarctica more than seventy years after Scott's death. I went there to do research on the ozone hole that has made the most remote place on this planet the site of one its most spectacular examples of environmental change.

In spite of its small and transient population, Antarctica has a form of culture, and it certainly has a history-especially its history of exploration. Today's Antarctica has stories, legends, heroes, ghosts, and villains. For many visitors to this unusual place, particularly visitors in the American science program, Scott and his men's places in that culture are as the clowns, as caricatures who committed mistakes of inane proportions.

I confess that I signed on to that one-dimensional view of Scott's expedition when I first learned about it. But over a period of 14 years during which I made four visits to the Antarctic, I slowly went back to the original sources to learn more. It was an entertaining hobby, one that I never imagined would become much more than an enjoyable gamut of bedtime reading. But as I studied the men's own books and diaries, I found pieces to the complex puzzle of what happened to them not just in one but in the combi- nation of all of their personal accounts. I also began thinking more deeply about what we know now, as a result of decades of Antarctic science, that Scott and his men couldn't have known in 1912. As I read the words of dying men who wrote that "the weather conditions are awful," and lamented the "impossible friction (of the cold snow)" which made "the sledge ... heavy as lead," I wondered in particular about the role of the weather.

Even when one lives the life of easy comfort of a contemporary scientist in Antarctica, there are glimpses of what Scott and his men experienced: one learns that a person acclimatizes, even feels quite warm at $-20^{\circ} \mathrm{F}$ ("an improvement which makes us much more comfortable") but that at $-40^{\circ} \mathrm{F}$ Antarctica becomes a far more hostile place, a world "desperately cold." I thought someone should have a closer look at what sort of weather Scott and his men expected and what they actually encountered on their tragic journey to and from the Pole. I compared the measurements that Scott and his men meticulously recorded during day after day of grueling marches to the modern record made possible by the invention of the automated weather station and the dedication of the team at the University of Wisconsin who deploy them around Antarctica. Putting that information together with the records left by Scott's meteorologist, George C. Simpson, revealed that these unlucky explorers had carefully considered the weather and had forecast with stunning accuracy what it should have been like. But they were caught in a very unusual and prolonged cold event on their return journey from the Pole, a devastating weather event that probably occurs roughly only once in 15 years on the Ross Ice Shelf. It was at this point that I knew I had to write The Coldest March, to show how a group of scientific men studied carefully, planned well, and yet met their end through sheer bad luck. The book focuses on the weather, but it also describes other aspects of science, such as nutrition, materials science, and snow physics that bear upon the plight of these early explorers. It also focuses on the men themselves: their characters, their struggle, their friendships, and their humanity. 
One surprise to me has been the difficulty some nonscientific readers have had in understanding that my goal in writing this book was to tell a balanced story in all its facets, to describe what Scott and his companions did right as well as what they did wrong. This has confused some readers, who expect all such books to present a one-sided picture: either a case for the prosecution or a case for the defense. I should perhaps have expected this after 20 years of doing research on ozone, in which I certainly learned that the public sometimes yearns for simple answers. But The Coldest March has sharpened my own understanding of the problem of describing how science works, and has brought into focus the reason why our challenge is so great in communicating scientific information to the public. Good science is brutally honest, and honesty sometimes doesn't allow for a one-sided story, especially where human beings are concerned. The Coldest March is a story of science, of difficult choices, and of tragic mistakes; it is also a story of the awesome power of weather and the even greater power of human courage and loyalty. It tells the story not just of what Scott and his men did and how they died, but also why, and I hope that it will leave all its readers with a less one-dimensional picture of a remarkable team of heroic explorers.

Susan Solomon is widely recognized as one of the leaders in the field of atmospheric chemistry. Since receiving her Ph.D. degree in chemistry from the University of California at Berkeley in 1981, she has been employed by the National Oceanic and Atmospheric Administration as a research scientist. In 1986-87, she served as the head project scientist of the National Ozone Expedition at McMurdo Station, Antarctica, and made some of the first measurements there that pointed toward chlorofluorocarbons as the cause of the ozone hole. In 1994, an Antarctic glacier was named in her honor in recognition of that work. For her pioneering work on measurements and interpretation of the ozone hole, she was honored with the American Meteorological Society's Rossby Medal in 2000. In March of 2000, she received the National Medal of Science, the United States' highest scientific honor, for "key insights in explaining the cause of the Antarctic ozone hole."

The following passage is excerpted from The Coldest March: Scott's Fatal Antarctic Expedition, pages 136-14I, by Susan Solomon (200I, Yale University Press, 383 pp., hardbound, \$29.95, ISBN 0-300-08967-8). Copyright (C) 2001 by Susan Solomon. Reproduced by permission of Yale University Press (P.0. Box 209040, New Haven, CT 09620-9040; I-800-YUP-READ; www.yale.edu/yup/). All rights reserved.

1

n spite of heavy loads, the going was relatively easy when the three men set off over the smooth sea ice on June 27, 1911. The next day they marched past Hut Point and soon reached the edge of the Barrier. As they stood at the base of the snow-covered uphill slope to the Barrier, down came "a steady stream of very cold air which we noticed only a few yards from the bottom." Wilson documented the remarkable transition in temperature as they marched from Hut Point up the slope to the tip of the Barrier-from $-26.5^{\circ} \mathrm{F}$ to $-47^{\circ} \mathrm{F}$ in just a few miles. Cherry-Garrard noticed the plunge into deep freeze in a more personal fashion. In an instant of poor judgment, he took off his fur mitts so that he could better pull the sledges up the hilly grade onto the Barrier. Although he had thin inner gloves on under the mitts, all ten of his fingers were quickly frostbitten. They were covered in inch-long blisters within a few hours. The pus inside the blisters subsequently froze, and his damaged fingers gave Cherry-Garrard a great deal of pain in coming days.

As on earlier sledging trips, the critical reserves of oil were not meant to be used for anything other than cooking. But as conditions grew desperately cold, the men burned more in order to warm the air inside the frigid canvas tent. Eventually Cherry-Garrard managed to defrost his solidly frozen blisters over the cooking stove during supper one night. He pricked them and felt great relief when the liquid ran out.

The three men struggled on in temperatures of $50^{\circ} \mathrm{F}$. Wilson developed a frostbitten heel and sole on one foot, and Cherry-Garrard's big toes were bitten as well. Only the resistant Bowers was "never worried by frostbitten feet." They were beginning to enter the region between Hut Point Peninsula and Mount Terror ... which was known to be a place of little wind. 
Though sheltered from the flow of air off the Barrier, this bowl-like bight with its sandy snow was a place of torture for the trio. The very cold surface gave the sledges no glide, and the men were forced to begin the dreaded process of relaying their loads. The already difficult plod now became a misery of marching forward with half of their supplies, then going back to retrieve the rest. They steered their course by the light of Jupiter when the planet could be seen through the clouds. They spoke little, but one matter they did discuss was whether the conditions they were encountering were normal, or whether it was a particularly cold snap. They also discussed turning back, but each time the subject arose, they resolved to continue. Sweat and breath accumulated in their frigid sleeping bags each night as they tried to rest. CherryGarrard spent the last night of June in a dreadfully cold and damp reindeer bag, suffering a series of shivering fits and listening to Bowers snore.

The evening of July 3 brought temperatures near $-60^{\circ} \mathrm{F}$ and a magnificent aurora. The three men lay on their backs with their faces to the wonderful light show in the sky, but only two of them could see the celestial display. The doctors had nearly refused to let Cherry-Garrard join the expedition because of his severe nearsightedness. In the extreme cold of the winter journey, the glasses on which he depended became useless, constantly fogged by moisture from his skin and breath. He was forced to give up wearing his lenses on most of the winter journey and was essentially blind except for close work.

The men's sleeping bags were becoming heavier with the ice of each passing day's perspiration and each night's fitful rest. Getting into the increasingly icy bags became a torturous process of slowly worming their bodies into the fur, gradually melting the ice with their own bodily warmth. This ritual of pain could take as much as an hour. In spite of an eiderdown liner, Cherry-Garrard's sleeping bag was too big for him and hence even more uncomfortable than it would otherwise have been.

The minimum temperature on the night of July 3 was $-65^{\circ} \mathrm{F}$, but a gusty wind began on the morning of July 4 , and by 9:30 the temperature had risen to a

\section{IAHS Soil-Vegetation- Atmosphere Transfer Schemes and Large-Scale Hydrological Models}

\section{Edited by A. J. Dolman, A. J. Hall, M. L. Kavvas, T. Oki \& J. W. Pomeroy}

Soil-vegetation-atmosphere transfers (SVATs) determine, to a large extent, the global climate and the behaviour of the hydrological cycle. Model predictions depend critically on adequate parameterization of these interactions but this has yet to be achieved in several key areas. Current SVAT schemes include complex descriptions of the mechanisms governing land surface processes requiring large numbers of parameters controlling the vertical fluxes. The underlying rationale is that improved process representation will result in parameters that are easier to measure or estimate, and in better model performance and robustness, but this is not necessarily so. The papers in this volume address these issues.

IAHS Publ. no. 270 (July 2001) ISBN 1-901502-61-9 (372+x pp.) Price $£ 59.50$ including surface mail postage, discounts for IAHS members. Payment maybe by VISA, MasterCard, EUROCARD Please send orders and enquiries to:

Jilly Gash, IAHS Press, Centre for Ecology and Hydrology, Wallingford, OX10 8BB, UK; e-mail: jilly@iahs.demon.co.uk

For information on other IAHS publications, meetings, activities and membership, see: www.cig.ensmp.fr/ iahs

\section{Your Equipment to Measure}

\section{Rain Drop Size Distributions...}

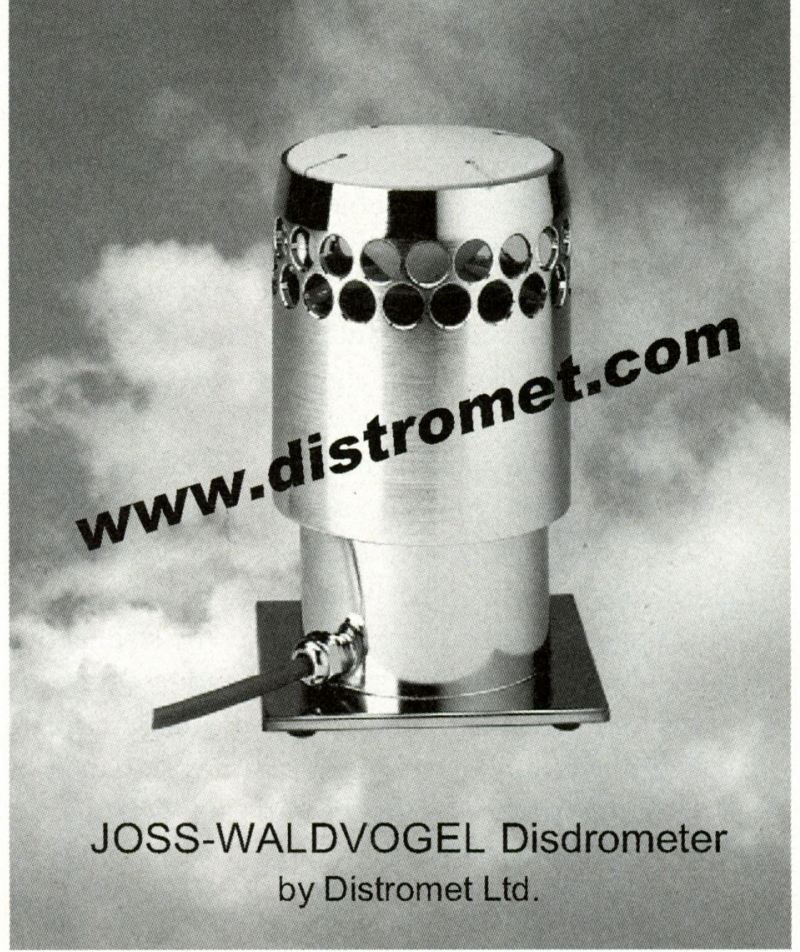


relatively balmy $-27.5^{\circ} \mathrm{F}$. The trio stayed in their bags and waited for the wind to die down....

At about 4:30 in the afternoon that day, Dr. Atkinson took it upon himself to walk out to read the meteorology screens; because Bowers and Wilson were away, this duty required a new volunteer. With winds in excess of thirty miles per hour, the doctor decided to take readings not only from the screen nearest the hut but also from the one on the sea ice, about a mile to the northeast. When he had not returned by 6 P.M., a search began. As the hours passed the men grew more desperate. After first mistaking a dead seal for the body of the missing doctor, one searcher finally heard footsteps on the ice nearby, and the doctor was found at about midnight. Doctor Atkinson had suffered serious frostbite on three fingers of his right hand as a result of his harrowing experience, and seaman Evans bandaged and cared for the wounds. Twenty-four hours passed before sensation finally returned to all of the doctor's afflicted fingers.

The air was calm again on the Barrier the next day, and Wilson, Cherry-Garrard, and Bowers pushed on. But the storm had left a fresh layer of cold and even less tractable snow on the surface. Although the Cape Crozier trio did not use skis themselves (mainly to avoid breakage in the darkness), the runners of their sledges acted as skis carrying their provisions. The much greater friction of new snow compared with aged surfaces, a well-known characteristic to any skier, results from the sharp edges of new crystals. As temperatures fall below about $-20^{\circ} \mathrm{F}$, friction further increases because lubrication is impeded at cold temperatures. These were problems that Scott's expedition was to encounter with debilitating intensity in coming months. The Cape Crozier trio experienced them in vivid fashion on July 5 , for they advanced a total of only 1.5 miles in eight exhausting hours of heavy pulling.

On July 6, the air remained still and the noon temperature sank to an astonishing value of $-77^{\circ} \mathrm{F}$. To be sure of this remarkable figure, the men checked it with two thermometers. The intense cold now made every task a slow agony. The strings that tied their bags of pemmican, butter, and biscuits were like wire. It was impossible to handle any item with naked fingers, and every bit of camp work had to be done slowly while wearing fur mitts. By this time, the men's sweat and breath had begun to turn their clothing into armor plate. Cherry-Garrard made the mistake one morning of raising "my head to look round and found I could not move it back. My clothing had frozen hard as I stood-perhaps fifteen seconds. For four hours I had to pull with my head stuck up and from that time we all took care to bend down into a pulling position before being frozen in."

Moisture also posed a threat to the all-important matches that were needed to light the cooking stove. The matches quickly collected condensation when taken from the dry cold outside into the wetter air of the tent. Sometimes four or five boxes were tried before one match successfully burst into precious flame.

The Cape Crozier party's tent was double-lined, with an outer layer of windproof canvas and an inner light lining. Although the layer of air helped to insulate their shelter, the lining also collected rime from their breath, sweat, and cooking, becoming heavier with each passing day. They young Australian Debenham thought about the lonesome trio absent on the Barrier, writing, "I should think that never before has such a tremendous discomfort been undergone for scientific research and the emperors should be highly honored."

As the three men struggled along, the snow gradually became firmer and easier to negotiate, signaling that they were moving past the worst part of the windless area. Wind is another key factor that influences the character of a skiing surface. Strong wind stiffens the surface of Antarctic snow, changing its dry character from soft and powdery to a porous but hardened texture that greatly eases ski or sledge travel.

July 9,1911 , was a relatively warm day at $-36^{\circ} \mathrm{F}$, but fog made the going difficult, and by afternoon the trio was surrounded by the crevasses that are spawned by the slow flow of the Barrier past the land near Cape Crozier. They "stood still and heard the ice creaking and groaning ever so deep down under us and all around." They camped in a hollow that appeared to be more stable, although noises like "some giant ... banging a big empty tank" came from under the tent. After supper a strong wind began to blow. It was to last three days and drive the temperatures up to a remarkable $+9^{\circ} \mathrm{F}$. For the first night in many, they all slept in welcome warmth. 


\section{Atmospheric Sciences Knowledge in One Comprehensive Resource}

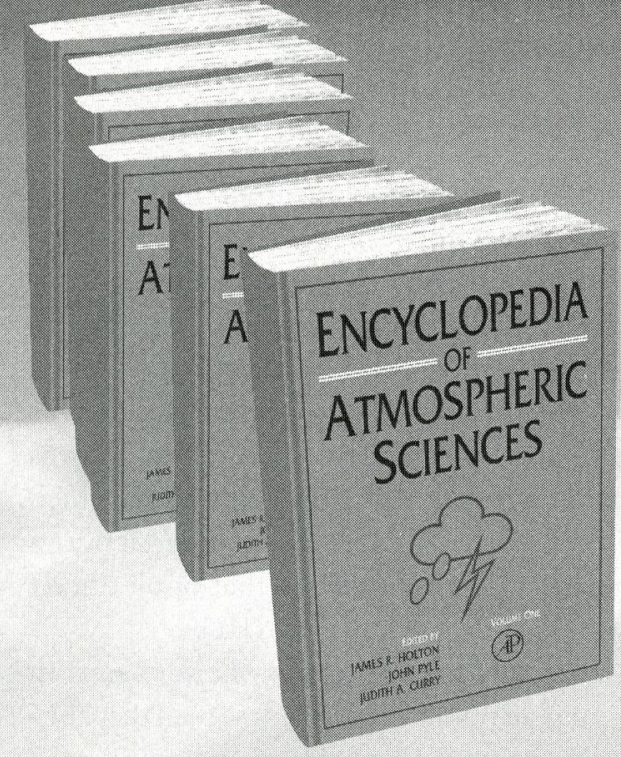

Editor-in-Chief

\section{James R. Holton}

University of Washington, Seattle, U.S.A

\section{Editors}

\section{John Pyle}

University of Cambridge. U.K.

\section{Judith A. Curry}

University of Colorado, Boulder, U.S.A.

\section{October 2002}

Six-Volume Set, c. 3000 pp.

Introductory Price: \$1,199.00 / £799.00*

List Price: $\$ 1,400.00 / £ 935.00$

ISBN: 0-12-227090-8

*Introductory price valid through end of third month following publication

\section{ORDER from your favorite bookseller or directly from:}

In the U.S. and Canada:

ACADEMIC PRESS

Order Fulfillment Dept. DM27098

6277 Sea Harbor Drive

Orlando, FL 32887

Call Toll Free: 1-800-321-5068

Fax: 1-800-874-6418

E-mail: ap@acad.com

All other countries:

ACADEMIC PRESS

Customer Service Dept.

Foots Cray High Street

Sidcup, Kent DA14 5HP, UK

Tel: +44 (0) 2083085700

Fax: $+44(0) 2083085702$

cservice@harcourt.com

All prices and publication dates subject to change without notice.

Q 2002 by Academic Press. All Rights Reserved. KS/VA/EES-17052 $3 / 02$
E N C Y C L O P E D I A O F

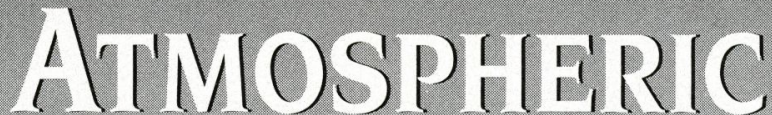

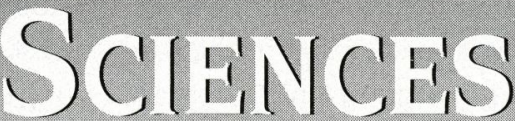

\section{Six-Volume Set}

- Covers all aspects of atmospheric sciences, including both theory and applications

+ Presents more than 350 articles and over 1,900 figures and photographs

- Broad ranging articles include topics such as biogeochemical cycles, boundary layers, clouds, general circulation, global change, mesoscale meteorology, ozone, radar, satellite remote sensing, and weather prediction

- An ideal resource for academia, research, government, and industry in the fields of atmospheric sciences, ocean sciences, and environmental sciences
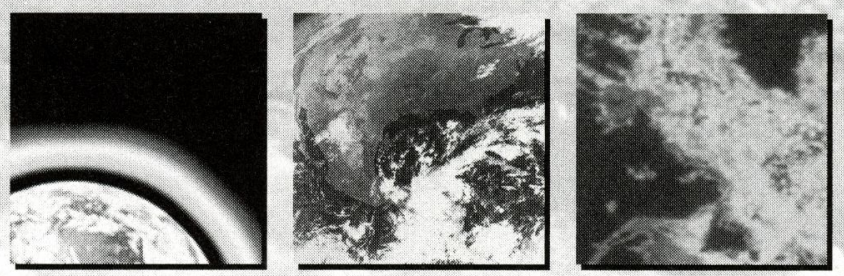

Tell Me More! Register for free progress alerts at www.academicpress.com/atmospheric. We'll also keep you up-to-date on the electronic version currently in development and let you know when we've posted sample pages and the list of articles, authors, and affiliations on the site.

\section{Related New Books}

An Introduction to Atmospheric Gravity Waves

An Introduction to Atmospheric Radiation, 2e

Dynamical Paleoclimatology

Introduction to Micrometeorology, 2e

Mesoscale Meteorological Modeling, 2e

Meteorology at the Millennium

Spectral Imaging of the Atmosphere

Complete details at:

www.academicpress.com/geoscience 


\title{
WRITING HURRICANE WATCH
}

\author{
By BOB Sheets
}

0 ver a 40-year career in the field of meteorology, with 35 of those years specializing in the study and forecasting of hurricanes, I have observed and participated in many changes in my chosen field. This period spans the era of almost total reliance upon analytical studies and detailed analyses of any scrap of available observations from ships, island stations, and aircraft for use in providing hurricane forecasts and resultant warnings, to one of heavy reliance upon time-lapse satellite imagery, modern-day aircraft observations, and numerical guidance for making such forecasts. During this period, I had the great privilege of knowing, observing, and sometimes working directly with-and always learning from-some of the post-World War II pioneers in our field-some well known, others not so well known-such as Herbert Rheil, Bob and Joanne Simpson, Gordon Dunn, Noel LaSeur, Cecil Gentry, Banner Miller, Charles Jordan, Harry Hawkins, Ted Fujita, Ray Kraft, Arnold Sugg, and more contemporaries such as Neil Frank, Gilbert Clark, and Bill Gray. Very few meteorologists working in the field today are fully aware of the accomplishments and importance of those who came before them.

Sixteen of the 33 years I spent in government service were at the $\mathrm{Na}$ tional Hurricane Research Laboratory and its successors, all located within the National Hurricane Center (NHC), with 15 years in the latter organization (the last seven as its director). This time included the period when Hurricane Andrew - the greatest natural disaster in the history of the United States to date, in terms of economic loss-occurred.

During that period, I authored many papers published in scientific journals as well as in more popular media. I also made numerous presentations at scientific meetings, to Emergency Management and other governmental and industrial decision-making officials, and to the general public, literally speaking before tens of thousands of people. Based upon comments and interactions at those presentations, it was clear that there was a need for a popular book on hurricanes that told what we know and do not know about hurricanes today, including limitations on forecast skills, the impact hurricanes can have when striking selected coastal areas, and how we can realistically reduce losses of life and property from hurricanes. In most of my presentations, I relied heavily upon visual aids, such as photographs illustrating the structure as well as the impacts of hurricanes. Frequently, I was asked if I had this material available in a book, which I did not. I then started accumulating material over a period of years, planning to write that book once I retired from full-time work at the NHC.

However, I really did not know where to start in getting a reputable publisher for widespread distribution of the finished product, or how to organize the book in a form that would appeal to such a publisher. Fortuitously, shortly after I retired from NHC I received a call from Jack Williams, with whom I had interacted for several years and knew as an excellent science writer, asking if I would like to collaborate on a book on hurricanes! I thought that we would make an ideal team, and Jack already had the experience of putting together The Weather Book. We then put together a detailed proposal of 16 pages with the idea that the style of the book would be a cross between National Geographic and The Weather Book, utilizing numerous illustrative drawings and photographs. We would start with a brief history of early encounters with hurricanes and efforts to learn about them. We would then work our way forward in time to talk about research and forecasting advancements after World War II, including hurricane reconnaissance and the development of other observational tools, such as weather satellites. We would include a brief section on hurricane modification research; then the latest scientific understanding of hurricanes, as well as what remains to be learned; the advancements in numerical models; current forecast techniques and their limitations; the impacts of hurricanes, with some notable examples from the past and a special chapter on Hurricane Andrew (1992); and finally a chapter on how to prepare for and mitigate losses from hurricanes. Although loosely tied together, the time line was not a rigid one and each chapter could essentially stand alone, similar to the format of The Weather Book. The proposal was given to a book agent who obtained a contract with Random House calling for a 
book of around 200 pages with a minimum of 16 pages of color for illustrations and photographs.

I wrote the great majority of the first draft of each chapter, frequently referring to the illustrations or photographs that I included in each chapter. I sent those draft chapters off to Jack, who would ask for clarifications and/or amplifications of some topics and then modify the writing somewhat to put it into a more narrative form. Jack also did considerable research and expanded on the early history of hurricane encounters and research. The first draft was completed in about 9-12 months, and if published in the full form with the illustrations and photographs would have been about a 300-page full-sized (6" by 9 ") book with 30-50 pages of illustrations and figures.

After reading the first draft of the book, the Random House editor said that he liked the material in the book, but suggested a fully narrative book with a rather rigid time line and a common narrative "thread" through the entire book, rather than somewhat stand-alone chapters. The narrative thread agreed upon was how people came to understand and forecast hurricanes. Two more iterations and a couple of years later, the book was published by Random House. Although this author is very pleased with the final text of the book, I am disappointed that it does not include several color illustrations and photographs. Apparently, the publishers felt that such a version of the book would be too expensive to reach the wide audience it was intended for. Fortunately, based upon all reviews of the book that I have seen to date, the lack of those illustrations has had minimal impact on its appeal. Descriptions like "outstanding in every aspect," "excellent," "wonderful," and "highly recommended" have been used in those reviews. Overall, the writing and publishing of this book was much more difficult than I thought it would be when I took on this project, and certainly would not have been brought to a satisfying and successful conclusion without the talents and perseverance of my coauthor.

Dr. Bob Sheets is the former director of the National Hurricane Center, Miami, FL, and a veteran of many hurricanes.

\section{Meteorological Instruments}

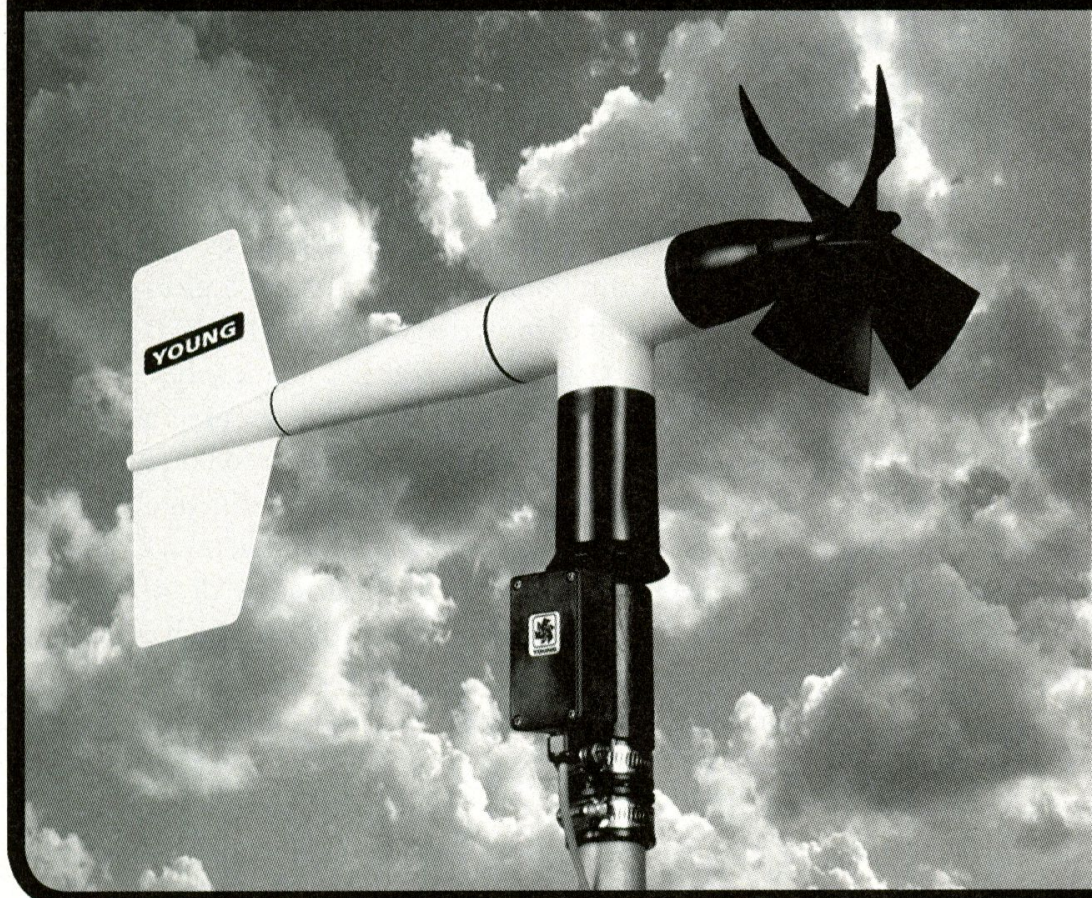

SENSORS TO MEASURE

- Wind Speed

- Wind Direction

- Peak Gusts

- Temperature

- Pressure

- Relative Humidity

- Precipitation

R.M. YOUNG COMPANY 2801 Aero Park Drive Traverse City, Michigan 49686 USA

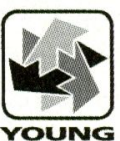

Tel: 231-946-3980

Fax: 231-946-4772

www.youngusa.com 
The following passage is excerpted from Reflections: A Memoir, pages 26-29, by David Atlas (2001, American Meteorological Society, 142 pp., hardbound, $\$ 70.00$, ISBN I-878220-46-2). Copyright (C) 200 I by the American Meteorological Society. All rights reserved.

was awarded a senior post-doctoral fellowship by the National Science Foundation in the early spring of 1959 to work with Frank Ludlam at Imperial College, London. My family_-including my wife, Lucille, nine-year-old Joan and five-year-old Robert-and I arrived on the "wrong" side of the narrow road from Southampton to our charming Trust house at Little Gaddesden. The hotel was close to the palatial estate, Ashridge House, which was the residence of the research group that Ludlam had assembled to study thunderstorms and hail. Our research headquarters was the Meteorological Office Radar Station at East Hill, Dunstable, which was under the direction of Bill Harper. ...

I joined the research team in the luxurious Ashridge House during the second month of the project there after my family settled in our residence in Sunningdale. Each evening we left our shoes at the door to be polished and each morning we had tea and biscuits delivered to our rooms. And Frank Ludlam whipped all of us at snooker after dinner each night.

In recognition of Ludlam's distinction in studies of clouds and storms, I had arranged a research contract from the Air Force Cam-

bridge Research Laboratories to support him and his students. In addition, in anticipation of the experiments to be conducted, I had organized the transfer of a 4.7-cm wavelength MPS-4 height-finder radar to Imperial College.

Following the field program, Ludlam had a tower constructed for the use of the MPS-4 radar at his Cheapside laboratory near Ascot. However, just before it was put into operation, a representative of the Queen ordered that the tower and radar be removed because it detracted from the view from Her Majesty's box at the Royal Ascot Racetrack.

The summer of 1959 was one of the warmest and clearest on record. We were rather naïve to plan a storm research program in England in any year. But luck again favored us-1959 turned out to be the ex- ception of the century. But what could we do while waiting for a storm?

Having remembered that Ryde [1946] did not extend his calculations of the cross sections of ice spheres beyond a diameter of one wavelength, I suggested that this was a great opportunity to validate and extend our knowledge of hailstone cross sections experimentally. ... For this purpose, Macklin made artificial 3-inch diameter hailstones by freezing water in tennis balls. These were then suspended in a lady's hairnet from a tethered balloon. About $150 \mathrm{ft}$ below the hailstone we suspended a 12-inch metal sphere as a reference standard target with known cross section. We could then tilt the beam alternately between the unknown hailstone and the standard target to measure the difference in cross section with accuracy comparable to that achievable in the best laboratories at that time. The only difficulty occurred when, unbeknownst to Ludlam and myself, Browning and Macklin amused themselves and confused us by substituting tomatoes for the hailstones. The measurements were made at three wavelengths simultaneously-3.2 cm with the TPS-10, $4.7 \mathrm{~cm}$ with the MPS-4, and $10 \mathrm{~cm}$ with the Ames type 13 height-finder radars.

We found that large ice spheres scattered about an order of magnitude better than water spheres of the same diameter. This was a surprise because we all nurtured the Raleigh scatter law that said that (small) ice particles scattered about one-fifth as well as equal water drops. Until then, the radar meteorological community had either forgotten or ignored the 1941 findings of Ryde [1946] that indicated that ice became a better scatterer than water at a diameter of about 0.6 wavelengths. I immediately sent a letter to Lou Battan at the University of Arizona informing him of our results. By sheer coincidence Ben Herman, then a doctoral student working on the scattering of infrared radiation by cloud drops (under Lou Battan), had programmed the Mie equations for the then state-of-theart IBM 720 computer. So, Lou suggested that Herman run the program for ice spheres at microwaves. I received the theoretical results within a couple weeks and plotted them along with the experimental measurements and returned them to Lou. In 
a tape-recorded message to me on October 8, 1986 (just three weeks before his death), he said:

. . and I must say, it was one of the big thrills of my scientific experience when I got your letter in which you had plotted your actual measurements against the curve. I remember thinking to myself; isn't this astounding, theory and measurements are in agreement. ...

Well, Lou's thrill could not have been any greater than that which Ludlam, Harper, Macklin, Browning, and I experienced 6000 miles away. It was just one of many examples of the fortuitous confluence of separately derived ideas that marks much of science. This work then became the motivation for an impressive list of studies conducted by Herman at Arizona and by my colleagues and myself at AFCRL [Atlas 1964; Battan 1973].
But much more was to be done at Dunstable while waiting for storm activity. We also conducted experiments to check Harper's claim that ring angels were due to starlings and not to some atmospheric phenomenon. To do this we sent Macklin and Browning out with walkie-talkies (at about 3:00 A.M.) to the tree roosts that Harper had identified as the sources of the ring angels. And lo and behold, just as the sun rose above the horizon, we saw the echoes [Rodger 1999]. As if on the signal of a wing commander, thousands of starlings took off simultaneously, spreading out in all directions, to have their insect breakfast in flight; they then formed nearly perfect circles, presumably in the innate knowledge that this was the way to fly in order to minimize the competition for their food. Observations such as these were to become the subject of the book Radar Ornithology by Eastwood [1967].

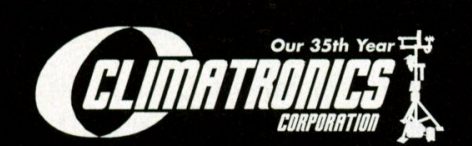

KNOWLEDGE. EXPERIENCE. DEPENDABILITY.

\section{INNOVATIVE COST-EFFECTIVE SOLUTIONS} FOR ALL YOUR METEOROLOGICAL NEEDS

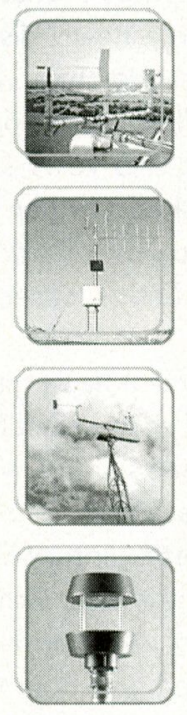

- Custom-Configured and Pre-Packaged Systems

- Wind Speed/Direction Sensors and Indicators

- Aspirated Shields, Towers \& Accessories

- Portable, Automatic, Self-orienting Weather Stations

- Integrated Systems \& Weather Station Networks

- ICAO, CAT II/IIIA Airport Weather Stations

- UHF/VHF Spread Spectrum Communication Systems

- NIST-Traceable Calibration \& Repair Facilities

- Fully Compliant with EPA, PSD, NRC, ANSI/ANS-3.11-2000, SARA Title III, CERCLA

\section{Design | Installation | Repair | Training}




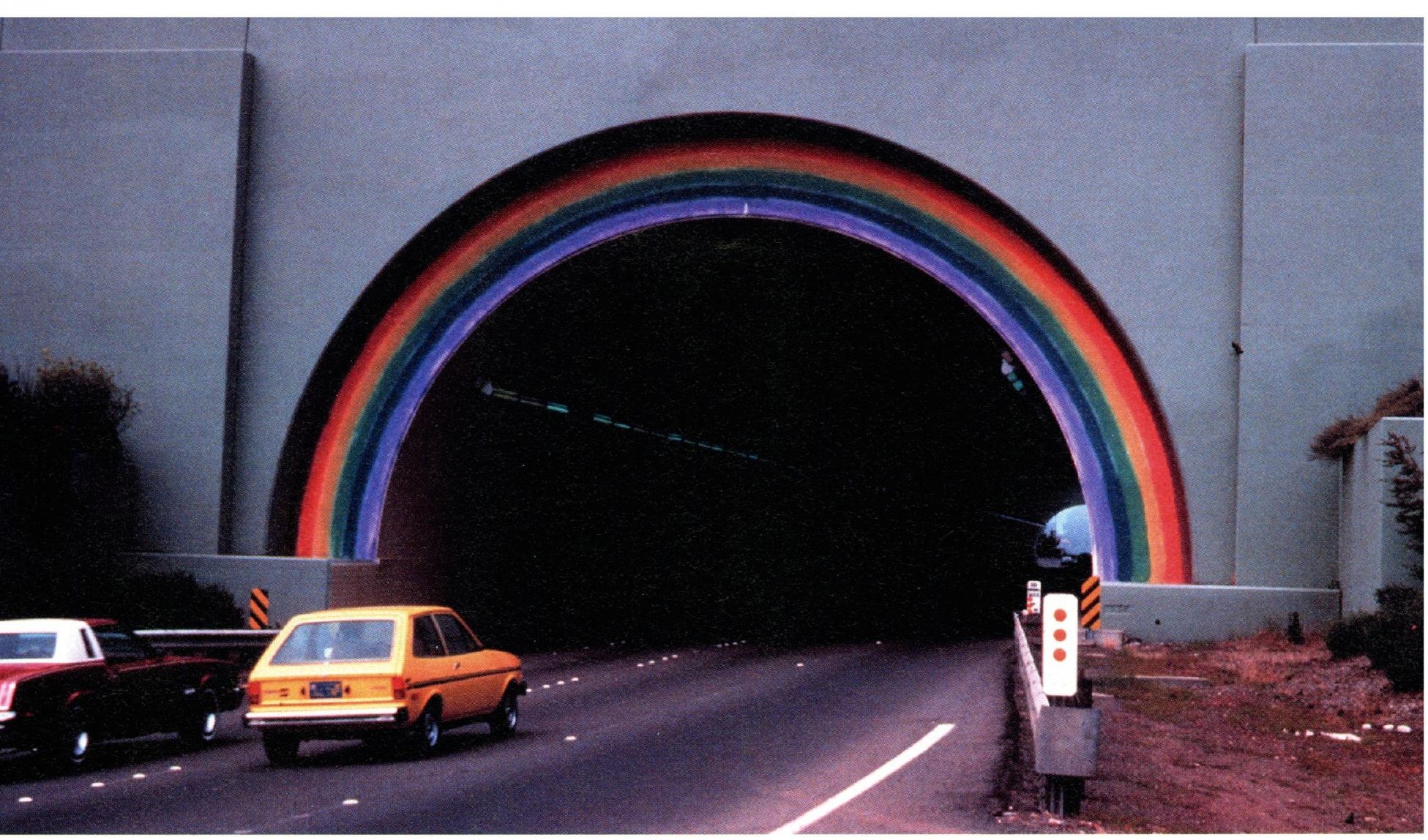

Cars entering a rainbow-painted tunnel just north of San Francisco in Marin County, California.

\section{BRIDGING THE RAINBOW GAP}

The following passage is excerpted from The Rainbow Bridge: Rainbows in Art, Myth, and Science, pages 309-31I, by Raymond L. Lee Jr. and Alistair B. Fraser (200I, The Pennsylvania State University Press, in cooperation with SPIE Press, 393 pp., hardbound, \$65.00, ISBN 0-27I-019778). Copyright (C) 2001 Raymond L. Lee Jr. and Alistair Fraser. Excerpted by permission. All rights reserved.

T

oday, the rainbow serves primarily as a visual shorthand for peace and natural beauty. As pleasing as these interpretations are, their very agreeableness makes them prey to trivialization. With triviality can come banality and a loss of meaning - in careless hands, the rainbow slides from visual shorthand to visual cliché. Furthermore, clichés feed on themselves, so that later generations of kitsch artists and their public learn from and value the rainbow clichés rather than the rainbow archetypes.

Consider a similar example from archaeology: our present-day stereotype of Neanderthals as simian brutes. Archaeologist Stephanie Moser shows how early twentiethcentury scientific opinion and prejudice combined with popular illustrations to create two completely different, but equally inaccurate, caricatures of these ancient humans. In 1909, French paleontologist
Marcellin Boule advised an artist for the French newspaper L'lllustration on the "accurate reconstruction" of a live Neanderthal, based on a newly discovered skeleton. Boule's vision of Neanderthals was truly monstrous, as evidenced by L'lllustration's picture of a massive, stooped simian. Yet two years later, the Illustrated London News published another scientifically sanctioned image that showed a markedly human (and European) reconstruction based on the very same skeleton.

Both images of the Neanderthal had more to do with the ideological agendas of their scientific advisers than reality, yet it was Boule's brute who lived on in the public consciousness. Why? One suggestion is that Boule's early twentieth-century European public was still distinctly uncomfortable with its new Darwinian role as descendants of lower primates. Just as today's public seeks unalloyed beauty in the rainbow, so Boule's public looked for unambiguous brutishness in an uncomfortably recent ancestor. Later generations exposed to Boule's stark vision of $\mathrm{Ne}$ - 


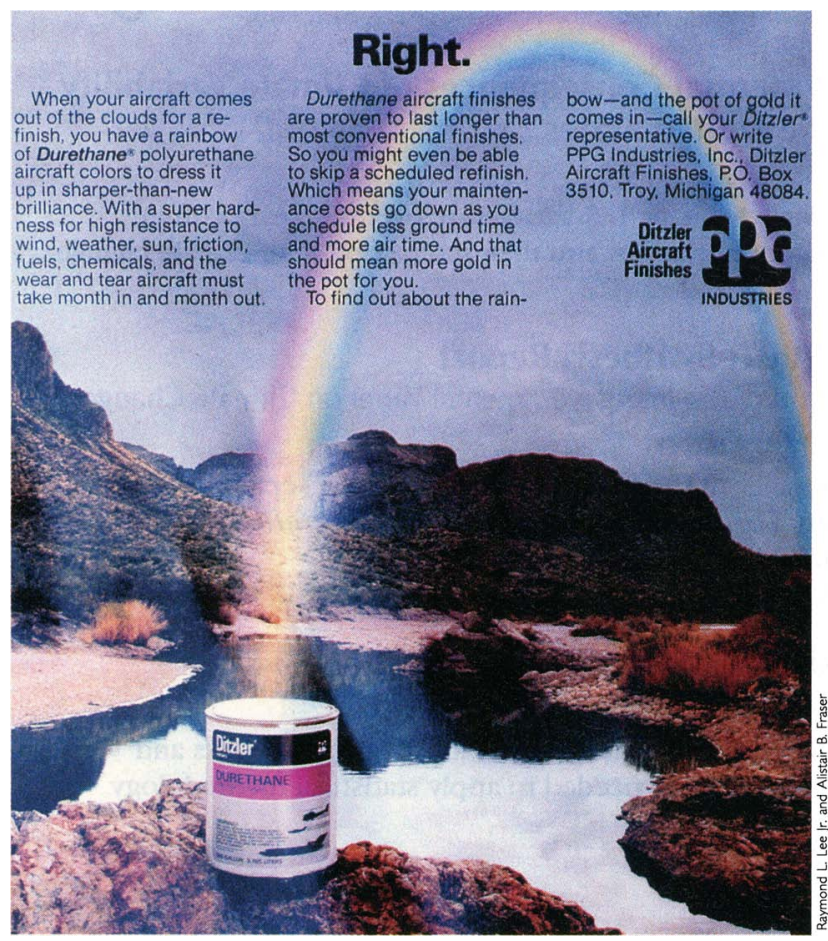

anderthals would likely find it more compelling than a less dramatic yet scientifically balanced image.

In fact, popular readings of the rainbow and $\mathrm{Ne}$ anderthals nicely define polar opposites in our views of nature. Whereas Neanderthals supposedly embody our tangibly animalistic side, the rainbow is made a proxy for our intangibly spiritual side. Both clichés have almost nothing to do with the realities of either Neanderthals or rainbows, yet they are remarkably durable. That the optimistic, spiritual rainbow cliché is nothing more than cultural parochialism is evident in the very different roles for the rainbow that we find throughout the world. . .

In fairness, our clichés do serve the purpose of simplifying a complex world. If every natural phenomenon we encountered in daily life demanded its own thorough, even-handed explanation, we probably would be immobilized by instruction. In addition, most of us have had the frustrating experience of having a cherished icon demystified and rationalized by the earnest explanations of others. Is that our agenda with the rainbow? No, far from it. Indulging in fantasy for its own sake is one of life's great pleasures, and rainbow fantasies are no exception. However, being unable to distinguish between rainbow fact and fantasy is no asset. Being able to make that distinction is our goal here.

(See a review of this book on page 762 .)
Magazine advertisement for "pot of gold" aircraft paint from Ditzler Aircraft Finishes. (left)

\section{Rainbow motel sign, Swift Current, Saskatchewan,} 1980. (below)

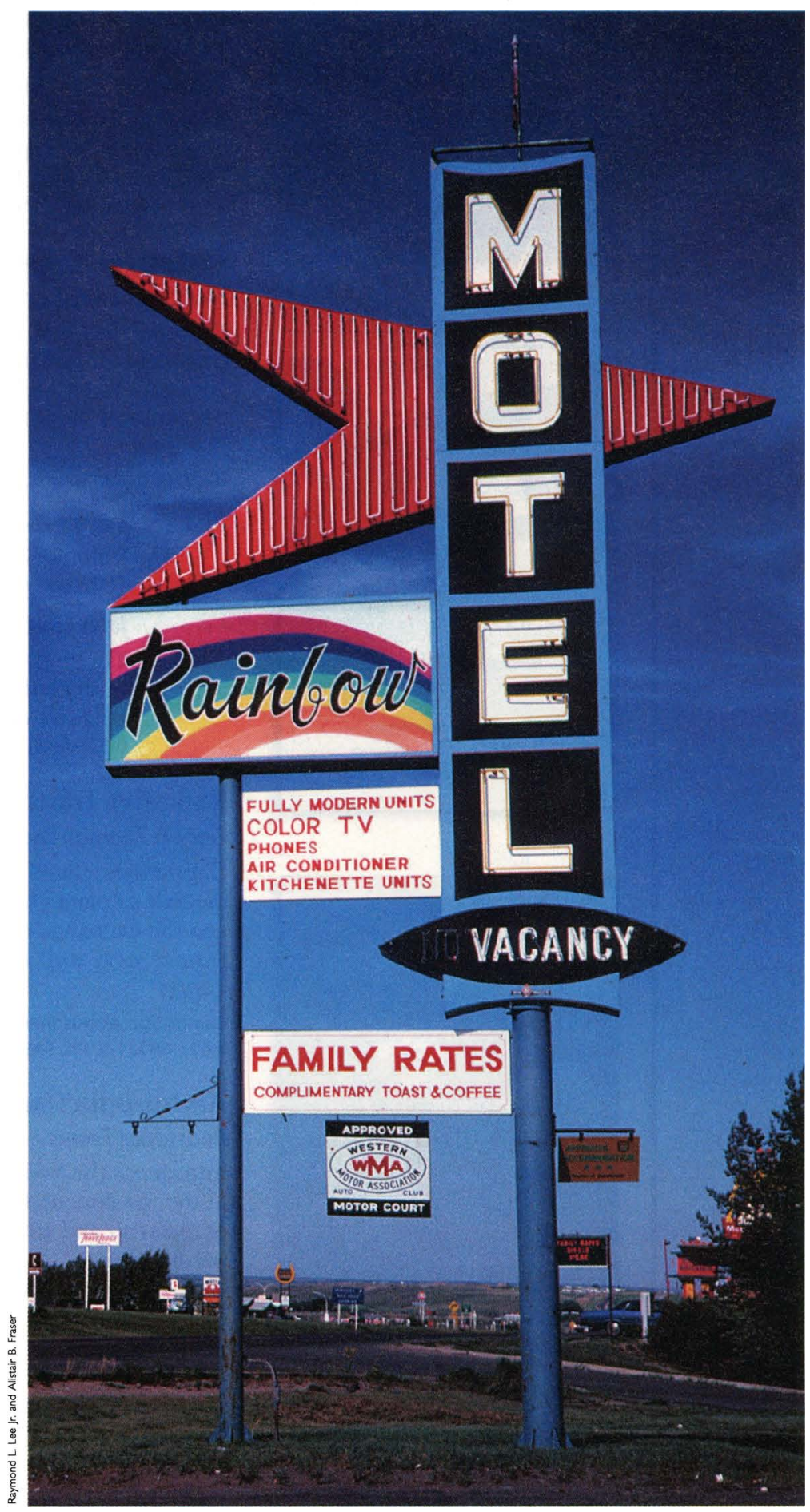




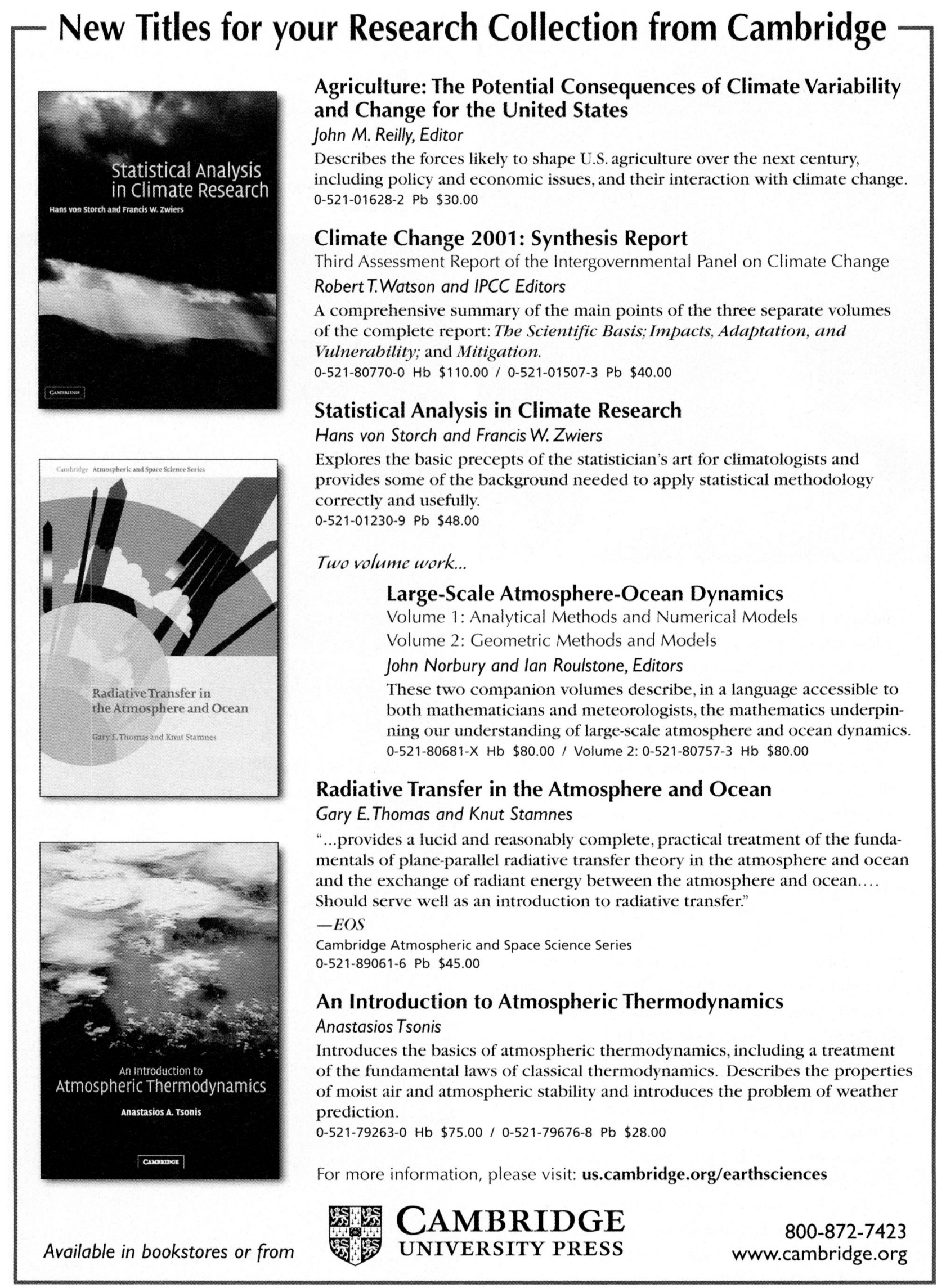




\section{THE COMING STORM: EXTREME WEATHER AND OUR TERRIFYING FUTURE} Bob Reiss, 200I, 323 pp., \$24.95, hardbound, Hyperion, ISBN 0-7868-6665-9

W e humans are programmed to recognize patterns. Sociobiologists argue that this penchant for pattern recognition gave us an evolutionary advantage: it was better to think you saw a tiger in the bush that turned out not to be there than to miss one that was. When extended from the space to the time domain, our obses-

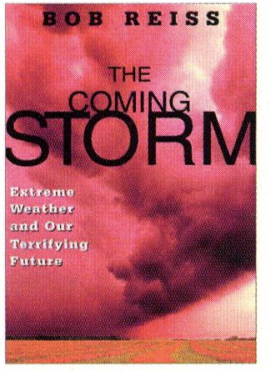
sion with patterns becomes a quest for causality. Statisticians know that the three suicides in our town this year are very much within the normal fluctuations of suicide rates; the rest of us struggle to understand what could have gone wrong.

Chaos makes mockery of our desire to ascribe a cause for every effect. Was that terrible hurricane that hit Florida caused by the Bermuda high? By a group of thunderstorms off the African coast last week? By the easterly wave over the Sahel a few days earlier? By the little Somalian girl who, playing in the sand, kicked off a dust devil a few days before that? In a chaotic system, the occurrence of any particular event at a given place and time can be ascribed to a very unlikely coincidence of innumerable prior events. Had any of them been the slightest bit different, the event in question would not have occurred as it did. Still, we are insistent: Surely, professor, with all those computers and satellites at your disposal, you can tell us what caused the extraordinarily cold weather in Boston this winter. Just tell us: Was it El Niño? In frustration, we too often give up, pin the blame on the jet stream, and marvel that our inquisitor seems satisfied by the answer.

Arguably, the "100-year" events cause the most trouble, being the most frequently occurring events that are still, on average, outside the memory of the oldest living inhabitant. "Never seen anything like it," "I've lived here all my life and it's never been this bad," and such phrases invite the non sequitor that climate must be changing. Since the 100 -year event is nearly always locally defined-a flood, a storm, a cold wave-there are plenty to go around globally in any given year, providing abundant fodder for the cannon of the apocalyptically minded.

Real trouble begins when we fold human responsibility into the mix. Through most of history we blamed ourselves and one another for the likes of droughts, plagues, and storms. Clearly the gods were displeased and were punishing us for our sins. We made resolutions, brought forth offerings, shed a little blood. But civilization does advance, and today, instead of virgins, we sacrifice mere reason to clear our consciences.

In The Coming Storm, Bob Reiss plays skillfully on our tendency both to see a pattern in extreme events and to hold ourselves accountable for them. The book consists of two interwoven narratives: one describes the devastating effects of natural disasters on people's lives; the other recounts the scientific research and politics leading up to and just beyond the Kyoto Protocol. The intent of the author is clearly to blame global warming for what he sees as an increased occurrence of natural disasters. He uses "never seen anything like it" coupled with folk wisdom to establish the link in the reader's mind. After a deeply moving account of the death of a young man in a tornado, we hear from the man's mother: "Well, I know what caused the tornado we had in Nashville, and it was the greenhouse effect." Meanwhile, the author assures us that "if greenhouse theorists are right, his death is a harbinger of the kinds of tragedies that will occur with greater frequency in the future."

Problem is, greenhouse theorists are saying no such thing. According to the most recent report of the Intergovernmental Panel on Climate Change (IPCC), "No systematic changes in severe local storms, such as tornadoes or hail are evident" in the record. Climate science has not advanced far enough to make theoretical predictions about changes in the incidence or intensity of tornadoes.

Another effective technique is to start with a legitimate scientific result and generalize it well beyond what the science itself supports. We hear about Tom Karl's fascinating work on changing distributions of hydrological and temperature extremes, showing both a statistically significant increase in the incidence of high intensity precipitation events in the United States and a decrease in the diurnal range of temperature over continents worldwide. But Reiss bootstraps this into the notion, stated already in the prologue, that global warming is "increasing incidents of hurricanes, droughts, windstorms and tornadoes." With the possible exception of droughts, this is just plain false. In the case of hurricanes, theory does suggest that in- 
tensity should increase with tropical ocean temperature, but the amount of increase predicted to have occurred in the last century would be undetectable, and there is no evidence of any increase in the records so far.

Reiss evidently subscribes to what might be called the Schneider Principle. Some years ago, Stephen Schneider said in an interview that to motivate political action, scientists "have to offer up scary scenarios, make simplified, dramatic statements, and make little mention of any doubts that we might have. . . Each of us has to decide what the right balance is between being effective and being honest." Quite apart from the ethical issues this attitude raises, there is the practical problem that, once having been caught crying wolf, the credibility of the scientist is compromised. When and if the real wolf shows up, a jaded public will have ceased listening. There is scientific evidence for anthropogenic climate change; to spike this with false or exaggerated claims can only desensitize and distract from the real issues.

Reiss is at his best when recounting the horrors of natural disasters. His moving story of the death of an English schoolgirl, too tall to hide under her desk when the roof of her school collapses in a windstorm, should be required reading for all weather forecasters and emergency personnel. The Coming Storm also offers valuable, if depressing, insights into the politics of global warming. We hear of Senator Tim Wirth's maneuvering to schedule Jim Hansen's 1988 testimony during a heat wave and to prevent skeptics from testifying, the coal and energy companies' brutal attack on Ben Santor's integrity during a 1996 hearing, and Al Gore's failed attempt to get Ted Koppel to smear Fred Singer by associating him with the Moonies and Lyndon LaRouche. We also hear about a coalition of developing countries at the Kyoto meeting who, while arguing for a $35 \%$ reduction of greenhouse gas emissions by the industrialized nations by 2020, wanted OPEC countries reimbursed for the lost income should the protocol come into force. We do not hear that $80 \%$ of the electrical power generated in France is nuclear, nor is the environmental movement held to account for its effective veto of nuclear power in the United States.

What little meteorology can be found in The Coming Storm is dealt with cavalierly. To form a cold front, "a midlevel jet stream would keep air close enough to the earth so it would collide with warm air near the ground." We are told that pressure decreases upward because "gravity is weaker the higher you travel from earth." A quick reading by any undergraduate meteorology major would have caught these and similar errors.

One might well ask why a respected journalist who has worked for The Chicago Tribune, The Washington Post, and The Smithsonian, among others, thinks it is alright to play fast and loose with scientific truth. The answer, I think, has to do with our outdated attitudes toward education. MIT, where I work, is an in-

\section{NEW PUBLICATIONS}

INTERNATIONAL RELATIONS AND GLOBAL CLIMATE CHANGE

Urs Luterbacher and Detlef F. Sprinz, Eds., 2001, 343

Pp., $\$ 25.00$, paperbound, The MIT Press, ISBN 0-262$62149-5$

Climate change is a truly global topic, and as a result is highly political.

Despite some agreements, such as the Kyoto Protocol, there remains much progress to be made between nations with regard to the complex issues connected to climate change. This book provides a broad-based analysis from many angles-hypothetical, conceptual, technical-of the cooperation necessary to confront these issues. It explores legal matters, world trade, domestic politics, international negotiations, and numerous other subjects. The book takes an unbiased tone-its goal is to educate readers on the key issues of global environmental policy, rather than deliver opinions on which policies might be most effective.

A WORLD OF WEATHER: FUNDAMENTALS OF METEOROLOGY (THIRD EDITION) Lee Grenci and Jon Nese, 200I, 550 pp., \$55.95, hardbound, Kendall/Hunt Publishing, ISBN 0-7872$7716-9$

This book is intended for use in an introductory-level college meteorology class. It first introduces basic concepts of meteorology (radiation, temperature, precipitation, etc.) before discussing the details of atmospheric science, including hurricanes, cyclones, and tornadoes. This updated edition contains a considerable amount of new material, including new chapters on weather forecasting and numerical weather prediction and a novel examination of the cyclone model. It includes laboratory exercises and other material that encourages hands-on activity.

SCIENCE INTO POLICY: GLOBAL LESSONS FROM ANTARCTICA Paul Arthur Berkman, 2002, 252 pp., $\$ 59.95$, hardbound, Academic Press, ISBN 0-12-091560-X

Antarctica is a prominent example of the potential of global cooperation. Since the signing of the 1959 Antarctic Treaty, over 40 countries have studied the continent's climate and environment in an amicable partnership. The book integrates an examination of this governmental union with an extensive 
stitute of science and technology, yet all undergraduates must take at least eight semesters in the humanities. By contrast, Yale, whose academic requirements are said to "represent a consensus of what educated men and women believe to be the values and goals of a liberal education," requires only two semesters of science. Not until liberal arts programs divest them- selves of that last vestige of the old boy attitude-that "gentlemen do not do science"-can we expect better fare than The Coming Storm.

- Kerry Emanuel

Kerry Emanuel is a professor of meteorology at the Massachusetts Institute of Technology.

\section{DISTRIBUTED HYDROLOGIC MODELING USING GIS}

Baxter E. Vieux, 200I, 293 pp., \$89.00, hardbound, Kluwer Academic Publishers, ISBN 0-7923-7002-3

$\mathrm{F}$ or years, hydrologists have been faced with the problems of dealing with difficult and vast spatial information that forms a basis of distributed modeling at the basin scale. Because of most people's fear of information processing tools, many texts have tended to downplay these tools, thereby undermining the strength of informatics in handling complex hydrological problems. Those that have dealt with the information tools have generally resorted to general or geographical solutions. In this book, the author has redressed this situation, using advances in Geographic Information Systems (GIS) and spatial statistics to show that the spatial information and its processing tool-GIS - can be easily used, even by those who lack a rigorous GIS background.

Distributed hydrologic modeling and GIS are two academic fields independently proposed many years ago, and in recent years these two fields have become more and more connected. Apart from development in theories of distributed modeling, the application of GIS to the modeling of river basin hydrology has formulated one of the major directions in hydrological sciences. This book provides readers with thorough and practical methodology and examples: how to produce spatial inputs to a model, how to parameterize a distributed model by using GIS, and how to fulfill these on the GIS interface.

The book consists of 11 chapters, a useful glossary, an index, and an illustrative appendix. Each chapter begins with a discussion or introduction of the physical or methodological concepts related to one topic. This is generally followed by development and interpretation of method, data processing, or applications. A conclusion and a list of references complete each chapter. All symbols and technical terms are defined when introduced in the text, and a detailed glossary discussion of earth system science and Antarctica's role in the preservation of global resources. The marriage of policy and science in Antarctica is emphasized as a prime example of the international collaboration necessary to sustain life on earth.

\section{OF THE: EARTH, SPHERES, AND CONSEQUENCES}

Dr. Michael S. Hamilton, 200I, 287 pp., $\$ 24.95$, hardbound, Vantage Press, ISBN 0-533-134I4-5

What are the natural forces that influence the way we live on earth, and in what ways do these forces interact? This book examines the scientific processes of the various aspects of our environment, including geologic, atmospheric, hydrologic, and radiative components, and gives in-depth explanations of their interrelationships. Hurricanes, earthquakes, floods, and other disasters are discussed, giving emphasis to the impact nature can have on human life. Anthropogenic factors are also explored, as is the mitigation of these factors. This work includes almost 200 illustrations and-although technical in nature-is written with the layperson in mind.

\section{APPLICATIONS OF THE} CONSTELLATION OBSERVING SYSTEM FOR METEOROLOGY, IONOSPHERE AND CLIMATE (COSMIC)

Lou-Chuang Lee, Robert Kursinski, and Christian Rocken, Eds., 2001, 380 pp., $\$ 119.00$, hardbound, Springer-Verlag, ISBN 962-430-135-2
The Constellation Observing System for Meteorology, lonosphere, and Climate (COSMIC) is a joint venture between the United States and Taiwan intended to improve global weather forecasting. Scheduled to begin in $\mathbf{2 0 0 5}$, COSMIC will consist of eight low earthorbiting satellites that will convert Global Positioning System symbols into data on precipitation, temperature, and pressure. This book discusses various aspects of the system and explores its potential usefulness, not only in forecasting, but also in climate-change research and space weather observation. It also includes descriptions of the tiny ionospheric photometer and the tri-band beacon transmitter, two other instruments to be used in conjunction with COSMIC. 
is provided at the end of the book, which will be convenient for some readers. The typeface of equations and tables is easy to look at.

Chapter 1 outlines the complete contents of the book. Purposes, characteristics, and merits are briefly explained by the author. Chapters 2-11 examine specific topics in detail. Chapter 2 discusses GIS data sources and structures that hydrologists might not be familiar with. General concepts and terminology of data maps, data type, and presentations are defined and interpreted. These concepts are fundamental to GIS users. Chapter 3 centers around surface generation, the creation of spatially distributed data from limited point datasets. Three major generators (inverse distance weighting, thin splines, and kriging) are explained and illustrated. Surface generators are needed to produce rainfall inputs and parameters' distribution. Chapter 4 discusses an important problem on data resolution and spatial variability - that is, what is a sufficient resolution to capture spatial information? A theory of information content entropy and resolution effects on digital elevation models (DEMs) is presented.

Chapter 5 gives a good review and summary of theories and modeling methods relating to infiltration, one of the core problems in hydrology. Examples are also given on how to obtain distribution of some infiltration parameters by using soil maps and other spatial data sources. A key parameter of hydraulic roughness is discussed in chapter 6 , with many ex- pressions provided and applications to a river basin introduced. Chapter 7 deals with a basic and important topic: the drainage network and topography. This topic may show the greatest connection between hydrology and GIS. Extraction of the drainage network from the DEM is reviewed and fractal dimensions of the network and the effects of DEM grid cell size on drainage length and slopes are discussed and illustrated, showing that distributed parameters are dependent on grid cell size. Chapter 8 introduces radar estimation of precipitation, a driving input to the distributed model, and examples of applying WSR-88D radar to get spatial surface rainfall are shown.

Chapter 9 presents a specific distributed model called r.water.fea, as well as its mathematical analogy and numerical algorithms. This model accesses the GIS GRASS map database for various parameters. Formulation of the model, a steady-state example, presentations of the drainage network and spatial parameters, and implementation of the model within the GIS frame are examined. The calibration methods of distributed models, especially the adjoint automatic calibration, are described in chapter 10 , and some initial application to the Illinois River Basin is introduced. In chapter 11, case studies with distributed modeling are presented. The DEM, channel, parameters, rainfall, and discharge in the Illinois River Basin are described, model calibration results are illustrated, and the parameter's sensitivity to spatial

\section{NEW PUBLICATIONS}

\section{SCATTERING: SCATTERING AND INVERSE SCATTERING IN PURE AND APPLIED SCIENCE (TWO-VOLUME SET)}

Roy Pike and Pierre Sabatier, Eds., 2002, 1831 pp., $\$ 850.00$, casebound, Academic Press, ISBN 0-12$613760-9$ (set)

This boxed set provides a comprehensive and up-to-date analysis of the phenomenon of scattering-the interaction of particles that results in a change of direction and energy. Encyclopedic in its size and scope, this work is first of its kind to provide such extensive information on scattering theory as it relates to acoustics, elastodynamics, electromagnetics, and quantum mechanics. It also includes discussions on scattering in oceans and the atmosphere, as well as sections on nuclear physics, $x$-ray scattering, mathematical theories, and numerous other topics encompassing many disciplines.

\section{CIRRUS}

David K. Lynch et al., Eds., 2002, 480 pp., $\$ 90.00$, hardbound, Oxford University Press, ISBN 0-19513072-3

An outgrowth of a 1998 conference held in Baltimore, Maryland, this title brings together the latest research on cirrus clouds, which until recently had received little attention. Contemporary studies have shown that these clouds can have an effect on climate change, and the book explores this subject, focusing on the interrelationships of cirrus clouds with the global radiation budget and remote sensing systems.
Many other cirrus topics are addressed as well, including their history and definition, structural and optical properties, evolution and dissipation, radiative transfer, and anthropogenic effects.

THE WEATHER WIZARD'S 5-YEAR WEATHER DIARY

Mary Hunt, 2001, 400 pp., \$13.95, spiralbound, Algonquin Books, ISBN 0-94557-585-8

For those who want to keep track of the daily weather from their own home, either for fun or as an aid to their work, this title is a convenient resource for cataloguing climate trends. It allows for daily entries for up to five years and also includes a multitude of facts, statistics, and information relating to the weather. 
variability and the model's sensitivity to resolution are checked and explained. Chapters 9, 10, and 11 combine to explain how to set up a distributed model and how to calibrate and apply it by using GIS. At the end of the book, a glossary of technical terms and an appendix (user manual) for the ArcView environment module arc.water.fea (an extension of r.water.fea) are provided, making the book more referential.

Although this book is generally concerned with surface runoff and flood periods, the conceptions and methods, as well as the method of utilizing GIS for distributed models, are remarkably useful. Readers are encouraged to experiment with the introduced model and their own models in order to produce a proper interface between the models and GIS frame. Careful study of this excellent book will help achieve understanding of GIS-based distributed modeling, and it is highly recommended to students, teachers, researchers, and engineers involved in hydrology, water resources, and environmental sciences.

$$
\text { - Huaxia Yao }
$$

Huaxia Yao is a research scientist at the Faculty of Science, The University of Western Ontario, London, Canada. He was a professor in Japan and China.

\section{OBSERVATION OF THE EARTH AND ITS ENVIRONMENT: SURVEY OF MISSIONS AND SENSORS (FOURTH EDITION)}

Herbert Kramer, 2002, I540 pp., \$199.00, hardbound, Springer-Verlag, ISBN 3-540-42388-5

0 $\mathrm{f}$ all of the books in my office, this is the one that I refer to most frequently. Anyone working in the field of remote sensing will eventually need the answers to questions such as, "What is the instrument complement of UARS?" or "What is the spatial resolution of EROS-A1?" Even in this age of online resources, the best and fastest way to answer those questions is to consult this book. Herbert Kramer has provided a comprehensive and up-to-date compendium of spaceborne missions that are designed to perform not only earth remote sensing, but also upper-atmosphere and ionosphere sensing, near-earth space environmental monitoring, and technology demonstrations. Thus, the word "environment" in the book title should be interpreted in the broadest possible sense. Nearly all relevant spaceborne missions, past and present, and those that appear to be reasonably firmly planned, can be found. The encyclopedic portion of the text on spaceborne missions totals over 1000 pages, and that alone would compose a unique
THE GLOBAL WARMING DESK REFERENCE

Bruce E. Johansen, 2002, 353 pp., $\$ 70.00$, hardbound, Greenwood Press, ISBN 0-313-31679-1

Intended for undergraduates, this is an accessible book that gives a comprehensive overview of the widely discussed topic of global warming. It presents evidence of the problem by examining research in areas (e.g., Antarctica, Honduras, northern Canada) around the world where global warming effects have been studied. It also devotes a chapter to the theories of scientists who do not believe the greenhouse effect is a legitimate scientific concern. The book concludes with a discussion of possible resolutions to the global warming problem. It also includes an extensive bibliography.
THUNDERSTORMS ACROSS THE NATION: AN ATLAS OF STORMS, HAIL, AND THEIR DAMAGES DURING THE 20TH CENTURY Stanley A. Changnon, 2001, 93 pp., $\$ 5.00$, paperbound, Changnon Climatologist, ISBN 0-963I8I-4-9

Containing numerous photos, graphs, and maps, this work explores the climatology and history of thunderstorms, with particular attention paid to their patterns and their temporal variations. It incorporates significant new data that only recently became available. Some topics covered include the causes, frequency, and location of thunderstorms, incidences of hail and lightning, and damage caused by these storms. The author has been researching thunderstorms and hail for 50 years.
UNDER THE WHIRLWIND: EVERYTHING YOU NEED TO KNOW ABOUT TORNADOES BUT DIDN'T KNOW WHO TO ASK Jerrine Verkaik and Arjen Verkaik, 200I, 224 pp., \$21.95, paperbound, Whirlwind Books, ISBN 0-968153-74-7

The authors of this title are professional photographers as well as veteran storm-chasers, and here they provide a comprehensive, non-technical overview of tornado science, safety, and damage. The book discusses storm structure and development, damage mitigation, poststorm issues (trauma, insurance, etc.) and many other topics. A key feature of this book are the numerous full-color photographs, which show the spectacle of these storms while also offering instruction on reading the skies. 
reference text. But there is much more to this book. The first chapter includes an exhaustive 157-page "short" history of earth observation. The section titled "Reference Data and Definitions"

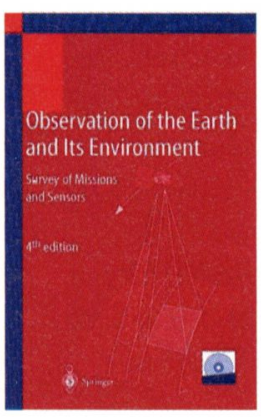
could itself be a useful 110-page guidebook on remote sensing technologies. And in keeping with the theme of choosing modest titles, the 84page section of "Acronyms and Abbreviations" is far more than that. It includes excellent descriptions of the functions of many remote sensingrelated organizations, useful tables, and concise histories of the organizational name changes and mergers that many companies around the world have undergone over the decades. I do not know anyone in this field who is not confused by those changes, and this summary is very helpful.

The portion of the book in which the spaceborne missions and sensors are detailed is both broad and deep. In parts $\mathrm{A}$ through $\mathrm{N}$, the missions are organized into areas such as "Atmosphere/Radiation/Aeronomy Missions," "Commercial Imaging Satellites," "Data Collection Systems," "Earth Observation/Monitoring Missions," "Meteorology-GEO Missions," "Space Science/ Solar-Terrestrial Missions," and so on. The mission descriptions include in-depth information about the sponsor, the spacecraft, the hardware providers, and each individual sensor (instrument). Much information that is difficult to find elsewhere is presented in an organized fashion. For instance, there is a full description of the extensive sensor complement on the Russian Priroda module that was part of the Mir space station. There is a complete description of the Indian IRS series of satellites and their sensors. There is a table of the complete history of NOAA's weather satellites and sensor complements. There is even an inclusion of the odd little fact that the Russian Okean$\mathrm{O}$ satellite series is a follow-up to the Okean-O1 series.

The entire contents of the book are also provided on a CD-ROM. The CD also contains a 327-page survey of airborne sensors. The author states that most of his effort in updating this book since the third edition was published in 1996 was spent on the spaceborne missions, since that is where more of the changes occurred. But the information on airborne missions is quite useful and detailed. Remarkably, there is also an 80-page summary of remote sensing field campaigns. To my knowledge, this information has not been gathered in any other single resource.

This is the fourth and unquestionably the best (and quite possibly the last) edition of this book. Some of the aspects of my professional life require that I maintain cognizance of past, present, and planned earth remote sensing missions worldwide. I can thus attest to the quality and thoroughness of this book. Given the freeze date of mid-2001 on the information, nearly every mission that merits discussion is included. I could only identify two omissions that probably should have been included-namely, ARIES and AVStar. I personally know Herbert Kramer to be a tireless and dedicated individual, and it takes someone with those attributes to see a task like this to completion. In the interest of full disclosure, it should be stated that I provided the author with certain historical and mission information, definitions, technical and organizational advice, and proofreading. My opinion of the past editions was such that I was happy to donate my personal time to help with this latest effort.

No book of this magnitude and scope can be perfect, however, and this one is no exception. It is sorely in need of an alphabetical index of missions. The index of sensors is a help, but if you were looking for the mission SUNSAT, you probably wouldn't know the names of the sensors on board. The list of acronyms and abbreviations has selected page references, but not all mission names are acronyms and locating the others can be difficult. Additionally, the book often presupposes a detailed level of knowledge in the reader. For example, you will find the German BIRD fire-and-hot-spot monitoring mission under "Satellite Emergency Services and Environmental Monitoring" rather than "Earth Observation/Monitoring Missions." You will find the South African SUNSAT under "University/Student-Developed Satellites \& Payloads." And, somewhat inappropriately, you will find the sea surface-winds QuikSCAT mission under "Atmosphere/Radiation/Aeronomy Missions."

There are also various technical problems with the book. Pushbroom and whiskbroom scanning are discussed under "Observation Schemes" on pages 12101212 and in the glossary on page 1355 . While the figures are clear, the discussion of whiskbroom scanning is inaccurate, confusing, and poorly organized. The discussion of spatial resolution on pages 1235-1236 refers only to the geometrical projection of a detector onto the ground (IFOV). It does not discuss the role of integration time and the resultant smear of that projected footprint. Nor does it discuss the role of Ground Sample Distance, which can be found separately in the glossary on page 1339 , nor the Modulation Transfer Function, which can be found on page 


\section{REANALYSIS}

Looking back at "News and Notes" in the Bulletin of February 1952:

Fishing WeAther?

Dr. George W. Bennett, Aquatic Biologist, State Natural History Survey Division, Urbana, III., writes:

"A number of years ago Dr. David H. Thompson, formerly with the Natural History survey, obtained a twelve-year creel census from a private fishing club located near St. Louis. As the record was a complete tabulation of all the fish caught from the club lake, Thompson believed it would be worth while to spend the necessary time to check the catch records against changes in barometric pressure as recorded at the St. Louis Weather Station. After about six months of work, Thompson came to the conclusion that there was no correlation between fish catches and highs, lows, or changes in barometric pressures. Because he could show no correlation whatever, he never published a formal report of this work. During the twelve years in which the catch record was made, fishermen were not aware of the barometric theory so were not influenced in their selection of fishing time by changes in the barometer."

Dr. Edwin L. Cooper, Institute for Fisheries Research, Michigan Department of Conservation, Ann Arbor, Mich., writes:

"From records obtained on more than four thousand fishing trips scattered over every day of Michigan's I35-day trout season for two years, little evidence can be found in support of the predictions of various fishing calendars ... or of predictions based on changes in barometric pressure.... Fishing was about as good when the barometer was falling as when the barometer was rising."-Michigan Conservation, May-June I95I, p. 4.

James G. Sieh and John Parsons calculated the average catches per hour on a rising, falling, and steady barometer.

"There is a suggestion of increased activity of the yellow bass during periods of a rising barometer and decreased activity during periods of a falling barometer [and] the opposite... with the yellow perch ... [but] the differences were not statistically significant. Walleye and bullhead activity appeared almost constant during the three periods of barometric tendency.

"An attempt was made to correlate wind direction, wind velocity, sky cover or cloudiness, and thundershowers or rain with fish activity. The data indicated that none of these variables could be correlated with movement phenomena."-Excerpts from "Activity Patterns of some Clear Lake, lowa, Fishes," lowa Acad. of Sci., v. 57, 1950, pp. 515-5 I6.

-Bull. Amer. Meteor. Soc., 33, 47.

1351. The other quibbles I have with the book are relatively minor. Some have to do with an occasional incorrect usage of terms, such as the use of "timeliness" when "refresh" is intended-in the definition of "In-situ soundings" on page 1342. Less obvious flaws relate to the book's omissions. A definition of "beamsplitter" is found on page 1324, as a device that splits a light beam, but no definition is found for "dichroic beamsplitter," which is a device that is frequently used for spectral separation in multispectral imagers.

But those criticisms pale beside the overall value of the book. This book is a tour de force. It is an indispensable reference book that belongs on the bookshelf of every serious practitioner of remote sensing science and technology, and I have already enthusiastically recommended it to colleagues around the world. In my estimation, it is a unique resource and has my very highest recommendation.

$$
\text { -David L. GLACKIN }
$$

David L. Glackin is a remote sensing scientist with The Aerospace Corporation, Los Angeles, California, where he is on senior staff. He has authored over 70 publications in remote sensing, solar physics, stellar atmospheres, geophysics, and image processing; given many invited talks and chaired sessions at international conferences; and worked on remote sensing physics, phenomenology, sensor concepts, sensor design, and data interpretation for earth environment and solar applications across the spectrum from $X$-rays to microwaves. He is also the principal author of the book Civil, Commercial and International Remote Sensing Systems and Geoprocessing. 


\section{THE RAINBOW BRIDGE: RAINBOWS IN ART, MYTH, AND SCIENCE}

Raymond L. Lee Jr. and Alistair Fraser, 200I, 393 pp., \$65.00, hardbound, The Pennsylvania State University Press/SPIE Press, ISBN 0-27I-0I977-8

1 n January 1982, Alistair Fraser delivered a riveting invited lecture containing the kernel of The Rainbow Bridge. Yet finding a publisher for this magnificent, broad-based, and lavishly illustrated work that bridges the chasm between science and art turned out to be almost as difficult as finding a pot of gold at the end of the rainbow. Somewhere midstream, Raymond Lee joined his mentor Alistair as a graduate student in meteorology with a background in art history and carried the work through to its completion. In the authors' words, they have written "an illustrated survey of the rainbow's place in science, mythology, and art, not an exhaustive monograph on one of those themes."

The rainbow is one of humankind's premier symbols, permeating our myths, art, and literature. It serves as a perpetual source of inspiration for aspiring atmospheric scientists and a cornerstone problem in the history of science. Covering such an extensive field, as the authors have done superbly, requires polyglot abilities. Both authors have made fundamental contributions to our understanding of rainbows and have at the same time become historians of the first class. Reading The Rainbow Bridge is a cultural and scientific happening.

Chapter 1 covers the mythological roots of the rainbow, showing how it has been depicted in ancient times from rock paintings in the Sahara to Greek pottery. The mythological themes often repeat in widely separated cultures. One common notion was that the rainbow was a bridge to the gods. In the Bible, it is a guarantee of safety-the world will never again be flooded-but in many cultures it has taken on a decidedly pessimistic tenor, perhaps because it precedes or accompanies violent weather. The rainbow was often portrayed as a serpent or snake, and was sometimes assumed to have the power to change the sex of a child who got too close.

Chapter 2 traces the iconography of rainbows from early Christian art through the Renaissance and its symbolic vestiges in Elizabethan England. For a millennium, bows were painted with little regard for naturalistic accuracy. Their color sequence tended to be almost random and they were not always set in landscapes. Their job was often to serve as seat, footstool, or mandorla for Christ. Then, beginning perhaps with Giotto, more attention was paid to nature. Giotto, according to the authors, is probably the first painter to render the bow "not just as discrete stripes, but as imperceptibly merging regions of color." Dur- ing the Renaissance, rainbows were gradually restored to natural although often meteorologically impossible settings. But the rainbow remained a symbol of royal power in the painted hand of Queen Elizabeth.

Modern science rears its head in chapter 3, forcing landscape painters to embrace it or rebel against it as stifling. The authors choose to focus on a few rainbow paintings to indicate the scientific knowledge and attitudes of artists, and hence of the times. Angela Kaufmann's "Painting" is diagnosed as a barometer of how Newton's theories of light and color fared among artists. Here, as in other places, Lee and Fraser make tantalizing suggestions but reach no firm conclusions. The chapter examines several other puzzles. For example, why did the British landscape painter John Constable paint an impossible rainbow in his "Salisbury Cathedral from the Meadows" when he knew as much as any artist of the time about the rainbow's properties? The chapter concludes with a diagnosis of two rainbow paintings by the American artist Frederic Church, who envisioned nature as sublime and, with few exceptions, painted rainbows accurately and with an astounding sense of realism. Considering the thorough analysis, I was surprised that the authors did not point out that the distance between the two bows in Church's Rainy Season in the Tropics is only half what it should be but is correct in Church's study for the work.

Chapters 4 and 5 review rainbow theories from Aristotle through the Middle Ages, revealing them as a mix of fact and fancy with some astute observations and insights. Most interesting is the fact that around 1300 AD, Qutb Al-Din in Shiraz, Persia, and Theodoric in Freiberg, Germany, independently demonstrated that the rainbow is caused by light that is refracted twice and reflected once or twice inside a spherical raindrop. But these works were largely ignored for centuries. The historical review treads ground largely covered by Carl Boyer in The Rainbow: From Myth to Mathematics, but here it sets the stage for showing that many artists painted rainbows as a mix of fact and fancy replete with optical errors. One common error, resulting from assuming the rainbow is a solid object, is to paint it obliquely or wider in the foreground, even though the rainbow has a constant angular width. These errors are described with a mix of sympathy and humor that makes for most enjoyable and informative reading. 


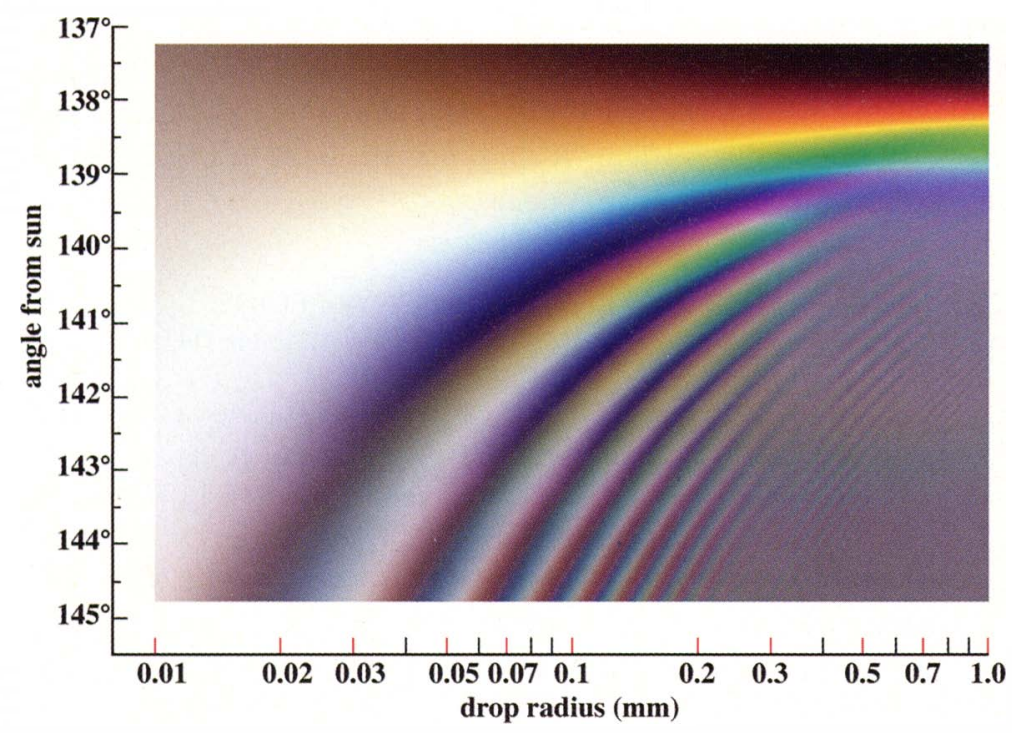

An interference theory's map of primary rainbow colors versus drop size (Airy theory). The colors have been smoothed (blurred) by the $0.5^{\circ}$ angular width of the sun.

Chapter 6 covers the triumphs of Descartes and Newton in explaining the main features of the rainbow. Descartes took the giant step of calculating how rays of light are deflected as they pass through a sphere, and Newton's theory of color explains the arrangement of colors in the bow. These theories did not win immediate or universal acceptance. Newton's theory even inspired a backlash, in part because it could not explain variations of color in rainbows or supernumerary rainbows and also because confusion persisted about the difference between combining different colors of light (additive) and different colors of pigment (subtractive).

Chapter 7 builds up to modern color theory and shows how painters from Rubens to Seurat sought guidance from scientists in applying color theory most effectively. The authors even discuss metamers-colors with different spectra that appear identical to the human eye. A critical analysis is made disputing Seurat's claims that pointillism is the way to maximize the brightness of paintings. Rainbow photographs are then analyzed and shown to be unexpectedly far from spectrally pure.

Chapter 8 points out the inadequacy of geometric optics to explain variations of color from one bow to another, and then introduces the wave theory of rainbows. Starting with Thomas Young's discovery that light consists of waves, and that supernumerary bows are due to interference, the authors go on to use Airy theory to map the rainbow's colors, width, and bright- ness as a function of drop size. The largest spherical drops produce the most vivid and spectral bows but no supernumeraries. As drop size decreases, supernumerary rainbows appear, broaden, and are finally replaced by a broad, white fogbow or cloudbow. The chapter concludes with an analysis of the almost colorless rainbows of the British sky painter, J. M. W. Turner. The authors point out that Turner studied rainbows but may have chosen to paint cloudbows - and, I might add, his fascination with mist and fog makes this conjecture more likely.

Chapter 9 focuses on some of the authors' recent findings and on rainbow features that are seldom seen, photographed, or painted. For example, they present simple geometric arguments that explain why the supernumerary bows are brightest near the top and why the secondary bow almost never has supernumeraries. Reflection rainbows are discussed although sadly without one of the spectacular photographs taken of this unusual phenomenon. The authors request a photo of a tertiary rainbow ("Readers, consider yourself challenged!"), which has been observed.

The book concludes in an almost anticlimactic manner with a potpourri of uses and abuses to which the rainbow has been subjected. Perhaps the most fitting of these monstrosities is the painting of discarded rainbows in a garbage can. Inserted here instead of in Chapter 9 where it belongs is an account of Mie theory and its use in describing rainbows.

The Rainbow Bridge traverses an immense ground with style, grace, wit, and insight. It will provide atmospheric scientists with an authoritative account of the scientific and cultural roots of their field. And perhaps most important, it will make all of us better observers. Atmospheric scientists who may never have thought of themselves as "cultured" may find themselves with an ability to diagnose paintings with unexpected discrimination and knowledge.

\section{- Stanley Gedzelman}

Stanley David Gedzelman is professor of earth and atmospheric sciences at the City College of New York, New York, NY. His e-mail address is stan@scisun.sci.ccny.cuny.edu. He has published in atmospheric optics and meteorological aspects of art. 
The following is a categorized list of all books that were announced and/or reviewed in the Bulletin from May 2001 to April 2002. The Bulletin issue in which a book was originally announced as a new publication and/or given a full book review appears after each title in this section. "R" indicates the issue in which the book was reviewed; "NP" indicates the issue in which the book was announced.

\section{AIR QUALITY/POLLUTION} AIR POLLUTION VIII

J. W. S. Longhurst, C. A. Brebbia, and H. Power, Eds., 2000, 786 pp., $\$ 385.00$, hardbound, Computational Mechanics, Inc., ISBN 1-85312822-8 (NP-5/0I)

AIR QUALITY MANAGEMENT J. W. S. Longhurst, D. M. Elsom, and H. Power, Eds., 2000, 312 pp., $\$ 149.00$, hardbound, WIT Press, ISBN I-853I2-528-8 (NP-12/0I)

\section{ATMOSPHERIC CHEMISTRY} AIR-SEA EXCHANGE: PHYSICS, CHEMISTRY AND DYNAMICS G. L. Geernaert, Ed., 1999, 578 pp., $\$ 240.00$, hardbound, Kluwer Academic, ISBN 0-7923-5937-2 (R-5/0I)

ATMOSPHERIC METHANE: ITS

ROLE IN THE GLOBAL

ENVIRONMENT

M. A. K. Khalil, Ed., 2000, 351 pp., $\$ 195.00$,

hardbound, Springer-Verlag, ISBN 3-540-65099-7 (R-2/02)

\section{GLOBAL BIOGEOCHEMICAL \\ CYCLES IN THE CLIMATE SYSTEM}

Ernst-Detlef Schulze et al., Eds., 200I, 350 pp., $\$ 89.95$, hardbound, Academic Press, ISBN 0-12631260-5 (R-3/02; NP-1/02)

INTRODUCTION TO ATMOSPHERIC CHEMISTRY Peter V. Hobbs. 2000. 262 pp. $\$ 24.95$. Paperbound. Cambridge University Press. ISBN 0-52I-77800-X (R-8/0I; NP-5/0I)

THE MECHANISMS OF ATMOSPHERIC OXIDATION OF THE ALKENES

J. G. Calvert et al., 2000, 560 pp., $\$ 105.00$, hardbound, Oxford University Press, ISBN 0-195I3I77-0 (R-5/0I)

OZONE AND CLIMATE CHANGE: A BEGINNER'S GUIDE S. J. Reid, 2000, 217 pp., $\$ 23.00$, paperbound, Gordon and Breach Science Publishers, ISBN 90 . 5679-233-3 (NP-6/0I)

\section{ATMOSPHERIC PHYSICS} THE ATMOSPHERIC FILTER. VOL. I: SOURCES, VOL. II: EFFECTS W. Michael Farmer, 200I, Vol. I: 273 pp.; Vol. 2: 336 pp., \$150.00, hardbound, JCD Publishing, ISBN 0-9640000-8-3 (R-3/02; NP-10/0I)

CLOUDS IN A GLASS OF BEER: SIMPLE EXPERIMENTS IN ATMOSPHERIC PHYSICS Craig F. Bohren, 200I, 195 pp., \$11.95, paperbound, Dover Publications, ISBN 0-48641738-7 (NP-10/0I)

THE ENERGY OF NATURE

E. C. Pielou, 200I, 256 pp., \$25.00, hardbound, The University of Chicago Press, ISBN 0-22666806-I (NP-8/0I)

FLOW INSTABILITY

D. N. Riahi, 2000, 244 pp., $\$ 126.00$, hardbound, WIT Press, ISBN I-85312-70I-9 (R-I/02; NP-9/0I)

\section{AN INTRODUCTION TO} ATMOSPHERIC PHYSICS David G. Andrews, 2000, 229 pp., $\$ 28.95$, paperbound, Cambridge University Press, ISBN 0-52I-62958-6 (NP-5/0I) IONOSPHERES: PHYSICS, PLASMA PHYSICS, AND CHEMISTRY Robert W. Schunk and Andrew E. Nagy. 2000. 554 pp. $\$ 100.00$. Hardbound. Cambridge University Press. ISBN 0-521-63237-4 (R-10/0I; NP-9/0I)

THE LIGHTNING DISCHARGE

M. A. Uman, 200I, 377 pp., \$17.95, paperbound, Dover Publications, ISBN 0-4864|463-9 (R-9/0I)

PHYSICAL PRINCIPLES OF REMOTE SENSING (SECOND EDITION)

W. G. Rees, 200I, 343 pp., $\$ 39.95$, paperbound, Cambridge University Press, ISBN 0-521-66948-0 (NP-3/02)

RADIATIVE TRANSFER IN THE ATMOSPHERE AND OCEAN Gary E. Thomas and Knut Stamnes, 1999, 517 pp., \$49.95, hardbound, Cambridge University Press, ISBN 0-52I-40|24-0 (R-5/0I)
THE RAINBOW BRIDGE: RAINBOWS IN ART, MYTH, AND SCIENCE

Raymond L. Lee Jr. and Alistair B. Fraser, 200I, 393 pp., \$65.00, hardbound, The Pennsylvania University Press, ISBN 0-271-129778 (NP-I2/0I)

SCATTERING OF WAVES FROM LARGE SPHERES.

W. T. Grandy Jr., 2000, 370 pp., $\$ 95.00$, hardbound, Cambridge University Press, ISBN 0-521-66126-9 (NP-7/0I)

SMALL SCALE PROCESSES IN GEOPHYSICAL FLUID FLOWS Lakshmi H. Kantha and Carol Anne Clayson, 2000, 1024 pp., \$115.00, hardbound, Academic Press, ISBN 0-12-434070-9 (R-5/0I)

\section{CLIMATE}

ATMOSPHERIC METHANE: ITS

ROLE IN THE GLOBAL

\section{ENVIRONMENT}

M. A. K. Khalil, Ed., 2000, 351 pp., $\$ 195.00$, hardbound, Springer-Verlag, ISBN 3-540-65099-7 (R-2/02)

GLOBAL BIOGEOCHEMICAL CYCLES IN THE CLIMATE SYSTEM

Ernst-Detlef Schulze et al., Eds., 200I, 350 pp., $\$ 89.95$, hardbound, Academic Press, ISBN 0-12-

631260-5 (R-3/02; NP-1/02)

SNOW ECOLOGY: AN

INTERDISCIPLINARY

EXAMINATION OF SNOW-

COVERED ECOSYSTEMS

H. G. Jones et al., Eds., 200I, 378 pp., $\$ 80.00$, hardbound, Cambridge University Press, ISBN

0-521-58483-3 (NP-2/02)

\section{SYNOPTIC AND DYNAMIC} CLIMATOLOGY

Roger G. Barry and Andrew M. Carleton, 200I, 620 pp., $\$ 60.00$, paperbound, Routledge, ISBN 0-4I5-03II6-8 (NP-4/02)

THE WEST ANTARCTIC ICE SHEET: BEHAVIOR AND ENVIRONMENT 
Richard B. Alley and Robert A. Bindschadle, Eds., 2000, 294 pp., \$65.00, hardbound, American Geophysical Union, ISBN 0-87590-957-4 (NP-5/0I)

\section{CLIMATE CHANGE/ VARIABILITY}

CLIMATE CHANGE: A MULTIDISCIPLINARY APPROACH W. J. Burroughs, 200I, 298 pp., $\$ 29.95$, paperbound, Cambridge University Press, ISBN 0-521-5677I-8 (NP-10/0I)

CLIMATE CHANGE IMPACTS ON THE UNITED STATES: THE POTENTIAL CONSEQUENCES OF CLIMATE VARIABILITY AND CHANGE

National Assessment Synthesis Team, 2000, 612 pp., \$39.95, paperbound, Cambridge University Press, ISBN 0-521-00075-0 (NP-9/0I)

CLIMATE CHANGE 200I: IMPACTS, ADAPTATION, AND VULNERABILITY

James J. McCarthy et al., Eds., 200I, 1032 pp., $\$ 49.95$, paperbound, Cambridge University Press, ISBN 0-52I-01500-6 (NP-I/02)

CLIMATE CHANGE 200I: MITIGATION

Bert Metz et al., Eds., 2001, 752 pp., $\$ 49.95$, paperbound, Cambridge University Press, ISBN 0-521-01502-2 (NP-I/02)

CLIMATE VARIABILITY IN SIXTEENTH CENTURY EUROPE AND ITS SOCIAL DIMENSION C. Pfister, R. Brázdil, and R. Glaser, Eds., 1999, 351 pp., $\$ 150.00$, hardbound, Kluwer Academic, ISBN 0-7923-5934-8 (NP-5/0I)

THE COMING STORM: EXTREME WEATHER AND OUR

TERRIFYING FUTURE

Bob Reiss, 200I, 323 pp., \$24.95, hardbound, Hyperion, ISBN 0-78-68-6665-9 (NP-I/02)

EL NIÑO AND THE SOUTHERN OSCILLATION: MULTISCALE VARIABILITY AND GLOBAL AND REGIONAL IMPACTS

H. F. Diaz and V. Markgraf, Eds. 2000. 496 pp. $\$ 90.00$. Hardbound. Cambridge University Press. ISBN 0-52I-62I38-0 (R-9/0I; NP-5/0I)

\section{GEOSPHERE-BIOSPHERE} INTERACTIONS AND CLIMATE Lennart 0. Bengtson and Claus U. Hammer, Eds., 2001, 302 pp., \$74.95, hardbound, Cambridge University Press, ISBN 0-52I-78238-4 (NP-4/02)
GLACIERS AND

ENVIRONMENTAL CHANGE

A. Nesje and S. 0. Dahl, 2000, 203 pp., $\$ 29.95$, hardbound, Oxford University Press, ISBN 0-34070634-I (R-9/0I)

GLOBAL WARMING: THE HARD SCIENCE

L. D. Danny Harvey, 2000, 336 pp., $\$ 18.99$, paperbound, Prentice Hall, ISBN 0-582-38I67-3 (NP-7/0I)

GLOBAL WARMING: THE SCIENCE OF CLIMATE CHANGE F. Drake, 2000, 273 pp., \$72.00, hardbound, copublished by Arnold Publications and Oxford University Press, ISBN 0-340-6530I 9 (paperbound, \$24.95, ISBN 0-340-65302) (R-9/0I)

HISTORY AND CLIMATE: MEMORIES OF THE FUTURE? P. D. Jones et al., Eds., 2001, 295 pp., $\$ 70.00$, hardbound, Kluwer Academic/Plenum Publishers, ISBN 0-306-46589-2 (NP-3/02)

THE OCEANS AND RAPID CLIMATE CHANGE: PAST, PRESENT AND FUTURE

Dan Seidov, Bernd J. Haupt, and Mark Maslin, Eds., 2001, 293 pp., $\$ 60.00$, hardbound, American Geophysical Union, ISBN 0-87590-985-X (NP-3/02) OZONE AND CLIMATE

CHANGE: A BEGINNER'S GUIDE S. J. Reid, 2000, 217 pp., $\$ 23.00$, paperbound, Gordon and Breach Science Publishers, ISBN 90-5679-233-3 (NP-6/0I)

THE TWO-MILE TIME MACHINE: ICE CORES, ABRUPT CLIMATE CHANGE, AND OUR FUTURE Richard B. Alley, 2000, 229 pp., \$24.95, hardbound, Princeton University Press, ISBN 0-691-00493-5 (R-2/02)

\section{DATA ANALYSIS/OBSERVING SYSTEMS}

DATA ANALYSIS METHODS IN

PHYSICAL OCEANOGRAPHY (SECOND EDITION)

W. J. Emery and R. E. Thomson, 2001, 638 pp., $\$ 69.00$, paperbound, Elsevier, ISBN 0-444-507574 (NP-II/OI)

EXPERIMENTAL ACOUSTIC INVERSION METHODS FOR EXPLORATION OF THE

SHALLOW WATER

ENVIRONMENT

A. Caiti et al., Eds., 2000, 308 pp., $\$ 127.00$, hardbound, Kluwer Academic, ISBN 0-7923-6305-I) (NP-5/0I)
METEOROLOGICAL MEASUREMENT SYSTEMS

Fred V. Brock and Scott J. Richardson. 200I. 304 pp. $\$ 65.00$. Hardbound. Oxford University Press. ISBN 0-19-5I345I-6 (R-I0/0I; NP-9/0I)

PHYSICAL PRINCIPLES OF REMOTE SENSING (SECOND EDITION)

W. G. Rees, 200I, 343 pp., $\$ 39.95$, paperbound, Cambridge University Press, ISBN 0-52I-66948-0 (NP-3/02)

REMOTE SENSING AND HYDROLOGY 2000

Manfred Owe et al., Eds., 200I, 610 pp., $£ 80.00$, IAHS Press, ISBN I-901502-46-5 (NP-2/02)

SATELLITE ALTIMETRY AND EARTH SCIENCES: A

HANDBOOK OF TECHNIQUES AND APPLICATIONS

Lee-Leung Fu and Anny Cazenave, Eds., 200I, 463 pp., \$104.95, hardbound, Academic Press, ISBN 0-12-269545-3 (NP-II/OI)

SATELLITES, OCEANOGRAPHY, AND SOCIETY

David Halpern, Ed., 2000, 376 pp., \$35.00, hardbound, Elsevier, ISBN 0-444-5050I-6 (R-5/0I)

\section{EL NIÑO/SOUTHERN OSCILLATION}

CURRENTS OF CHANGE: IMPACTS OF EL NIÑO AND LA NIÑA ON CLIMATE AND SOCIETY

M. H. Glantz, 200I, 252 pp., $\$ 24.95$, paperbound, Cambridge University Press, ISBN 0-521-78672-X (NP-8/0I)

EL NIÑO AND THE SOUTHERN OSCILLATION: MULTISCALE VARIABILITY AND GLOBAL AND REGIONAL IMPACTS

H. F. Diaz and V. Markgraf, Eds. 2000. 496 pp. $\$ 90.00$. Hardbound. Cambridge University Press. ISBN 0-52I-62I38-0 (R-9/0I; NP-5/0I)

EL NIÑO, 1997-1998: THE CLIMATE EVENT OF THE CENTURY

Stanley A. Changnon, Ed., 2000, 215 pp., $\$ 29.95$, paperbound, Oxford University Press, ISBN 0-19-

513552-0 (NP-5/0I)

NONLINEAR PHYSICAL OCEANOGRAPHY: A DYNAMICAL SYSTEMS APPROACH TO THE LARGE SCALE OCEAN CIRCULATION AND EL NIÑO 
Henk A. Dijkstra, 2000, 458 pp., $\$ 145.00$, hardbound, Kluwer Academic Publishers, ISBN 0-7923-6522-4 (R-I/02)

\section{ENVIRONMENT AND ECOLOGY} AIR QUALITY MANAGEMENT J. W. S. Longhurst, D. M. Elsom, and H. Power, Eds., 2000, 312 pp., $\$ 149.00$, hardbound, WIT Press, ISBN |-853I2-528-8 (NP-12/0I)

\section{APPLICATIONS OF SEASONAL} CLIMATE FORECASTING IN AGRICULTURAL AND NATURAL ECOSYSTEMS: THE AUSTRALIAN EXPERIENCE

G. L. Hammer, N. Nicholls, C. Mitchell, Eds. 2000. 469 pp. $\$ 200.00$. Hardbound. Kluwer Academic Publishers. ISBN 0-7923-6270-5 (R-10/ OI; NP-9/0I)

ATMOSPHERIC METHANE: ITS ROLE IN THE GLOBAL ENVIRONMENT

M. A. K. Khalil, Ed., 2000, 351 pp., $\$ 195.00$, hardbound, Springer-Verlag, ISBN 3-540-65099-7 (R-2/02)

CLIMATE CHANGE 200I: IMPACTS, ADAPTATION, AND VULNERABILITY

James J. McCarthy et al., Eds., 200I, 1032 pp., $\$ 49.95$, paperbound, Cambridge University Press, ISBN 0-521-01500-6 (NP-I/02)

ENVIRONMENTAL HAZARDS: ASSESSING RISK AND REDUCING DISASTER (THIRD EDITION)

Keith Smith. 2001. 392 pp. \$32.99. Paperbound. (\$100.00. Hardbound) Routledge. ISBN 0-415-

22464-0 (R-10/0I; NP-5/0I)

ENVIRONMENTAL HEALTH RISK C. A. Brebbia and D. Fajzieva, Eds., 200I, 328 pp., \$199.00, hardbound, WIT Press, ISBN |-853|2-875-9 (NP-12/0|)

GLACIERS AND

ENVIRONMENTAL CHANGE

A. Nesje and S. 0. Dahl, 2000, 203 pp., $\$ 29.95$, hardbound, Oxford University Press, ISBN 0-34070634-I (R-9/0I)

GLOBAL BIOGEOCHEMICAL CYCLES IN THE CLIMATE SYSTEM

Ernst-Detlef Schulze et al., Eds., 200I, 350 pp., $\$ 89.95$, hardbound, Academic Press, ISBN 0-12631260-5 (R-3/02; NP-I/02)
HYDRO-ECOLOGY: LINKING HYDROLOGY AND AQUATIC ECOLOGY

M. C. Acreman, Ed., 200I, 162 pp., E33.00, IAHS

Press, ISBN 1-901502-41-4 (NP-2/02)

IMPACT OF HUMAN ACTIVITY

ON GROUNDWATER DYNAMICS

Hans Gehrels et al., Eds., 200I, 369 pp., £59.50,

IAHS Press, ISBN I-901502-56-2 (NP-2/02)

\section{LAKE CHAMPLAIN IN \\ TRANSITION: FROM RESEARCH \\ TOWARD RESTORATION}

Thomas 0. Manley and Patricia L. Manley, Eds., 1999, 451 pp., \$55.00, hardbound, American Geophysical Union, ESBN 0-87590-350-9 (NP-12/0I)

REGIONAL MANAGEMENT OF WATER RESOURCES

A. H. Schumann et al., Eds., 200I, 288 pp., Ł47.75, IAHS Press, ISBN I-901502-51-I (NP-2/02)

SNOW ECOLOGY: AN

INTERDISCIPLINARY

EXAMINATION OF SNOW-

COVERED ECOSYSTEMS

H. G. Jones et al., Eds., 200I, 378 pp., $\$ 80.00$,

hardbound, Cambridge University Press, ISBN

0-521-58483-3 (NP-2/02)

SOIL-VEGETATION-

ATMOSPHERE TRANSFER

SCHEMES AND LARGE-SCALE HYDROLOGICAL MODELS

A. J. Dolman et al., Eds., 200I, 372 pp., 659.50 , IAHS Press, ISBN I-901502-61-9 (NP-2/02)

WATER POLLUTION VI:

MODELLING, MEASURING AND

PREDICTION

C. A. Brebbia, Ed., 2001, 568 pp., $\$ 299.00$,

hardbound, WIT Press, ISBN I-853I2-878-3 (NP-2/ 02)

\section{WATER RESOURCE \\ MANAGEMENT}

C. A. Brebbia et al., Eds., 200I, 412 pp., $\$ 210.00$, hardbound, WIT Press, ISBN I-85312880-5 (NP-I/02)

\section{FORECASTING}

APPLICATIONS OF SEASONAL CLIMATE FORECASTING IN AGRICULTURAL AND NATURAL ECOSYSTEMS: THE AUSTRALIAN EXPERIENCE

G. L. Hammer, N. Nicholls, C. Mitchell, Eds. 2000. 469 pp. $\$ 200.00$. Hardbound. Kluwer Academic Publishers. ISBN 0-7923-6270-5 (R-10/ OI; NP-9/0I)
HURRICANE WATCH:

FORECASTING THE DEADLIEST

STORMS ON EARTH

Dr. Bob Sheets and Jack Williams, 200I, 33I

Pp., $\$ 15.00$, paperbound, Vintage Books, ISBN

0-375-70390-X (R-4/02; NP-12/0I)

INSTANT WEATHER

FORECASTING (SECOND

EDITION)

Alan Watts, 2001, 64 pp., \$7.95, paperbound, Sheridan House, ISBN I-57409I-36-0 (NP-4/02)

THE INTERNATIONAL

ANTARCTIC WEATHER

FORECASTING HANDBOOK

John Turner and Steve Pendlebury, 691 pp.

[Version 1.3 is available for download from the British Antarctic Survey FTP site (details at www.nerc-bas.ac.uk/public/icd/jtu/ftpinst.html) or through the "Operations/Meteorology" links at the Council of Managers of National Antarctic Programs site at www.comnap.aq] (NP-2/02)

SCANNING THE SKIES: A

HISTORY OF TORNADO

FORECASTING

Marlene Bradford. 2001.220 pp. $\$ 24.95$.

Hardbound. University of Oklahoma Press. ISBN

0-806I-3302-3 (R-I2/0I; NP-8/0I)

\section{GENERAL INTEREST}

AMERICANS AND THEIR WEATHER

W. B. Meyer, 2000, 278 pp., \$35.00, hardbound, Oxford University Press, ISBN 0-19-513182-7

(NP-8/0I)

\section{CLIMATE CHANGE: A} MULTIDISCIPLINARY APPROACH

W. J. Burroughs, 200I, 298 pp., $\$ 29.95$, paperbound, Cambridge University Press, ISBN 0-521-56771-8 (NP-10/0I)

CLOUDS IN A GLASS OF BEER: SIMPLE EXPERIMENTS IN ATMOSPHERIC PHYSICS Craig F. Bohren, 200I, 195 pp., \$1I.95, paperbound, Dover Publications, ISBN 0-4864I738-7 (NP-10/0I)

THE COLDEST MARCH: SCOTT'S FATAL ANTARCTIC EXPEDITION Susan Solomon, 200I, 383 pp., $\$ 29.95$, hardbound, Yale University Press, ISBN 0-30008967-8 (R-4/02; NP-I2/0I)

\section{THE COLORADO WEATHER} BOOK

Mike Nelson and the 9NEWS Weather Team, 1999, 136 pp., \$24.95, paperbound, Westcliffe Publishers, ISBN I-56579-342-0 (NP-6/0I) 
THE COMING STORM: EXTREME WEATHER AND OUR TERRIFYING FUTURE

Bob Reiss, 200I, 323 pp., \$24.95, hardbound, Hyperion, ISBN 0-78-68-6665-9 (NP-1/02)

A DICTIONARY OF WEATHER

Storm Dunlop, 200I, 296 pp., \$13.95,

paperbound, Oxford University Press, ISBN 0-19-

280063-9 (NP-3/02)

DUE TO THE WEATHER: WAYS

THE ELEMENTS AFFECT OUR

LIVES

Abraham Resnick, 2000, 240 pp., $\$ 45.00$,

hardbound, Greenwood Press, ISBN 0-3|3-31344-

$X(\mathrm{R}-8 / 0 \mathrm{I})$

THE ENERGY OF NATURE

E. C. Pielou, 200I, 256 pp., $\$ 25.00$, hardbound,

The University of Chicago Press, ISBN 0-226-

66806-I (NP-8/01)

THE FACTS ON FILE

DICTIONARY OF WEATHER

AND CLIMATE

Jacqueline Smith, 200I, 256 pp., $\$ 44.00$, hardbound, Facts on File, Inc., ISBN $0-8160$ 4532-I (NP-3/02)

GLOBAL WARMING:

THE HARD SCIENCE

L. D. Danny Harvey, 2000, 336 pp., \$18.99,

paperbound, Prentice Hall, ISBN 0-582-38I67-3

(NP-7/0I)

HOW'S THE WEATHER?: FIND YOUR OUTDOORS COMFORT PARADISE IN THE U.S.

James L. Kennedy, 2002, 272 pp., $\$ 29.95$, paperbound, ASK Analytic Services, Inc., ISBN 0-9703|23-0-X (NP-4/02)

HURRICANE WATCH: FORECASTING THE DEADLIEST STORMS ON EARTH

Dr. Bob Sheets and Jack Williams, 200I, 33I

pp., \$15.00, paperbound, Vintage Books, ISBN

0-375-70390-X (R-4/02; NP-12/0I)

THE INVENTION OF CLOUDS:

HOW AN AMATEUR

METEOROLOGIST FORGED THE

LANGUAGE OF THE SKIES

Richard Hamblyn, 2001, 403 pp., $\$ 27.00$,

hardbound, Farrar, Straus and Giroux, ISBN

0-374-17715-5 (NP-1/02)

INSIDE THE HURRICANE: FACE

TO FACE WITH NATURE'S

DEADLIEST STORMS

Pete Davies, 2000, 264 pp., $\$ 25.00$, hardbound, Henry Holt and Company, ISBN 0-8050-6574-I (R-7/0I)
INSTANT WEATHER

FORECASTING

(SECOND EDITION)

Alan Watts, 2001, 64 pp., \$7.95, paperbound,

Sheridan House, ISBN I-57409I-36-0 (NP-4/02)

NATURE'S FURY: EYEWITNESS

REPORTS OF NATURAL

DISASTERS

Carole G. Vogel, 2000, 127 pp., \$16.95,

hardbound, Scholastic, Inc., ISBN 0-590-1/502-2

(R-I/0I; NP-5/0I)

NOAH'S FLOOD: THE NEW

SCIENTIFIC DISCOVERIES ABOUT

THE EVENT THAT CHANGED

HISTORY

W. Ryan and W. Pitman, 2000, 319 pp., $\$ 14.00$, paperbound, Simon and Schuster, ISBN

0-68485920-3 (NP-8/0I)

THE RAINBOW BRIDGE:

RAINBOWS IN ART, MYTH,

AND SCIENCE

Raymond L. Lee Jr. and Alistair B. Fraser,

200I, 393 pp., \$65.00, hardbound, The

Pennsylvania University Press, ISBN 0-27I-

12977-8 (NP-12/0I)

THE TWO-MILE TIME MACHINE: ICE CORES, ABRUPT CLIMATE CHANGE, AND OUR FUTURE Richard B. Alley, 2000, 229 pp., \$24.95, hardbound, Princeton University Press, ISBN 0-691-00493-5 (R-2/02)

\section{WEATHER FOR DUMMIES}

John D. Cox. 2000. 358 pp. \$19.99. Paperbound. IDG Books Worldwide. ISBN 0-7645-5243-0

(R-II/0I; NP-6/0I)

WEATHER HISTORY AND CLIMATE GUIDE TO THE LOWER HUDSON VALLEY

J. S. Thaler, 2000, 213 pp., $\$ 25.00$, paperbound, George Candreva Environmental Center, Inc., ISBN 0-9705688-0-0 (NP-7/0I)

\section{HISTORY}

\section{AMERICANS AND THEIR WEATHER}

W. B. Meyer, 2000, 278 pp., $\$ 35.00$, hardbound, Oxford University Press, ISBN 0-19-513182-7 (NP-8/0I)

CLIMATE VARIABILITY IN SIXTEENTH CENTURY EUROPE AND ITS SOCIAL DIMENSION

C. Pfister, R. Brázdil, and R. Glaser, Eds., 1999, 351 pp., $\$ 150.00$, hardbound, Kluwer Academic, ISBN 0-7923-5934-8 (NP-5/0I)
THE COLDEST MARCH: SCOTT'S FATAL ANTARCTIC EXPEDITION

Susan Solomon, 200I, 383 pp., $\$ 29.95$, hardbound, Yale University Press, ISBN 0-30008967-8 (R-4/02; NP-I2/0I)

EVEN THE BIRDS WERE WALKING: THE STORY OF WARTIME METEOROLOGICAL RECONNAISSANCE

J. A. Kington and Peter G. Rackliff. 2000. 192 pp. \$39.99. Hardbound. Tempus Publishing Limited. ISBN 0-7524-2016-X (R-II/0I; NP-10/0I)

HISTORY AND CLIMATE: MEMORIES OF THE FUTURE? P. D. Jones et al., Eds., 200I, 295 pp., $\$ 70.00$, hardbound, Kluwer Academic/Plenum Publishers, ISBN 0-306-46589-2 (NP-3/02)

THE INVENTION OF CLOUDS: HOW AN AMATEUR METEOROLOGIST FORGED THE LANGUAGE OF THE SKIES Richard Hamblyn, 200I, 403 pp., \$27.00, hardbound, Farrar, Straus and Giroux, ISBN 0-374-177/5-5 (NP-I/02)

NOAH'S FLOOD: THE NEW SCIENTIFIC DISCOVERIES ABOUT THE EVENT THAT CHANGED HISTORY

W. Ryan and W. Pitman, 2000, 319 pp., $\$ 14.00$, paperbound, Simon and Schuster, ISBN 0-68485920-3 (NP-8/0I)

THE RAINBOW BRIDGE: RAINBOWS IN ART, MYTH, AND SCIENCE

Raymond L. Lee Jr. and Alistair B. Fraser, 200I, 393 pp., \$65.00, hardbound, The Pennsylvania University Press, ISBN 0-27I12977-8 (NP-12/0I)

SCANNING THE SKIES: A HISTORY OF TORNADO FORECASTING

Marlene Bradford. 2001.220 pp. $\$ 24.95$. Hardbound. University of Oklahoma Press. ISBN 0-806I-3302-3 (R-I2/0I; NP-8/0I)

WEATHER HISTORY AND CLIMATE GUIDE TO THE LOWER HUDSON VALLEY

J. S. Thaler, 2000, 213 pp., $\$ 25.00$, paperbound, George Candreva Environmental Center, Inc., ISBN 0-9705688-0-0 (NP-7/0I) 
HURRICANES

HURRICANE WATCH: FORECASTING THE DEADLIEST STORMS ON EARTH

Dr. Bob Sheets and Jack Williams, 200I, 33I Pp., $\$ 15.00$, paperbound, Vintage Books, ISBN 0-375-70390-X (R-4/02; NP-12/0I)

INSIDE THE HURRICANE: FACE TO FACE WITH NATURE'S DEADLIEST STORMS

Pete Davies, 2000, 264 pp., $\$ 25.00$, hardbound, Henry Holt and Company, ISBN 0-8050-6574-I (R-7/0I)

\section{HYDROLOGY}

DISTRIBUTED HYDROLOGIC MODELING USING GIS

Baxter E. Vieux, 200I, 293 pp., $\$ 89.00$,

hardbound, Kluwer Academic, ISBN 0-7923-7002-3 (NP-12/0I)

HYDRO-ECOLOGY: LINKING HYDROLOGY AND AQUATIC ECOLOGY

M. C. Acreman, Ed., 200I, 162 pp., E33.00, IAHS Press, ISBN 1-901502-41-4 (NP-2/02)

IMPACT OF HUMAN ACTIVITY ON GROUNDWATER DYNAMICS
Hans Gehrels et al., Eds., 200I, 369 pp., E59.50, IAHS Press, ISBN I-901502-56-2 (NP-2/02)

LAKE CHAMPLAIN IN TRANSITION: FROM RESEARCH TOWARD RESTORATION

Thomas 0. Manley and Patricia L. Manley, Eds., 1999, 451 pp., \$55.00, hardbound, American Geophysical Union, ISBN 0-87590-350-9 (NP-I2/0I)

LAND SURFACE HYDROLOGY, METEOROLOGY AND CLIMATE: OBSERVATIONS AND MODELING Venkataraman Lakshmi, John Albertson, and John Schaake, Eds., 200I, 246 pp., $\$ 55.00$, hardbound, American Geophysical Union, ISBN 0-87590-352-5 (NP-12/0I)

\section{PUBLISHERS ADDRESSES}

ACADEMIC PRESS, INC., Book Marketing Dept., 525 B Street, Suite 1900, San Diego, CA 921014495; Telephone: 619-231-0926; www.apnet.com

CAMBRIDGE UNIVERSITY PRESS, 40 West 20th St., New York, NY 10011-4221; Telephone: 212-924-3900; www.cup.org

DOVER PUBLICATIONS, 31 East 2nd Street, Mineola, NY 11501-3852; Telephone: 516-2947000; store.doverpublications.com

ELSEVIER SCIENCE, 655 Avenue of the Americas, New York, NY 10010-5107; Telephone: 212989-5800; www.elsevier.com

GREENWOOD, 88 Post Road West, P.O. Box 5007, Westport, CT 06881-5007; Telephone: 800-225-5800; www.greenwood.com

GREY HOUSE PUBLISHING, 185 Millerton Road, P.O. Box 860, Millerton, NY 12546; Telephone: 800-562-2139; www.greyhouse.com

HENRY HOLT AND COMPANY, 115 West 18th Street, New York, NY 10011; Telephone: 212886-9200; www.henryholt.com

IDG BOOKS WORLDWIDE, 909 Third Avenue, New York, NY 10022; Telephone: 800-762-2974; www.idgbooks.com

JCD PUBLISHING, 2932 Cove Trail, Winter Park, FL 32789-1159; Telephone: 406-629-5370; www.jcdpublishing.com

KLUWER ACADEMIC PUBLISHERS, 101 Philip Dr., Assinippi Park, Norwell, MA 02061; Telephone: 781-871-6600; www.wkap.nl

OXFORD UNIVERSITY PRESS, 198 Madison Ave., New York, NY 10016; Telephone: 212726-6000; www.oup-usa.org
PRINCETON UNIVERSITY PRESS, 41 William Street, Princeton, NJ 08540-5237; Telephone: 609-258-4900; pup.princeton.edu

ROUTLEDGE, Customer Service, 7625 Empire Drive, Florence, KY 41042; Telephone: 800-6347064; www.routledge-ny.com

SCHOLASTIC INC., 557 Broadway, New York, NY 10012; Telephone: 212-343-6100; www.scholastic.com

SPRINGER-VERLAG, 175 Fifth Avenue, New York, NY 10010; Telephone: 212-460-1500; www.springer-ny.com

TEMPUS PUBLISHING LTD., The Mill, Brimscombe Port, Stroud, Gloucestershire GL5 2QG, United Kingdom; Telephone: 01453 883300; www.tempus-publishing.com

UNIVERSITY OF OKLAHOMA PRESS, 1005 Asp Avenue, Norman, OK 73019-6051; Telephone: 800-627-7377; www.ou.edu/oupress

VINTAGE BOOKS, Random House, Inc., 1540 Broadway, New York, NY 10036; Telephone: 800-733-3000; www.randomhouse.com/vintage

WESTWIND WEATHER SERVICES, 14 Shrewsbury Road, Edgmond, Newport, Shropshire TF1O 8HT, United Kingdom; www.westwind.demon.co.uk/weather

WIT PRESS, Ashurst Lodge, Ashurst, Southampton SO40 7AA, United Kingdom; Telephone: 44 (0) 238029 3223; www.cmp.co.uk

YALE UNIVERSITY PRESS, P.O. Box 209040, New Haven CT 06520-9040; Telephone: 203432-0960; www.yale.edu/yup 
LAND USE AND WATERSHEDS: HUMAN INFLUENCE ON HYDROLOGY AND GEOMORPHOLOGY IN URBAN AND FOREST AREAS

Mark S. Wigmosta and Stephen J. Burges, Eds., 2001, 227 pp., \$55.00, hardbound, American Geophysical Union, ISBN 0-87590-35I-7 (NP-12/0I) REGIONAL MANAGEMENT OF WATER RESOURCES

A. H. Schumann et al., Eds., 2001,288 pp., 447.75, IAHS Press, ISBN I-901502-5I-I (NP-2/02)

REMOTE SENSING AND HYDROLOGY 2000

Manfred Owe et al., Eds., 2001, 610 pp., 880.00, IAHS Press, ISBN I-901502-46-5 (NP-2/02)

SOIL-VEGETATIONATMOSPHERE TRANSFER SCHEMES AND LARGE-SCALE HYDROLOGICAL MODELS

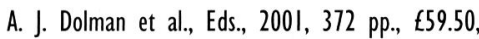
IAHS Press, ISBN I-901502-61-9 (NP-2/02)

STOCHASTIC METHODS FOR FLOW IN POROUS MEDIA: COPING WITH UNCERTAINTIES Dongziao Zhang, 2002, 350 pp., \$79.95, hardbound, Academic Press, ISBN 0-12-77962I-5 (NP-3/02)

WATER RESOURCE MANAGEMENT

C. A. Brebbia et al., Eds., 2001, 412 pp., $\$ 210.00$, hardbound, WIT Press, ISBN 1-85312880-5 (NP-1/02)

\section{LIGHTNING}

THE LIGHTNING DISCHARGE

M. A. Uman, 2001, 377 pp., $\$ 17.95$, paperbound, Dover Publications, ISBN 0-486-4I463-9 (R-9/0I)

\section{MICROMETEOROLOGY}

INTRODUCTION TO

MICROMETEOROLOGY

(SECOND EDITION)

S. Pal Arya, 2001,420 pp., $\$ 79.95$, hardbound, Academic Press, ISBN 0-12-059354-8 (NP-II/0I)

\section{MISCELLANEOUS}

THE COLORADO WEATHER BOOK

Mike Nelson and the 9NEWS Weather Team, 1999, 136 pp., \$24.95, paperbound, Westcliffe Publishers, ISBN 1-56579-342-0 (NP-6/0I)
CONTROLLING PILOT ERROR: WEATHER

Terry T. Lankford, 2001, 200 pp., $\$ 19.95$, paperbound, McGraw-Hill Professional Publishing, ISBN 0-07-137328-4 (NP-3/02)

MOUNTAIN METEOROLOGY: FUNDAMENTALS AND

APPLICATIONS

C. David Whiteman, 2000, 368 pp., $\$ 39.95$, hardbound, Oxford University Press, ISBN 0-1951327I-8 (R-5/0I)

WEATHER OF THE 90S: A DECADE OF WEATHER AND CLIMATE IN THE UK.

Peter B. Wright. 2000. 76 pp. $\mathrm{E} / 2.95$.

Paperbound. Westwind Weather Services. ISBN

0-95397/0-0-7(R-8/0I; NP-7/0I)

\section{MODELING}

COASTAL ENGINEERING V: COMPUTER MODELLING OF SEAS AND COASTAL REGIONS C. A. Brebbia, Ed., 2001, 344 pp., $\$ 194.00$, hardbound, WIT Press, ISBN 1-85312-879-I (NP-I2/0I)

DISTRIBUTED HYDROLOGIC MODELING USING GIS

Baxter E. Vieux, 200I, 293 pp., $\$ 89.00$,

hardbound, Kluwer Academic, ISBN 0-7923-7002-3 (NP-12/0I)

GENERAL CIRCULATION MODEL DEVELOPMENT

David J. Randall, Ed., 2000, 416 pp., $\$ 99.95$, hardbound, Academic Press, ISBN 0-12-5780I0-9 (R-5/0I)

LAND USE AND WATERSHEDS: HUMAN INFLUENCE ON

HYDROLOGY AND

GEOMORPHOLOGY IN URBAN AND FOREST AREAS

Mark S. Wigmosta and Stephen J. Burges, Eds., 2001, 227 pp., \$55.00, hardbound, American Geophysical Union, ISBN 0-87590-35I-7 (NP-I2/0I)

SOIL-VEGETATION-

ATMOSPHERE TRANSFER

SCHEMES AND LARGE-SCALE

HYDROLOGICAL MODELS

A. J. Dolman et al., Eds., 200I, 372 pp., 659.50 , IAHS Press, ISBN I-901502-6I-9 (NP-2/02) STOCHASTIC METHODS FOR FLOW IN POROUS MEDIA: COPING WITH UNCERTAINTIES Dongziao Zhang, 2002, 350 pp., $\$ 79.95$, hardbound, Academic Press, ISBN 0-12-779621-5 (NP-3/02)
WATER POLLUTION VI: MODELLING, MEASURING AND PREDICTION

C. A. Brebbia, Ed., 2001,568 pp., $\$ 299.00$, hardbound, WIT Press, ISBN I-853।2-878-3 (NP-2/02)

\section{OCEAN-ATMOSPHERE INTERACTION}

AIR-SEA EXCHANGE: PHYSICS, CHEMISTRY AND DYNAMICS

G. L. Geernaert, Ed., 1999, 578 pp., $\$ 240.00$, hardbound, Kluwer Academic, ISBN 0-7923-5937-2 (R-5/0I)

AIR-SEA INTERACTION: LAWS AND MECHANISMS

G. T. Csanady, 200I, 239 pp., $\$ 34.95$, paperbound, Cambridge University Press, ISBN 0-52I-79680-6 (R-2/02; NP-II/OI)

WIND STRESS OVER

THE OCEAN

lan S. F. Jones and Yoshiaki Toba, 200I, 307 pp., $\$ 80.00$, hardbound, Cambridge University Press, ISBN 0-521-66243-5 (NP-4/02)

\section{OCEANOGRAPHY}

COASTAL ENGINEERING V: COMPUTER MODELLING OF SEAS AND COASTAL REGIONS C. A. Brebbia, Ed., 200I, 344 pp., $\$ 194.00$, hardbound, WIT Press, ISBN 1-85312-879-I (NP-12/0I)

\section{COASTAL OCEANOGRAPHY}

Tetsuo Yanagi, 2000, 162 pp., $\$ 80.00$, hardbound, Kluwer Academic Publishers, ISBN 0-7923-5895-3 (R-3/02)

DATA ANALYSIS METHODS IN PHYSICAL OCEANOGRAPHY (SECOND EDITION)

W. J. Emery and R. E. Thomson, 2001, 638 pp., $\$ 69.00$, paperbound, Elsevier, ISBN 0-444-507574 (NP-II/OI)

DESCRIPTIVE PHYSICAL OCEANOGRAPHY

M. P. M. Reddy, 200I, 440 pp., $\$ 85.00$, hardbound, A. A. Balkema Publishers, ISBN 90-54I0-706-5 (NP-I/02)

EXPERIMENTAL ACOUSTIC INVERSION METHODS FOR EXPLORATION OF THE SHALLOW WATER ENVIRONMENT

A. Caiti et al., Eds., 2000, 308 pp., $\$ 127.00$, hardbound, Kluwer Academic, ISBN 0-7923-6305I) (NP-5/0I) 
THE FRESHWATER BUDGET OF THE ARCTIC OCEAN

E. L. Lewis, Ed., 2000, 623 pp., $\$ 208.00$, hardbound, Kluwer Academic, ISBN 0-7923-6439-2 (NP-5/0I)

NONLINEAR PHYSICAL

OCEANOGRAPHY: A

DYNAMICAL SYSTEMS

APPROACH TO THE LARGE

SCALE OCEAN CIRCULATION

AND EL NIÑO

Henk A. Dijkstra, 2000, 458 pp., $\$ 145.00$,

hardbound, Kluwer Academic Publishers, ISBN

0-7923-6522-4 (R-I/02)

OCEAN CIRCULATION (SECOND EDITION)

Prepared by Angela Colling for the Open University Course Team, 200I, 242 pp., \$37.95, paperbound, Butterworth-Heinemann, ISBN 0-750-65278-0 (NP-4/02)

THE OCEANS AND RAPID CLIMATE CHANGE: PAST, PRESENT AND FUTURE

Dan Seidov, Bernd J. Haupt, and Mark Maslin, Eds., 2001, 293 pp., \$60.00, hardbound, American Geophysical Union, ISBN 0-87590-985-X (NP-3/02)

RADIATIVE TRANSFER IN THE ATMOSPHERE AND OCEAN

Gary E. Thomas and Knut Stamnes, 1999, 517 pp., \$49.95, hardbound, Cambridge University Press, ISBN 0-52I-40|24-0 (R-5/0I)

SATELLITES, OCEANOGRAPHY, AND SOCIETY

David Halpern, Ed., 2000, 376 pp., $\$ 35.00$, hardbound, Elsevier, ISBN 0-444-5050I-6 (R-5/0I)

TSUNAMI: THE UNDERRATED HAZARD

Edward Bryant, 200I, 320 pp., \$74.95hardbound, \$27.95-paperback, Cambridge University Press, ISBN 0-521-77244-3 (HB); $0-521-77599-X$ (PB) (R-3/02; NP-I/02)

WIND STRESS OVER THE OCEAN lan S. F. Jones and Yoshiaki Toba, 200I, 307 pp., \$80.00, hardbound, Cambridge University Press, ISBN 0-52I-66243-5 (NP-4/02)

\section{REFERENCE}

A DICTIONARY OF WEATHER

Storm Dunlop, 2001, 296 pp., \$13.95,

paperbound, Oxford University Press, ISBN 0-19280063-9 (NP-3/02)
THE FACTS ON FILE DICTIONARY OF WEATHER AND CLIMATE

Jacqueline Smith, 200I, 256 pp., $\$ 44.00$, hardbound, Facts on File, Inc., ISBN 0-81604532-I (NP-3/02)

HOW'S THE WEATHER?: FIND YOUR OUTDOORS COMFORT PARADISE IN THE U.S.

James L. Kennedy, 2002, 272 pp., \$29.95, paperbound, ASK Analytic Services, Inc., ISBN 0-9703I23-0-X (NP-4/02)

\section{OXFORD COMPANION}

TO THE EARTH

Paul L. Hancock and Brian J. Skinner, Eds., 2001, 1024 pp., $\$ 60.00$, hardbound, 0xford University Press, ISBN 0-19-854039-6 (NP-|l/OI)

WEATHER AMERICA: A THIRTY-YEAR SUMMARY OF STATISTICAL WEATHER DATA AND RANKINGS

(SECOND EDITION)

David Garoogian, 2000, 2013 pp., \$175.00, paperbound, Grey House Publishing, ISBN I-89|482-29-7 (R-7/0I)

WEATHER HISTORY AND CLIMATE GUIDE TO THE LOWER HUDSON VALLEY

J. S. Thaler, 2000, 213 pp., $\$ 25.00$, paperbound, George Candreva Environmental Center, Inc., ISBN 0-9705688-0-0 (NP-7/0I)

\section{SOCIETAL IMPACT}

AMERICANS AND THEIR WEATHER

W. B. Meyer, 2000, 278 pp., $\$ 35.00$, hardbound, Oxford University Press, ISBN 0-19-513182-7 (NP-8/0I)

APPLICATIONS OF SEASONAL CLIMATE FORECASTING IN AGRICULTURAL AND NATURAL ECOSYSTEMS: THE AUSTRALIAN EXPERIENCE

G. L. Hammer, N. Nicholls, C. Mitchell, Eds. 2000. 469 pp. $\$ 200.00$. Hardbound. Kluwer Academic Publishers. ISBN 0-7923-6270-5 (R-I0/ 0I; NP-9/0I)

CHANGING THE ATMOSPHERE: EXPERT KNOWLEDGE AND ENVIRONMENTAL

GOVERNANCE

Clark A. Miller and Paul N. Edwards, Eds., 200I, 385 pp., \$26.95, paperbound, MIT Press, ISBN 0-262-63219-5 (NP-3/02)
CLIMATE CHANGE: A MULTIDISCIPLINARY APPROACH

W. J. Burroughs, 200I, 298 pp., $\$ 29.95$, paperbound, Cambridge University Press, ISBN 0-521-56771-8 (NP-10/01)

CLIMATE CHANGE IMPACTS ON

THE UNITED STATES: THE POTENTIAL CONSEQUENCES OF CLIMATE VARIABILITY AND

\section{CHANGE}

National Assessment Synthesis Team, 2000, 612 Pp., \$39.95, paperbound, Cambridge University Press, ISBN 0-521-00075-0 (NP-9/0I)

CLIMATE CHANGE 200I: IMPACTS, ADAPTATION, AND VULNERABILITY

James J. McCarthy et al., Eds., 200I, 1032 pp., $\$ 49.95$, paperbound, Cambridge University Press, ISBN 0-52I-01500-6 (NP-I/02)

CLIMATE CHANGE 200I: MITIGATION

Bert Metz et al., Eds., 200I, 752 pp., $\$ 49.95$, paperbound, Cambridge University Press, ISBN

0-521-01502-2 (NP-1/02)

CLIMATE VARIABILITY IN SIXTEENTH CENTURY EUROPE AND ITS SOCIAL DIMENSION

C. Pfister, R. Brázdil, and R. Glaser, Eds., 1999, 351 pp., $\$ 150.00$, hardbound, Kluwer Academic, ISBN 0-7923-5934-8 (NP-5/0I)

THE COMING STORM: EXTREME WEATHER AND OUR

TERRIFYING FUTURE Bob Reiss, 200I, 323 pp., \$24.95, hardbound, Hyperion, ISBN 0-78-68-6665-9 (NP-I/02)

CURRENTS OF CHANGE: IMPACTS OF EL NIÑO AND LA NIÑA ON CLIMATE AND SOCIETY

M. H. Glantz, 200I, 252 pp., $\$ 24.95$, paperbound, Cambridge University Press, ISBN 0-521-78672-X (NP-8/0I)

DUE TO THE WEATHER: WAYS THE ELEMENTS AFFECT OUR LIVES

Abraham Resnick, 2000, 240 pp., $\$ 45.00$, hardbound, Greenwood Press, ISBN 0-313-31344-X (R-8/0I)

EL NIÑO, 1997-1998: THE CLIMATE EVENT OF THE CENTURY

Stanley A. Changnon, Ed., 2000, 215 pp., $\$ 29.95$, paperbound, Oxford University Press, ISBN 0-19513552-0 (NP-5/0I) 
ENVIRONMENTAL HAZARDS: ASSESSING RISK AND REDUCING DISASTER (THIRD EDITION)

Keith Smith, 200I, 392 pp., \$32.99, paperbound, (\$100.00, hardbound) Routledge, ISBN 0-41522464-0 (R-10/0I; NP-5/0I)

GLOBAL WARMING: THE HARD SCIENCE

L. D. Danny Harvey, 2000, 336 pp., \$18.99, paperbound, Prentice Hall, ISBN 0-582-38I67-3 (NP-7/0I)

HISTORY AND CLIMATE: MEMORIES OF THE FUTURE?

P. D. Jones et al., Eds., 2001, 295 pp., $\$ 70.00$, hardbound, Kluwer Academic/Plenum Publishers, ISBN 0-306-46589-2 (NP-3/02)

INSIDE THE HURRICANE: FACE TO FACE WITH NATURE'S DEADLIEST STORMS
Pete Davies, 2000, 264 pp., $\$ 25.00$, hardbound, Henry Holt and Company, ISBN 0-8050-6574-I (R-7/0I)

LIVING ON THE EDGE OF THE GULF: THE WEST FLORIDA AND ALABAMA COAST

David M. Bush et al., 200I, 340 pp., $\$ 22.95$,

paperbound, Duke University Press, ISBN 0-8223-

2565-9 (NP-2/02)

NOAH'S FLOOD: THE NEW SCIENTIFIC DISCOVERIES ABOUT THE EVENT THAT CHANGED HISTORY

W. Ryan and W. Pitman, 2000, 319 pp., $\$ 14.00$, paperbound, Simon and Schuster, ISBN 068485920-3 (NP-8/0I)

REGIONAL MANAGEMENT OF WATER RESOURCES

A. H. Schumann et al., Eds., 2001, 288 pp., 647.75, IAHS Press, ISBN 1-901502-51-I

(NP-2/02)
WATER RESOURCE

MANAGEMENT

C. A. Brebbia et al., Eds., 2001, 412 pp., $\$ 210.00$, hardbound, WIT Press, ISBN I-853I2880-5 (NP-I/02)

\section{TORNADOES}

SCANNING THE SKIES: A HISTORY OF TORNADO FORECASTING

Marlene Bradford. 2001 . 220 pp. \$24.95.

Hardbound. University of Oklahoma Press. ISBN 0-806I-3302-3 (R-I2/0I; NP-8/0I)

THE TORNADO: NATURE'S

ULTIMATE WINDSTORM

Thomas P. Grazulis, 2001,352 pp., \$29.95,

hardbound, University of Oklahoma, ISBN 0-806I-

3258-2 (R-I2/0I; NP-10/0I)

\section{MIETEOROLOGYY OF THE

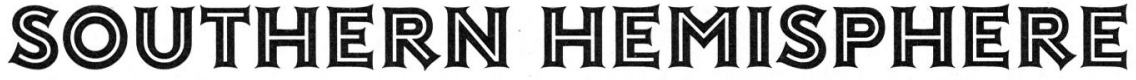

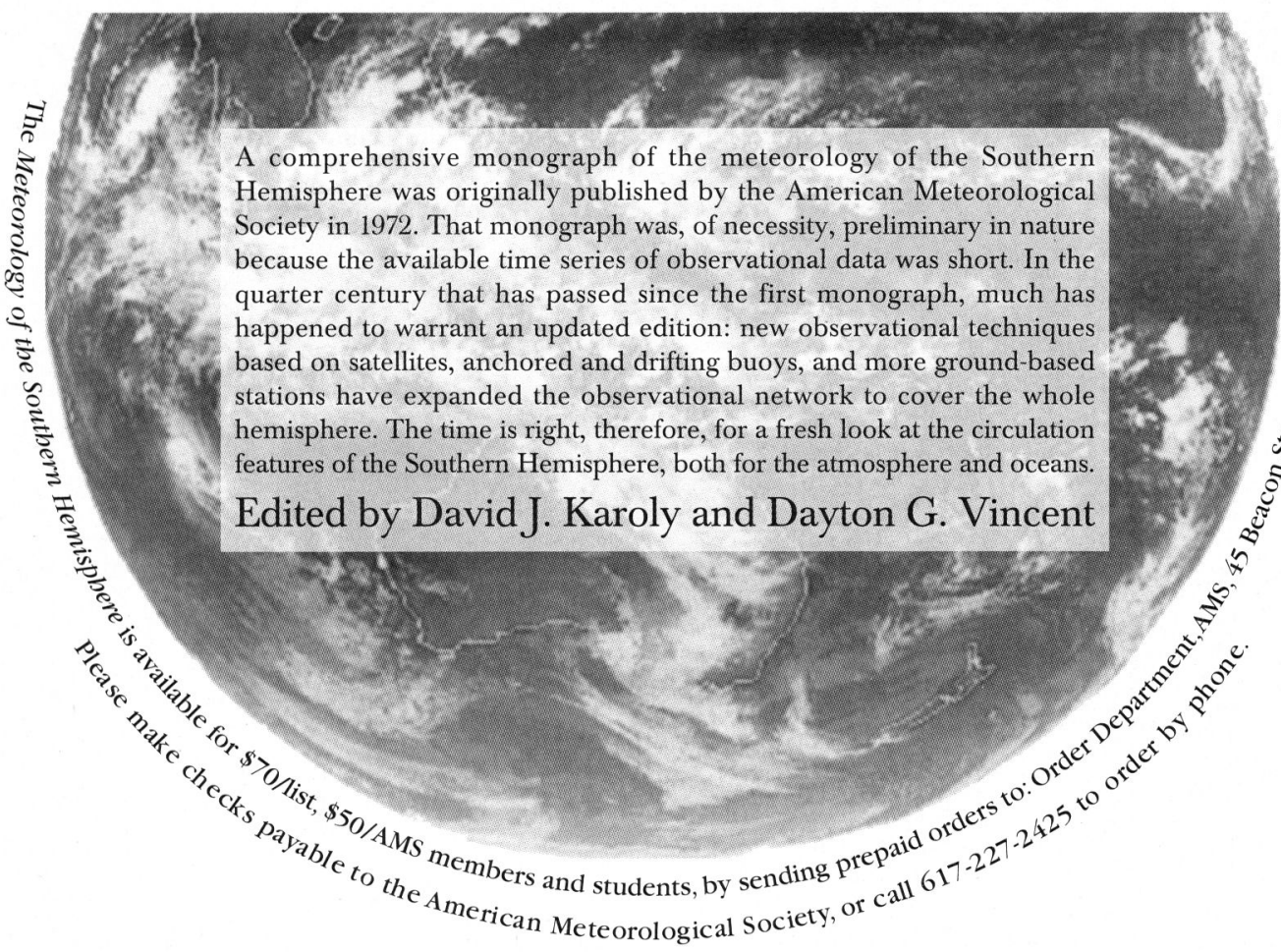




\section{GLOSSARYOF}
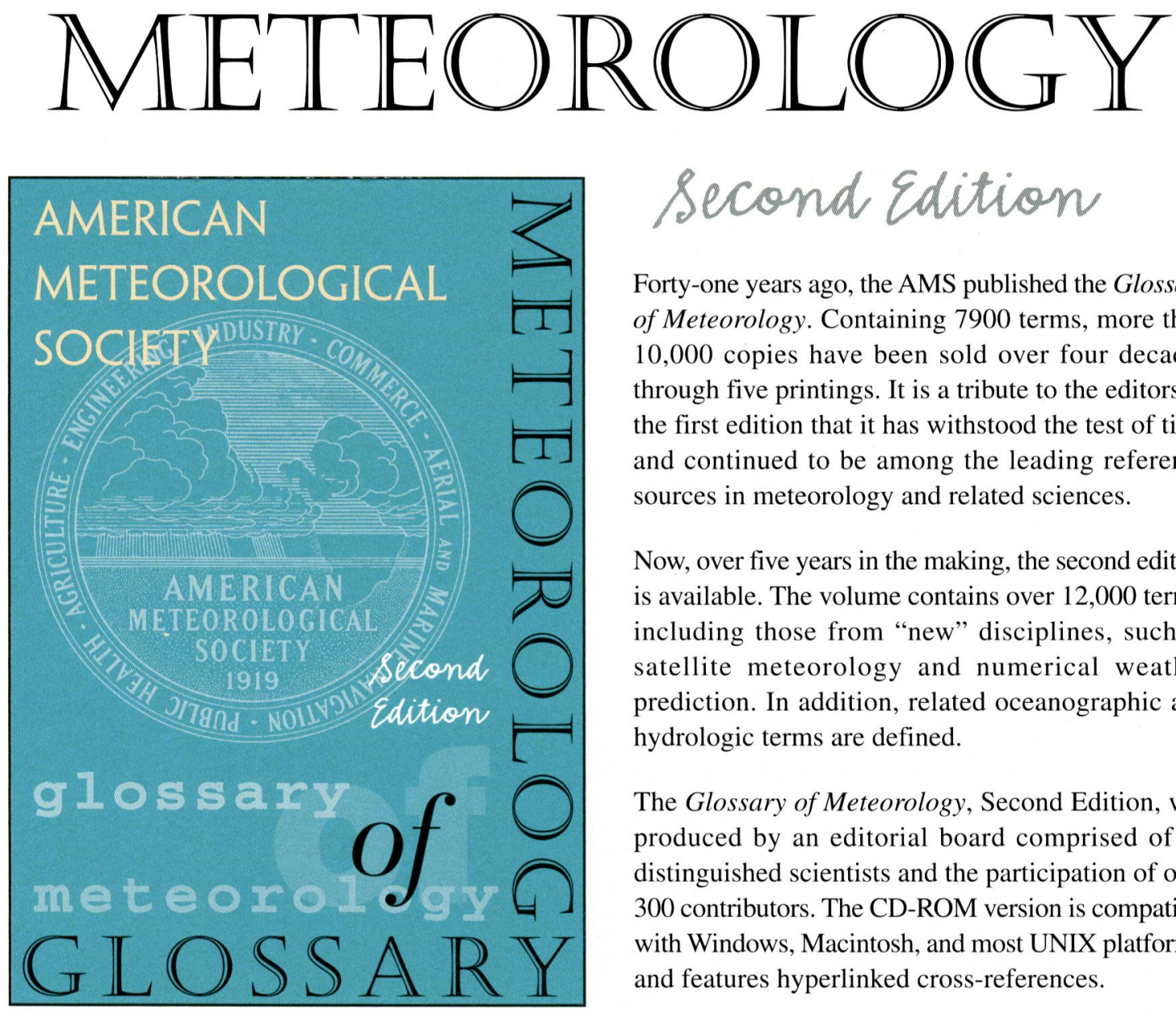

Forty-one years ago, the AMS published the Glossary of Meteorology. Containing 7900 terms, more than 10,000 copies have been sold over four decades through five printings. It is a tribute to the editors of the first edition that it has withstood the test of time and continued to be among the leading reference sources in meteorology and related sciences.

Now, over five years in the making, the second edition is available. The volume contains over 12,000 terms, including those from "new" disciplines, such as satellite meteorology and numerical weather prediction. In addition, related oceanographic and hydrologic terms are defined.

The Glossary of Meteorology, Second Edition, was produced by an editorial board comprised of 41 distinguished scientists and the participation of over 300 contributors. The CD-ROM version is compatible with Windows, Macintosh, and most UNIX platforms, and features hyperlinked cross-references.

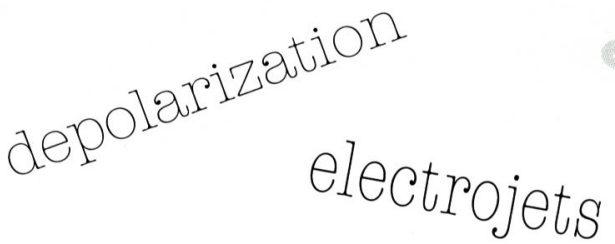

ISBN 1-878220-34-9, approx. 850 pp., hardbound. To place an order, refer to the pricing chart below and submit your prepaid orders to: Order Department, AMS, 45 Beacon Street, Boston, MA 02108-3693; call 617-227-2425 to order by phone using Visa, Mastercard, or American Express; or send e-mail to amsorder@ametsoc.org. Please make checks payable to the American Meteorological Society.
HARDBOUND BOOK

$\$ 80$ List

\$55 AMS Members

\$30 AMS Student Members
CD-ROM

$\$ 95$ List

$\$ 65$ AMS Members

\$35 AMS Student Members
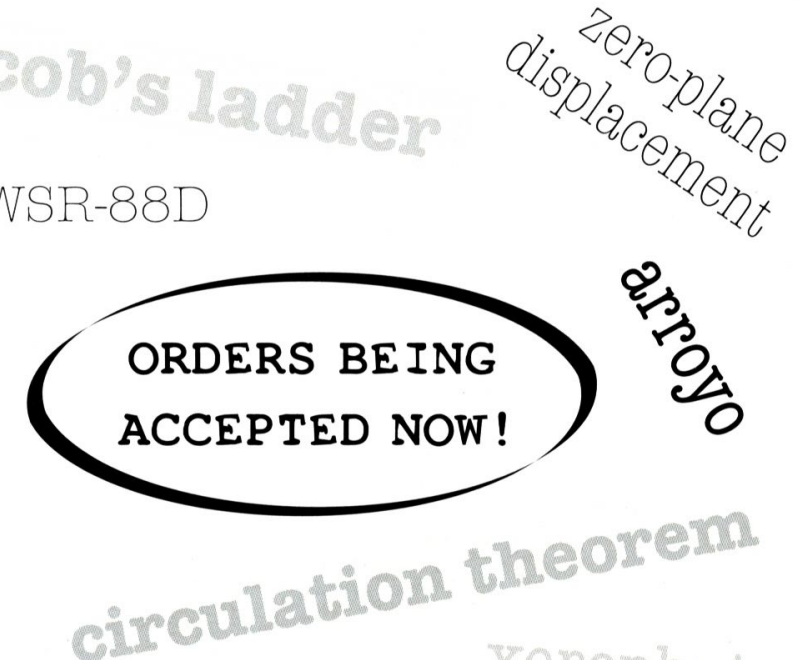
JOURNAL OF THE ATMOSPHERIC SCIENCES (ISSN 0022-4928). Vol. 59, 2002. Semi-monthly. Basic research related to the physics, dynamics, and chemistry of the atmosphere of the earth and other planets, with emphasis on the quantitative and deductive aspects of the subject.

JOURNAL OF APPLIED METEOROLOGY (ISSN 0894-8763), Vol. 41, 2002. Monthly. Applied research related to physical meteorology, cloud physics, hydrology, weather modification, satellite meteorology, boundary layer processes, air pollution meteorology (including dispersion and chemical processes), agricultural and forest meteorology, and applied meteorological

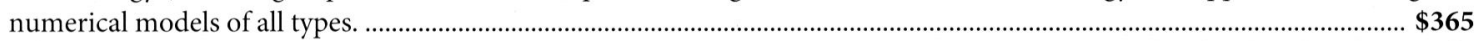

JOURNAL OF PHYSICAL OCEANOGRAPHY (ISSN 0022-3670), Vol. 32, 2002. Monthly. Research related to the physics of the ocean and to processes operating at its boundaries. Theoretical and modeling studies are welcome, especially those that are linked to observations. Papers that investigate interactions with other components of the earth system (e.g., oceanatmosphere, physical-biological and physical-chemical interactions) as well as studies of other fluid systems (e.g., lakes and laboratory tanks) are also invited, as long as their focus is on understanding the ocean. .................................................... \$445

MONTHLY WEATHER REVIEW (ISSN 0027-0644), Vol. 130, 2002. Monthly. Research related to analysis and prediction of observed and modeled circulations of the atmosphere, including technique development, data assimilation, model validation, and relevant case studies. This includes papers on numerical techniques and data assimilation techniques that apply to the atmosphere and/or ocean environment. $\$ 500$

JOURNAL OF ATMOSPHERIC AND OCEANIC TECHNOLOGY (ISSN 0739-0572), Vol. 19, 2002. Monthly. Papers describing the instrumentation and methodology used in atmospheric and oceanic research including computational techniques, methods for data acquisition, processing, and interpretation, and information systems and algorithms. ....... \$290

WEATHER AND FORECASTING (ISSN 0882-8156), Vol. 17, 2002. Bimonthly. Articles on forecasting and analysis techniques, forecast verification studies, and case studies useful to forecasters. In addition, submissions that report on changes to the suite of operational numerical models and statistical post-processing techniques, and articles that demonstrate the transfer of research results to the forecasting community.

JOURNAL OF CLIMATE (ISSN 0894-8755), Vol. 15, 2002. Semi-monthly. Articles on climate research and, therefore, welcomes manuscripts concerned with large-scale atmospheric and oceanic variability, changes in the climate system (including those caused by human activities), and climate simulation and prediction.

EARTH INTERACTIONS (ISSN 1087-3562), Vol. 6, 2002. Irregular. Publishes in the electronic medium original research in the earth system sciences with emphasis on interdisciplinary studies. Within this framework, the journal particularly encourages submissions that deal with interactions among lithosphere, hydrosphere, atmosphere, and biosphere in the context of global issues or global change. contact AMS

JOURNAL OF HYDROMETEOROLOGY (ISSN 1525-755X), Vol. 3, 2002. Bimonthly. Research related to the modeling, observing, and forecasting of processes related to water and energy fluxes and storage terms, including interactions with the boundary layer and lower atmosphere, and including processes related to precipitation, radiation, and other meteorological inputs.

BULLETIN OF THE AMERICAN METEOROLOGICAL SOCIETY (ISSN 0003-0007), Vol. 83, 2002. Monthly. The official organ of the society, devoted to editorials, topical reports to members, articles, professional and membership news, conference announcements, programs and summaries, book reviews, and Society activities.

METEOROLOGICAL \& GEOASTROPHYSICAL ABSTRACTS (ISSN 0026-1130), Vol. 53, 2002. Monthly. Abstracts of current world literature in meteorology, climatology, aeronomy, planetary atmospheres, solar-terrestrial relations, hydrology, oceanography, glaciology, cosmic rays, and radioastronomy. The abstracts of books, articles, and reprints are arranged by subject categories with extensive cross-referencing. Monthly author, subject, and geographical indexes. $M G A$ is also available as a CD-ROM and Web-based database. All inquiries for MGA and MGA's computerized database should be directed to Cambridge Scientific Abstracts.

Member prices may be obtained by calling AMS at (617) 227-2426 ext. 209 or 237. Please send prepaid orders to: Order Department, American Meteorological Society, 45 Beacon Street, Boston, MA 02108-3693. Subscriptions include postage and handling, and are accepted on a calendar-year basis only. There is an additional charge of $\$ 45$ for surface mail outside the U.S. (\$25 for Weather and Forecasting and Journal of Hydrometeorology, \$60 for the Journal of the Atmospheric Sciences and Journal of Climate), and $\$ 100$ for airmail to all countries (\$50 for Weather and Forecasting and Journal of Hydrometeorology; $\$ 200$ for the Journal of the Atmospheric Sciences and Journal of Climate). The availability and prices of back issues of AMS periodicals will be furnished upon request. 
All prices shown are list prices. For member pricing and further information about availability and ordering of AMS publications, please call 617-227-2425 or fax your inquiry to 617-742-8718, attn: AMS Order Department.

\section{BOOKS}

A Century of Weather Progress, 1970—\$20

Glossary of Meteorology, 2000; 2nd edition $-\$ 80$

Atmospheric Science and Public Policy, 1976-\$16

Workshop on the Future of National Atmospheric Research, 1977-\$16

Curricula in the Atmospheric, Oceanic, and Related Sciences, $2000-\$ 45$

Workshop on the Planetary Boundary Layer, $1980-\$ 40$

Lectures on Air Pollution and Environmental Impact Analyses, 1975; second printing, 1982-\$40

Proceedings of the First Sino-American Workshop on Mountain Meteorology, 1984-\$52.50

Proceedings of the International Symposium on the Qingha Xizang (Tibet) Plateau and Mountain Meteorology, 1986$\$ 57.50$

The above two proceedings available as a set for $\$ 88$

Atmospheric Radiation Progress and Prospects: Proceedings of the Beijing International Radiation Symposium (August 1986), $1987-\$ 55$

Probing the Atmospheric Boundary Layer, 1986— $\$ 50$

Mesoscale Meteorology and Forecasting, 1987; second printing, 1988-\$71.25

Lectures on Air Pollution Modeling, 1988-\$55

Radar in Meteorology, Battan Memorial 40th Anniversary Radar Meteorology Conference, 1990-\$106

Weather Satellites: Systems, Data, and Environmental Applications, $1990-\$ 100$

The Weather Factor, 1984-reprinted 1989—\$25

Meteorological Aspects of Emergency Response, 1990 - \$45

The Atmosphere-A Challenge: The Science of Jule Gregory Charney, 1990—\$70

Hands-on Meteorology- $\$ 26.95$

Glossary of Weather and Climate with Related Oceanic and Hydrologic Terms - \$26.95, softcover; $\$ 34.95$, hardcover

Mid-Latitude Weather Systems- $\$ 47$

The Life Cycles of Extratropical Cyclones, 1999-\$70

Distributed by AMS:

The 1938 Hurricane, $1988-\$ 22.95$

Hurricane Bob, 1992-\$15

Stories Clouds Tell, 1993-\$14.95 (Guide and slide set $-\$ 59.95$; slide set only $-\$ 54.95)^{* *}$

USA Today/AMS Transparency Set $-\$ 64.95^{* *}$

\section{METEOROLOGICAL MONOGRAPHS}

No. 4 On Atmospheric Pollution, 1951-\$22

No. 6 Thirty-Day Forecasting, 1953-\$22

No. 7 The Jet Stream, 1954-\$22

No. 8 Recent Studies in Bioclimatology, 1954-\$22

No.9 Industrial Operations under Extremes of Weather, 1957-\$22

No. 10 Interaction of Sea and Atmosphere, 1957-\$22
No. 11 Cloud and Weather Modification, 1957-\$22

Nos. 12-20

(In one volume) Meteorological Research Reviews, 1957: Review of Climatology; Meteorological Instruments; Radiometeorology; Weather Observations, Analysis and Forecasting; Applied Meteorology; Physics of the Upper Atmosphere; Physics of Clouds; Physics of Precipitation; Atmospheric Electricity-\$34

No. 21 Studies of Thermal Convection, 1959-\$22

No. 22 Topics in Engineering Meteorology, 1960-\$22

No. 23 Atmospheric Radiation Tables, 1960—\$17

No. 24 Fluctuations in the Atmospheric Inertia, 1961-\$22

No. 25 Statistical Prediction by Discriminant Analysis, 1962$\$ 22$

No. 26 The Dynamical Prediction of Wind Tides on Lake Erie, $1963-\$ 22$

No. 28 Agricultural Meteorology, 1965-\$30, paperbound; $\$ 32$, clothbound

No. 29 Scattered Radiation in the Ozone Absorption Bands at Selected Levels of a Terrestrial. Rayleigh Atmosphere, 1966-\$32, clothbound; \$30-paper

No. 30 The Causes of Climatic Change, 1968-\$30

No. 31 Meteorological Investigations of the Upper Atmosphere, $1968-\$ 28$

No. 32 On the Distribution and Continuity of Water Substance in Atmospheric Circulations, 1969-\$28

No. 34 Long-Period Global Variations of Incoming Solar Radiation, 1971 - $\$ 30$

No. 36 Alberta Hailstorms, 1973-\$28

No. 37 The Dynamic Meteorology of the Stratosphere and Mesosphere, 1975-\$45

No. 39 Solar Radiation and Clouds, 1980—\$45

No. 43 Precipitation Enhancement-A Scientific Challenge $1986-\$ 55$

No. 44 Snowstorms along the Northeastern Coast of the United States, 1990 - \$35, paperbound

No. 45 Atmospheric Processes over Complex Terrain, 1990$\$ 65$

No. 46 Representation of Cumulus Convection in Numerical Models of the Atmosphere, 1992 - $\$ 70$

No. 47 Mesoscale Modeling of the Atmosphere, 1994-\$70

No. 49 Meteorology of the Southern Hemisphere- $\$ 70$

No. 50 Severe Convective Storms, 2001-\$105

\section{HISTORICAL MONOGRAPHS AND BOOKS}

The History of American Weather (All 3 volumes-\$50) Early American Hurricanes (1492-1870), 1963-\$25

Early American Winters (1821-1870), 1967-\$25

Early American Tornadoes (1586-1870), 1970-\$25

The Thermal Theory of Cyclones: A History of Meteorological

Thought in the Nineteenth Century, 1979-\$45

Thor's Legions: Weather Support to the U.S. Air Force and Army - 1937-1987, 1990— \$70

Historical Essays on Meteorology, 1919-1995-\$65

Weathering the Storm: Sverre Petterssen, the D-Day Forecast, and the Rise of Modern Meteorology, 2001-\$70

Eyewitness: Evolution of the Atmospheric Sciences, 2001-\$70 Reflections: A Memoir, 2001-\$70 


\section{CONFERENCE PREPRINTS/PROCEEDINGS}

Ninth Conference on Aerospace and Aeronautical Meteorology, 1983-\$30

21st Conference on Radar Meteorology, 1983-\$52

Ninth Conference on Probability and Statistics in Atmospheric Sciences, 1985-\$40

23rd Conference on Radar Meteorology and Conference on Cloud Physics and Papers from Joint Sessions, 3 Vols., 1986-\$100

Third Conference on Mesoscale Processes, 1987-\$45

Fourth Conference on Mountain Meteorology, 1987-\$40

18th Conference on Agricultural and Forest Meteorology and Eighth Conference on Biometeorology and Aerobiology, $1987-\$ 40$

10th Conference on Probability and Statistics, 1987-\$40

4th International Conference on Interactive Information Processing for Meteorology, Oceanography, Hydrology, $1988-\$ 55$

15th Conference on Severe Local Storms, 1988-\$55

Palmen Symposium on Extratropical Cyclones and Their Role in the General Circulation of the Atmosphere, 1988 - \$55

Fifth International Conference on Interactive Information and Processing Systems for Meteorology, Oceanography, and Hydrology, 1989-\$55

Symposium on the Role of Clouds in Atmospheric Chemistry and Global Climate, 1989-\$55

19th Conference on Agricultural and Forest Meteorology/9th Conference on Biometeorology and Aerobiology, 1989-\$55

Sixth Conference on Applied Climatology, 1989-\$55

24th Conference on Radar Meteorology, 1989-\$66

Fourth Conference on Satellite Meteorology and Oceanography, 1989-\$55

11th Conference on Probability and Statistics, 1989-\$55

Third International Conference on Southern Hemisphere Meteorology and Oceanography, 1989-\$55

Sixth International Conference on Interactive Info. and Processing Systems for Meteorology, Oceanography, and Hydrology, $1990-\$ 55$

Ninth Symposium on Turbulence and Diffusion, 1990-\$55

Fourth Conference on Mesoscale Processes, 1990— \$55

Seventh Conference on Atmospheric Radiation, 1990-\$55

Conference on Cloud Physics, 1990-\$60

Fifth Conference on Satellite Meteorology, 1990 - \$55

16th Conference on Severe Local Storms/Conference on Atmospheric Electricity, 1990-\$55

Eighth Conference on Hydrometeorology, 1990 - \$55

Seventh International Conference on Interactive Information and Processing Systems for Meteorology, Oceanography, and Hydrology, 1991-\$55

Seventh Symposium on Meteorological Observations and Instrumentation/Special Session on Laser Atmospheric Studies, 1991-\$55

Seventh Joint Conference on Applications of Air Pollution Meteorology with AWMA, 1991—\$55

First International on Winter Storms Symposium, 1991-\$55

19th Conference on Hurricanes and Tropical Meteorology, $1991-\$ 55$

Fifth Conference on the Meteorology and Oceanography of the Coastal Zone, 1991-\$55

25th International Conference on Radar Meteorology, 1991 - \$71

Fourth International Conference on Aviation Weather Systems, $1991-\$ 61$

20th Conference on Agricultural and Forest Meteorology, 1991$\$ 55$
Tenth Conference on Biometeorology and Aerobiology, Special Session on Hydrometeorology, 1991-\$65

Seventh Conference on Applied Climatology, 1991-\$55

Fifth Conference on Climate Variations, 1991 - \$55

Eighth Conference on Atmos. and Oceanic Waves and Stability, $1991-\$ 55$

Ninth Conference on Numerical Weather Predicition, 1991-\$66

Eighth International Conference on Interactive Information and Processing Systems for Meteorology, Oceanography, and Hydrology, 1992-\$55

Eighth Conference on the Meteorology of the Middle Atmos., 1992-\$55

Sixth Conference on Satellite Meteorology and Oceanography, $1992-\$ 55$

Symposium on Planned and Inadvertent Weather Modification, $1992-\$ 55$

12th Conference on Probability and Statistics, 1992-\$55

10th Symposium on Turbulence and Diffusion, 1992-\$55

Sixth Conference on Mountain Meteorology, 1992-\$55

Third Conference on Polar Meteorology and Oceanography, 1992-\$55

Symposium on Weather Forecasting, 1992-\$55

Ninth International Conference on Interactive Info. and Proc. Systems for Meteorology, Oceanography, and Hydrology/ Special Program on GOES, 1993-\$55

Eighth Symposium on Meteorological Observations and Instrumentation/Special Session on Ultraviolet Measurements and Profiling of Water Vapor in the Free Troposphere and Stratosphere, 1993-\$55

Eighth Conference on Applied Climatology, 1993-\$55

Fourth Sym. on Global Climate Change Studies, 1993-\$55

Conference on Hydroclimatology: Land/Surface/Atmosphere Interactions on Global and Regional Scales, 1993-\$55

Fourth International Conference on Southern Hemisphere Meteorology and Oceanography, 1993-\$55

26th Conference on Radar Meteorology, 1993-\$60

Fifth International Conference on Aviation Weather Systems, 1993-\$55

17th Conference on Severe Local Storms/Conference on Atmospheric Electricity, 1993- $\$ 60$

Eighth Conference on Atmospheric Radiation, 1994-\$55

Eighth Joint Conference on the Application of Air Pollution Meteorology with the Air and Waste Management Association, 1994-\$55

Sixth Conference on Climate Variations, 1994-\$55

Fifth Symposium on Global Change Studies/Symposium on the Global Electrical Circuit, Global Change, and the Meteorological Applications of Lightning Information, 1994-\$55

Conference on Atmospheric Chemisty, 1994-\$55

Third Symposium on Education, 1994-\$55

The Great Flood of 1993, 1994-\$15

21st Conference on Agricultural and Forest Meteorology/11th Conference on Biometeorology and Aerobiology, 1994-\$55

Seventh Conference on Satellite Meteorology and Oceanography, 1994-\$55

10th Conference on Numerical Weather Prediction, 1994-\$55

Sixth Conference on Mesoscale Processes, 1994-\$55

Second International Conference on Air-Sea Interaction and Meteorology and Oceanography of the Coastal Zone, $1994-\$ 55$

Ninth Conference on Applied Climatology, 1995-\$55

Sixth Symposium Global Change Studies, 1995-\$55

Sixth Conference on Aviation Weather Systems, 1995—\$55 
Fourth Conference on Polar Meteorology and Oceanography, $1995-\$ 55$

Conference on Hydrology, 1995-\$55

Symposium on Reg. of Sea Surface Temps and Warming of

Tropical Ocean-Atmosphere Systems, 1995-\$55

Fourth Symposium on Education, 1995-\$55

11th Symposium on Boundary Layers and Turbulence, 1995-\$55

Ninth Symposium on Meteorological Observation and Instrumentation, 1995-\$55

10th Conference on Atmospheric and Oceanic Waves and Stability, 1995-\$55

Seventh Conference on Mountain Meteorology, 1995-\$55

27th Conference on Radar Meteorology, 1995-\$55

Symposium on Environmental Applications, 1996-\$65

13th Conference on Planned and Inadvertent Weather Modification, 1996-\$65

12th International Conference on Interactive Information and Processing for Meteorology, Oceanography, and Hydrology, $1996-\$ 65$

Ninth Joint Conference on Applications of Air Pollution Meteorology, 1996-\$65

Eighth Conference on Satellite Meteorology, 1996-\$65

Eighth Conference on Air-Sea Interaction/Symposium on the Global Ocean-Atmosphere-Land System (GOALS), 1996$\$ 65$

Seventh Symposium on Global Change Studies, 1996-\$65

Fifth Symposium on Education, 1996-\$65

Conference on Coastal Oceanic and Atmospheric Prediction, $1996-\$ 65$

13th Conference on Probability and Statistics, 1996-\$65

15th Conference on Weather Analysis and Forecasting, 1996-\$65

11 th Conference on Numerical Weather Prediction, 1996-\$65

Seventh Conference on Mesoscale Processes, 1996-\$65

Special Symposium on Boundary Layer Turbulence, 1997-\$65

13th Conference on Interactive Information and Processing for

Meteorology, Oceanography, and Hydrology, 1997-\$65

13th Conference on Hydrology, 1997-\$65

Ninth Conference on Atmospheric Radiation, 1997-\$65

Eighth Conference on Global Change Studies, 1997-\$65

Seventh Conference on Aviation, Range, and Aerospace Meteorology, 1997-\$65

Seventh Conference on Climate Variations, 1997-\$65

Third Conference on Atmospheric Chemistry, 1997-\$65

First Symposium on Integrated Observing Systems, 1997-\$65

Fifth International Conference on Southern Hemisphere

Meteorology and Oceanography, 1997-\$65

22nd Conference on Hurricanes and Tropical Meteorology, $1997-\$ 65$

11th Conference on Atmospheric and Oceanic Fluid Dynamics, $1997-\$ 65$

12th Symposium on Boundary Layers and Turbulence, 1997-\$65

28th Conference on Radar Meteorology, 1997-\$65

10th Conference on Applied Climatology, 1997-\$65

16th Conference on Weather Analysis and Forecasting/

Symposium on Research Foci of the U.S. Weather Research

Program, 1998-\$65

14th International Conference on Interactive Information and

Processing Systems for Meteorology, Oceanography, and

Hydrology, 1998-\$65

14th Conference on Probability and Statistics, 1998 -\$65

12th Conference on Numerical Weather Prediction, 1998-\$65

10th Joint Conference on Applications of Air Pollution

Meteorology, 1998-\$65 10th Symposium on Meteorological Observations and Instrumentation, 1998-\$65

Ninth Symposium on Global Change Studies/Namias Symposium on Status and Prospects for Climate Prediction, 1998-\$65

Ninth Conference on Interaction of the Sea and Atmosphere, $1998-\$ 65$

Seventh Symposium on Education, 1998- $\$ 65$

Second Symposium on Fire and Forest Meteorology, 1998-\$65

Second Symposium on Integrated Observing Systems, 1998—\$65

Second Conference on Coastal Oceanography and Atmospheric Prediction, 1998-\$65

First Conference on Artificial Intelligence, 1998-\$65

Special Symposium on Hydrology, 1998-\$65

Symposium on Tropical Cyclone Intensity Change, 1998-\$65

Ninth Conference on Satellite Meteorology and Oceanography, $1998-\$ 80$

Eighth Conference on Mountain Meteorology, 1998-\$65

AMS Conference on Cloud Physics/14th Conference on Planned and Inadvertent Weather Modification, 1998-\$65

19th Conference on Severe Local Storms, 1998-\$65

23rd Conference on Agricultural \& Forest Meteorology/13th Conference on Biometeorology and Aerobiology, 1998-\$65

23rd Conference on Hurricane and Tropical Meteorology, 1999$\$ 65$

15th International Conference on Interactive Information \& Processing Systems for Meteorology, Oceanography, and Hydrology, 1999-\$65

14th Conference on Hydrology, 1999-\$65

13th Symposium on Boundary Layers and Turbulence, 1999—\$65

11th Conference on Applied Climatology, 1999-\$65

10th Symposium on Global Change Studies, 1999-\$65

Eighth Conference on Aviation, Range and Aerospace Meteorology, 1999-\$65

Eighth Symposium on Education, 1999-\$65

Fifth Conference on Polar Meteorology and Oceanography, 1999-\$65

Third Symposium on Integrated Observing Systems, 1999-\$65

Symposium on Interdisciplinary Issues in Atmospheric Chemistry, 1999-\$65

Eighth Conference on Mesoscale Processes, 1999-\$65

12th Conference on Atmospheric and Oceanic Fluid Dynamics, 1999-\$65

10th Conference on Atmospheric Radiation, 1999-\$65

29th Conference on Radar Meteorology, 1999-\$65

17th Conference on Weather Analysis and Forecasting/13th

Conference on Numerical Weather Prediction, 1999-\$65

Eighth Conference on Climate Variations, 1999-\$65

Third Conference on Coastal Atmospheric and Oceanic Prediction, 1999-\$65

Second Symposium on Environmental Applications, 2000-\$75 16th International Conference on Interactive Information and Processing for Meteorology, Oceanography, and Hydrology, 2000-\$75

15th Conference on Hydrology, 2000-\$75

11th Joint Conference on Applications of Air Pollution Meteorology/Symposium on Atmospheric Chemistry Issues in 21st Century, 2000-\$75

11th Symposium on Global Change Studies/Symposium on Lidar Atmospheric Monitoring, 2000—\$75

10th Conference on Satellite Meteorology, 2000-\$75

Ninth Symposium on Education, 2000-\$75

Fourth Symposium on Integrated Observing Systems, 2000—\$75

Third Symposium on Fire \& Forest Meteorology, 2000 - \$75 
Second Conference on Artificial Intelligence, 2000— \$75

11th Conference on the Middle Atmosphere (abstracts only), $2000-\$ 65$

15th Conference on Probability \& Statistics in the Atmospheric Sciences/12th Conference on Applied Climatology, 2000-\$75

24th Conference on Hurricanes \& Tropical Meteorology/10th Conference on Interaction of the Sea \& Atmospheric, 2000$\$ 75$

14th Symposium on Boundary Layer \& Turbulence, 2000-\$75

Ninth Conference on Mountain Meteorology, 2000—\$75

24rd Conference on Agricultural \& Forest Meteorology/14th Conference on Biometeorology \& Aerobiology/Third Symposium on Urban Environment, 2000-\$75

20th Conference on Severe Local Storms, 2000-\$75

Ninth Conference on Aviation, Range and Aerospace Meteorology, 2000-\$75

Symposium on Climate Variability, the Oceans, and Societal Impacts, 2001-\$75

Symposium on Precipitation Extremes: Prediction, Impacts and Responses, 2001 $-\$ 75$

17th International Conference on Interactive Information \& Processing

Systems for Meteorology, Oceanography, \& Hydrology, 2001$\$ 75$

15th Conference on Planned \& Inadvertent Weather Modification/ Millennium Symposium on Atmospheric Chemistry, 2001-\$75

12th Symposium on Global Change and Climate Variations, $2001-\$ 75$

11th Symposium on Meteorological Observations \& Instrumentation, 2001-\$75

10th Symposium on Education, 2001-\$75

Fifth Symposium on Integrated Observing Systems, 2001 - \$75

6th Conference on Polar Meteorology \& Oceanography/11th

Conference on Interactions of the Sea \& Atmosphere, 2001 $\$ 75$

13th Conference on Atmospheric \& Oceanic Fluid Dynamics, $2001-\$ 75$

30th International Conference on Radar Meteorology, 2001 - \$75

18th Conference on Weather Analysis \& Forecasting/14th Conference on Numerical Weather Prediction, 2001 - \$75

9th Conference on Mesoscale Processes, 2001 - \$75

11th Conference on Satellite Meteorology and Oceanography, $2001-\$ 75$

4th Conference on Coastal Atmosphere and Oceanic Prediction, $2001-\$ 75$

4th Symposium on Fire and Forest Meteorology, 2001 - \$75

Symposium on Observations, Data Assimilation, and Probabilistic Prediction, 2002 - \$75

3rd Symposium on Environmental Applications: Facilitating the Use of Environmental Information, 2002 - \$75

18 th International Conference on Interactive Information \& Processes/System for Meteorology, Oceanography, and Hydrology, 2002 - \$75

16th Conference on Probability and Statistics in the Atmospheric Sciences, 2002 - $\$ 75$

16th Conference of Hydrology, 2002 - \$75

13th Symposium on Global Change \& Climate Variations, 2002 $\$ 75$ 11th Symposium on Education, 2002 - $\$ 75$

6th Symposium on Integrated Observing Systems, 2002 - \$75

4th Conference on Atmospheric Chemistry: Urban, Regional, and

Global Scale Impacts of Air Pollutants, 2002 - \$75

\section{ABSTRACTS}

Meteorological and Geoastrophysical Abstracts (Monthly)

- All inquiries regarding MGA should be directed to Cambridge Scientific Abstracts, 7200 Wisconsin Ave., Bethesda, MD 20814; phone: 301-961-6700; fax: 301-9616720; email: Service@csa.com

\section{INDEXES}

Meteorological and Geoastrophysical Abstracts (Annual Indexes) Meteorological and Geoastrophysical Abstracts (Cumulative Indexes)

- All inquiries regarding MGA should be directed to Cambridge Scientific Abstracts, 7200 Wisconsin Ave., Bethesda, MD 20814; phone: 301-961-6700; fax: 301-9616720; email: Service@csa.com

Journal of Physical Oceanography, Cumulative Index, Vols. 1-25: Print-\$40; Electronic- $\$ 50$

\section{CD-ROM}

Distributed by the American Meteorological Society, 45 Beacon Street, Boston, MA 02108-3693

All 1993 preprint volumes on CD-ROM-\$255 (Specify MS-DOS or Macintosh)

All 1994 preprint volumes on CD-ROM- $\$ 255$ (Specify MS-DOS or Macintosh)

All 1995 preprint volumes on CD-ROM-\$255 (Specify MS-DOS, Macintosh, Windows, or UNIX)

All 1996 preprint volumes on CD-ROM-\$255 (Specify MS-DOS, Macintosh, Windows, or UNIX)

All 1997 preprint volumes on CD-ROM-\$255 (Specify MS-DOS, Macintosh, Windows, or UNIX)

All 1998 preprint volumes on CD-ROM-\$255 (Specify MS-DOS, Macintosh, Windows, or UNIX)

All 1999 preprint volumes on CD-ROM-\$255 (Specify MS-DOS, Macintosh, Windows, or UNIX)

All 2000 preprint volumes on CD-ROM-\$255 (Specify MS-DOS, Macintosh, Windows, or UNIX)

All 2001 preprint volumes on CD-ROM-\$255 (Specify MS-DOS, Macintosh, Windows, or UNIX)

The AMS 1996 Journal/Bulletin Archive CD-ROM-\$505 The AMS 1997 Journal/Bulletin Archive CD-ROM-\$505 The AMS 1998 Journal/Bulletin Archive CD-ROM-\$505 The AMS 1999 Journal/Bulletin Archive CD-ROM-\$505 The AMS 2000 Journal/Bulletin Archive CD-ROM-\$505 The AMS 2001 Journal/Bulletin Archive CD-ROM-\$505

Glossary of Meteorology, 2000, 2nd edition, CD-ROM - \$95 
All prices listed below are quoted in U.S. dollars. Postage and handling is included in the price. (Availability and prices are subject to change without notice.) Orders and inquiries from residents of the U.S. and Canada should be directed to: American Meteorological Society, Attn: WMO Publications Center, 45 Beacon Street, Boston, MA 02108, U.S.A. Residents of all other countries should direct orders and inquiries to: World Meteorological Organization, Publications Sales Unit, Case Postale 2300, CH-1211 Geneva 2, Switzerland.

Remittance must accompany all orders; only after receipt of payment will the order be processed. Payment from Canadian clients must be made by a draft on a U.S. bank or by international money order. Checks or money orders should be made payable to the AMS in U.S. dollars.

\section{WMO Bulletin-Quarterly Subscription ${ }^{+}$}

\begin{tabular}{ccc}
$\begin{array}{c}\text { Number } \\
\text { of years }\end{array}$ & Surface mail & Airmail \\
\hline 1 & $\$ 60$ & $\$ 85$ \\
2 & $\$ 110$ & $\$ 150$ \\
3 & $\$ 145$ & $\$ 195$
\end{tabular}

+Subscriptions to WMO Bulletin are accepted on calendar year basis.

WMO 5-Composition of WMO-Quarterly Subscription

Number Surface mail

of years

$\begin{array}{cr}1 & \$ 125 \\ 2 & \$ 225 \\ 3 & \$ 300 \\ \text { Single issue } & \$ 35\end{array}$

+Subscriptions to WMO 5 are accepted on calendar year basis.

\section{ATLASES}

Climatic Atlas of Europe. Volume I: Maps of Mean Temperature and Precipitation- $\$ 177$

Climatic Atlas of South America. Volume I: Maps of Mean Temperature and Precipitation $-\$ 202$

Climatic Atlas of North and Central America. Volume I: Maps of Mean Temperature and Precipitation $-\$ 177$

International Cloud Atlas, Abridged Edition, 1956-\$52
407 International Cloud Atlas

Vol. I, Manual on the Observation of Clouds and Other Meteors, 1975-\$52

Vol. II, Plates, 1987— $\$ 83$

659 Marine Cloud Album, 1987-\$25

\section{BASIC DOCUMENTS}

15 Basic Documents No. 1-(excluding Technical Regula tions), 4th Edition, 1999-\$45

60 Basic Documents No. 3-Agreements and Working Arrangements With Other International Organizations, $1988-\$ 35$

\section{TECHNICAL REGULATIONS}

49 Technical Regulations-Basic Documents No. 2 Vol. I, General Meteorological Standards and Recom mended Practices, 1988 edition $-\$ 63$

Vol. II, Meteorological Service for International Air Navigation, 2001 edition $-\$ 70$

Vol. III, Hydrology, 1988 edition-\$71

\section{WEATHER REPORTING, STATIONS, DATA PROCESSING, AND TRANSMISSION}

9 Weather Reporting

Vol. A, Observing Stations: Basic Volume $-\$ 100$ Subscription to Supplement Service (Semi-annual): Surface mail $\$ 180$ Airmail $\$ 210$

Vol. B, Data Processing: Basic Volume $-\$ 62$; Cover $-\$ 22$

Vol. C1, Catalogue of Meteorological Bulletins - $\$ 72$ Subscription to Supplement Service (Bimonthly): Surface mail \$135 Airmail $\$ 160$

Vol. C2, Transmissions Schedules $-\$ 72$ Subscription to Supplement Service (Bimonthly): Surface mail \$55 Airmail $\$ 80$

Vol. D Information for Shipping: Basic Volume $-\$ 183$

\section{OPERATION MANUALS}

\section{Manual on Codes}

Vol. I International Meteorological Codes

Part A-Alphanumeric-w/cover, \$130 (1995 edition)

Part B-Binary-w/cover, $\$ 120$ (2001 edition)

Vol. ll Regional, 1998 edition-w/cover, \$128

386 Manual on the Global Telecommunication System,

1992-\$157 (w/cover)

Vol. I Global Aspects

Vol. II Regional Aspects 
411 Information on Meteorological and Other Environ mental Satellites, 1994-\$55 w/binder

485 Manual on the Global Data Processing System (Vol. I and II, one cover), 1992-\$66

Vol. I Global Aspects, 1977

Vol. II Regional Aspects, 1980

544 Manual on the Global Observing System (Vol. I and II, one cover), 1981-\$32; cover $-\$ 17$

558 Manual on Marine Meteorological Services, 1990— \$52

\section{GUIDES}

8 Guide to Meteorological Instruments and Observing Practices, 1996- $\$ 155$

100 Guide to Climatological Practices, 2nd edition, 1983-\$44

134 Guide to Agricultural Meteorological Practices, 2nd edition, 1981-\$34

168 Guide to Hydrological Practices, 1994-\$105

305 Guide on the Global Data Processing System, 1993 — \$75

471 Guide to Marine Meteorological Services, 4th edition, $2001-\$ 45$

488 Guide on the Global Observing System, 1989-\$47

623 Guide to the IGOSS Data Processing and Services System, 1983-\$20

634 Guidelines for Computerized Data Processing in Operational Hydrology and Land and Water Management, 1985-\$39

636 Guide on the Automation of Data Processing Centers, $1998-\$ 55$

702 WMO Guide to Wave Analysis and Forecasting, 1998 - \$69

731 Guide to Meteorological Observation and Information Distribution Systems at Aerodromes, 1990—\$29

732 Guide to Practices for Meteorological Offices Serving Aviation, 1990-\$31

781 Guide to Applications of Marine Climatology, 1994-\$46

788 Guide on the WWW Data Management, 1993-\$27

834 Guide to the Public Weather Services Practices, 1999, 2nd edition-\$59

842 Guide to the Provision of Meteorological Service for International Helicopter Operations, 1996-\$20

904 Guide on Aeronautical Meteorological Services Cost Recovery, 1999-\$21

\section{TRAINING MANUALS}

240 Compendium of Training Facilities for Meteorology and Operational Hydrology, 1996-\$65

258 Guidelines for Education and Training of Personnel in Meteorology and Operational Hydrology, 3rd edition, $1984-\$ 44$

266 Compendium of Lecture Notes for Training Class IV Meteorological Personnel:

Vol. I, Earth Science, 1970-\$28

Vol. II, Meteorology, 2nd edition, 1984-\$52

364 Compendium of Meteorology for use by Class I and II Meteorological Personnel

Vol. II: Part 1: General Hydrology, 1977—\$20

Part 3: Marine Meteorology, 1979-\$21

Part 4: Tropical Meteorology, 1979-\$45

Part 5: Hydrometeorology, 1985-\$24

Part 6: Air Chem. and Air Pollut. Meteorol.,1985$\$ 31$
434 Compendium of Lecture Notes in Marine Meteorology for Class III and Class IV Personnel, 1991-\$42

551 Lecture Notes for Training Class II and Class III Agricultural Meteorological Personnel, 2001-\$61

593 Lecture Notes for Training Class IV Agricultural Meteorological Personnel, 1982-\$24

622 Compendium of Lecture Notes on Meteorological Instruments for Training Class III and Class IV Meteorological Personnel, 1986

Vol. I: Part 1: Meteorological Instruments; Part 2: Meteorological Instrument Maintenance Workshops, Calibration Laboratories and Routines-\$44

Vol. II: Part 3: Basic Electronics for the Meteorologist-\$42 669 Workbook on Numerical Weather Prediction for the Tropics for the Training of Class I and Class II Meteorological Personnel, 1986-\$44

701 Mesometeorology and Short-Range Forecasting, 1990—\$20

726 Compendium of Lecture Notes in Climatology for Class III and Class IV Personnel, 1992-\$39

\section{OPERATIONAL HYDROLOGY REPORTS}

332 Manual for Estimation of Probable Maximum Precipita tion, O.H.R. 1; 1986-\$38

341 Benefit and Cost Analysis of Hydrological Forecasts. A State-of-the-Art Report, O.H.R. 3; 1973-\$20

429 Intercomparison of Conceptual Models Used in Operational Hydrological Forecasting, O.H.R. No. 7; 1975$\$ 33$

433 Hydrological Network Design and Information Transfer. Proceedings of the International Seminar, Newcastle upon Tyne, U.K., August 1974, O.H.R. 8; 1976-\$41

461 Casebook of Examples of Organization and Operation of Hydrological Services, O.H.R. 9; 1977—\$32

513 Applications of Remote Sensing to Hydrology, O.H.R. 12; 1979-\$20

519 Manual on Stream Gauging (2-volume set in one binder), O.H.R. 13; 1980-\$66

559 Hydrological Data Transmission, O.H.R. 14; 1981-\$20

560 Selection of Distribution Types for Extremes of Precipita tion, O.H.R. 15; 1981 - \$20

561 Measurement of River Sediments, O.H.R. 16; 1981-\$20

576 Case Studies of National Hydrological Data Banks (Planning, Development and Organization), O.H.R. 17; $1981-\$ 20$

577 Flash Flood Forecasting, O.H.R. 18; 1981- \$20

580 Concepts and Techniques in Hydrological Network Design, O.H.R. 19; 1982-\$20

587 Long-Range Water-Supply Forecasting, O.H.R. 20; 1982-\$20

589 Methods of Correction for Systematic Error in Point Precipitation Measurement for Operational Use, O.H.R. 21; 1982-\$20

635 Casebook on Operational Assessment of Areal Evapora tion, O.H.R. 22; 1985-\$28

646 Intercomparison of Models of Snowmelt Runoff, O.H.R. 23; 1986-\$56

650 Level and Discharge Measurement Under Difficult Conditions, O.H.R. 24; 1986-\$20

655 Tropical Hydrology, O.H.R. 25; 1987-\$20 
Methods of Measurement and Estimation of Discharges at Hydraulic Structures, O.H.R. 26; 1986-\$20

680 Manual on Water Quality Monitoring, O.H.R. 27, 1988$\$ 27$

Hydrological Information Referral Service-

INFOHYDRO Manual, O.H.R. 28, 1994-\$137

686 Manual on Operational Methods for Measurements of Sediment Transport, O.H.R. 29; 1989-\$22

704 Hydrological Aspects of Combined Effects on Storm Surges and Heavy Rainfall on River Flow, O.H.R. 30; $1988-\$ 20$

Management of Groundwater Observation Programmes, O.H.R. 31-\$23

717 Cost-Benefit Assessment Techniques and User Require ments for Hydrological Data, O.H.R. No. 32-\$26

718 Statistical Distributions for Flood Frequency Analysis, O.H.R., No. 33-\$22

740 Hydrological Models for Water-Resources Systems Design and Operation, O.H.R., No. 34-\$23

749 Snow Cover Measurements and Areal Assessment of Precipitation and Soil Moisture, O.H.R. 35, 1991— \$45

754 Hydrological Aspects of Accidental Pollution of Water Bodies, O.H.R. 37, 1992- $\$ 40$

773 Remote Sensing for Hydrology Process Prospects, O.H.R. $36,1992-\$ 25$

779 Simulated Real-time Intercomparison of Hydrological Models, O.H.R. 38, 1992-\$41

803 Land Surface Processes in Large-Scale Hydrology, O.H.R. $40-\$ 25$

804 Applications of Remote Sensing by Satellite, Radar and Other Methods of Hydrology, O.H.R. 39-\$21

806 An Overview of Selected Techniques for Analysing Surface Water Data Networks, O.H.R. 41-\$20

884 Current operational applications of remote sensing in hydrology, 1998-\$25

885 Areal Modelling in Hydrology Using Remote Sensing, O.H.R. $44-\$ 20$

886 Contaminants in Rivers \& Streams, O.H.R. 45-\$20

887 Precipitation estimation and forecasting, 1998 - \$27

\section{SPECIAL ENVIRONMENT REPORTS}

455 The Quantitative Evaluation of the Risk of Disaster from Tropical Cyclones, S.E.R. No. 8; 1976-\$60

496 Systems of Evaluating and Predicting the Effects of Weather and Climate on Wildland Fires, S.E.R. 11; 1978$\$ 18$

647 Lectures Presented at the WMO Technical Conference on Observation and Measurements of Atmospheric Contaminants (TECOMAC), S.E.R. 16; 1985-\$72

\section{MARINE SCIENCE AFFAIRS}

750 Guide to Moored Buoys and Other Ocean Data Acquisi tions Systems, M.S.A. No. 16; 1990 - \$20

\section{TECHNICAL NOTES}

243 Meteorology and Grain Storage, T.N. 101; 1990 ed. - \$21

319 Dispersion and Forecasting of Air Pollution, T.N. 121; $1972-\$ 29$

415 On the Statistical Analysis of Series of Observations, T.N. $143 ; 1990-\$ 57$
487 Techniques of Frost Prediction and Methods of Frost and Cold Protection, T.N. 157; 1978—\$45

495 Handbook of Meteorological Forecasting for Soaring Flight, T.N. 158; 1993— \$29

498 Soya Bean and Weather, T.N. 160; 1978 - \$29

531 Quantitative Meteorological Data from Satellites, T.N. 166; $1979-\$ 29$

562 Weather and Airborne Organisms, T.N. 173; 1980-\$21

557 Meteorological aspects of the utilization of solar radiation as an energy source, 1981 - \$45

620 Weather-Based Mathematical Models for Estimating Development and Ripening of Crops, T.N. 180; 1983-\$21

625 Use of Radar in Meteorology, T.N. 181; 1985-\$35

629 Analysis of Data from International Experiments on Lucerne, T.N. 182; 1985-\$26

633 Land Use and Agro-System Management Under Severe Climatic Conditions, T.N. 184; 1985-\$30

641 Meteorological Observations using NAVAID Methods, T.N. $185 ; 1985-\$ 20$

662 Land Management in Arid and Semi-Arid Areas, T.N. 186; $1989-\$ 35$

665 Guidance Material on the Calculation of Climatic Parameters Used for Building Purposes, T.N. 187; 1992$\$ 32$

672 Applications of Meteorology to Atmospheric Pollution Problems, T.N. 188; 1987-\$20

679 Contribution of Satellite Data and Service to WMO Programs in the Next Ten Years, T.N. 189; 1987-\$39

684 Weather and Climate and Animal Performance, T.N. 190; $1988-\$ 31$

685 Animal Health and Production at Extremes of Weather, T.N. 191; 1988-\$34

687 Agrometeorological Aspects of Operational Crop Protection, T.N. 192; 1988-\$30

703 Agroclimatology of the Sugar Cane Crop, T.N. 193; $1989-\$ 23$

759 Measurement of Air Temperature and Humidity, T.N. $194 ; 1991-\$ 20$

770 Methods of Interpreting Numerical Weather Prediction Output for Aeronautical Meteorology, T.N. 195; 1999-\$45

802 Climate Variability, Agriculture, and Forestry, T.N. 196$\$ 35$

839 Agrometeorology of Grass and Grasslands for Middle Latitudes, T.N. 197; 1997-\$20

840 The Effect of Temperature on the Citrus Crop, T.N. 198; $1997-\$ 20$

841 Climate Variability, Agriculture and Forestry: An Update T.N. 199; 1997-\$23

\section{WORLD WEATHER WATCH PLANNING REPORTS}

553 Conversion of Grid-Point Data into Meteorological Maps with a Mini-Computer System, WWW 37, 1980-\$20

621 Very Short-range Forecasting Observations, Methods, and Systems, WWW 38, 1983-\$23

\section{WORLD WEATHER WATCH STATUS REPORTS}

714 World Weather Watch-14th Status Report on Implementation, 1989-\$29

753 World Weather Watch-15th Status Report on Implementation, $1992-\$ 33$ 
790 World Weather Watch-16th Status Report on Implementation, 1994-\$39

823 World Weather Watch-17th Status Report on Implementation, 1996-\$37

855 World Weather Watch - 18th Status Report on Implementation, 1997-\$31

894 World Weather Watch - 19th Status Report on Implementation, 1999-\$45

922 World Weather Watch-20th Status Report on Implementation, 2001-\$45

\section{GENERAL REFERENCE PUBLICATIONS}

2 Meteorological Services of the World, '94-\$64

47 International List of Selected, Supplementary and Auxiliary Ships, 1998-\$69

117 Climatological Normals (CLINO) for CLIMAT and CLIMAT SHIP stations for the period 1931-1960, 1971$\$ 45$

259 WMO Sea-Ice Nomenclature, 1970 (Vol. I and III, one cover) $-\$ 39$

Vol. I, Terminology and Codes, 1970

Vol. III, International System of Sea Ice Symbols, 1970

634 Guidelines for Comprehensive Data Processing in Operational Hydrology and Land Water Management, 1985-\$39

847 Climatological Normals (CLINO) for the Period 1961$1990,1996-\$ 129$

\section{PUBLICATIONS OF GENERAL INTEREST}

182 International Meteorological Vocabulary, 1992-\$95

309 Radiation Processes in the Atmosphere, 1972-\$65

385 International Glossary of Hydrology, 1992-\$67

411 Information on Meteorological and Other Environmental Satellites, 1994-\$55

523 The Atmosphere Boundary Layer, 1979—\$29

528 WWW-WMO Tropical Cyclone Project-Sub-Project No. 6: Operational Techniques for Forecasting Tropical Cyclone Intensity and Movement, 1979—\$30

542 Climatic Changes and Their Effects on the Biosphere, $1980-\$ 39$

574 Sea-Ice Information Services in the World, 2000— $\$ 55$

613 Monsoons, 1986-\$48

618 Tropical Cyclone Operational Plan for the Southwest Indian Ocean, 1990 - \$44

624 Meteorology Aids Food Production, 1985-\$20

637 Meteorology and Public Safety, 1984-\$20

652 Proceedings of the Technical Conference on Urban Climatology and Its Applications with Special Regard to Tropical Areas (Mexico D.F., 26-30 November 1984), 1986 - $\$ 58$

653 Climate Variations, Drought, and Desertification, 1985$\$ 20$

661 Report of the International Conference on the Assessment of the Role of Carbon Dioxide and of Other Greenhouse Gases in Climate Variations and Associated Impacts, 1986 - $\$ 20$

688 Meteorology and the Media, 1987-\$20

700 Dispersion Processes in Large Scale Weather Prediction6th IMO Lecture, 1989-\$92

706 Meteorology in the Service of Aviation by J. Kastelein, $1988-\$ 20$
708 The Bulletin Interviews, 1988-\$30

709 World Weather Watch 25th Anniversary Brochure, $1989-\$ 20$

712 Mesoscale Forecasting and Its Applications: Lectures Presented at the 40th Session of EC, 1989— \$27

721 A Historical Review of WMO, 1990-\$95

725 IGOSS Plan and Implementation Report, 1989-\$20 The WMO Achievement: 40 Years in the Service of International Meteorology and Hydrology, 1990—\$20

733 Economic and Social Benefits of Meteorological and Hydrological Services, 1990—\$55

738 Meteorological and Hydrological Risk Assessment and Disaster Reduction: Lectures Presented at the 42nd Session of the Executive Council, 1990-\$20

741 WMO and Global Warming, 1990-\$20

745 The Role of WMO in the International Decade for Natural Disaster Reduction, 1990-\$20

748 Climate Change: World Leaders' Viewpoints, 1991-\$20

750 Guide to Moored Buoys and Other Ocean Data Acquisi tions Systems, 1990— $\$ 20$

760 Protecting the Atmosphere, Oceans, and Water Resources: Sustainable Use of Natural Resources, 1992 (WMO and UNCED) - $\$ 20$

761 The World Weather Watch Programme 1992-2001Third WMO Long-Term Plan, 1992-\$20

762 The World Climate Programme 1992-2001-Third WMO Long-Term Plan, Part II, Volume 2, 1992-\$20

763 The Atmospheric Research and Environment Programme 1992-2001-Third WMO Long-Term Plan, Part II, Volume 3, 1992-\$20

764 The Applications of Meteorology Programme 19922001-Third WMO Long-Term Plan, Part II, Volume 3, 1992-\$20

765 The Hydrology and Water Resources Programme 1992 2001-Third WMO Long-Term Plan, Part II, Volume 5, $1992-\$ 20$

766 The Education and Training Programme 1992-2001Third AMO Long-Term Plan, Part II, Volume 6, 1992-\$20

767 The Technical Co-operation Programme 1992-2001Third WMO Long-Term Plan, Part II, Volume 7, 1992-\$20

768 The WMO Long-Term Plan, Overall Policy and Strategy 1992-2001 - Third WMO Long-Term Plan, Part I, 1992$\$ 25$

769 Meteorology and Hydrology for Sustainable Development, 1992-\$20

Third Long-Term Plan, 1992-2001: Summary of Objec tives, Policies, and Strategy, 1992-\$21

777 The Global Climate Observing System (GCOS): Re sponding to the Need for Climate Observations, 1992-\$20

778 WMO and the Ozone Issue, 1992-\$20

782 Aerodome Reports and Forecasts: A User's Handbook, $2001-\$ 21$

786 Meteorology and the Transfer of Technology, 1993-\$21

796 Observing the World's Environment: Weather, Climate and Water, 1994-\$20

799 A Decade Against Natural Disasters, 1994-\$20

801 Assessing a Precious Resource ... Water, 1994-\$20

809 WMO Statement on the Status of the Global Climate in $1993-\$ 20$

814 WMO and the Protection of Climate, 1994-\$20

816 On the Front Line: Public Weather Services, 1994-\$20

817 Beyond the Earth Summit-WMO and the Follow-up to UNCED, 1995-\$20 
819 The Global Climate System Review (1991-1993), 1995$\$ 20$

821 A Response to the Weather and Climate Challenge: The WWW, 1995-\$20

826 WMO Statement on the Status of the Global Climate in 1994 (1995) - \$20

828 The Changing Ozone Layer, 1995-\$20

830 The WMO Long-Term Plan: Overall Policy and Strategy 1996-2005-Fourth WMO Long-Term Plan, Part I, $1996-\$ 25$

831 Fourth WMO Long-Term Plan 1996-2005: Summary of Objectives, Policies, and Strategy, 1996-\$20

832 Climate Information and Prediction Services, 1995-\$20

835 Weather and Sports, 1996-\$20

837 Exchanging Meteorological Data. Guidelines on Relation ships in Commercial Meteorological Activities-WMO Policy and Practice, 1996-\$21

838 1995, 1996-\$20

843 Climate and Human Health, 1996-\$20

844 Climate and Urban Development, 1996-\$20

848 WMO and Climate Change, 1996-\$20

849 Food Security: The Climate Factor, 1996-\$20

853 Weather and Water in Cities, 1997-\$20

856

857

858

The Global Climate System Review (1994-1996) — \$30

The World's Water: Is There Enough?, 1997—\$20

WMO Statement on the Status of the Global Climate in $1996-\$ 20$

861

Weather \& the Media: A Press Relations Guide, 1997_$\$ 20$

862 GHOST - Global Hierarchical Observing Strategy, 1997$\$ 20$

863 Mobilizing Resources for Technical Cooperation, 1997$\$ 20$

864 Stepping Forward-Implementation of the WMO CLIPS Project, 1997-\$20

865

869

871

872

The Bulletin Interviews-1989-1997-\$95

Climate, Drought and Desertification, 1997—\$20

Weather, Oceans and Human Activity, 1997-\$20

The Global Observing System of the World Weather Watch, 1997-\$20

Integrated Programme on Hydrometeorology and Monitoring of Environment in CASPAS, 1997-\$20

WHYCOS: World Hydrological Cycle Observing System, $1998-\$ 20$

WMO Statement on the Status of the Global Climate in 1997, 1998-\$20

WMO and the World's Water, 1998-\$20

WMO and the Further Implementation of AGENDA 21$\$ 20$

Weather, Climate and Health $-\$ 20$

WMO Statement on the Status of the Global Climate in $1998-\$ 20$

WMO Support for Small Island Developing States- $\$ 20$

Building for the 21 st Century- $\$ 20$

The 1997-1998 El Niño Event: A Scientific and Technical Retrospective, 1999-\$43

Early Warning Systems for Drought and Desertification: Role of National Meteorological and Hydrological Services, 1999-\$20

Fifth WMO Long-term Plan (2000-2009), 2000-\$65

Fifth WMO Long-term Plan (2000-2009): Summary for

Decision Makers, 2000—\$20

912 WMO - 50 Years of Service, 2000-\$20

913 WMO Statement on the Status of the Global Climate in 1999, 2000-\$20

914 Proceedings of the WMO/UNESCO Sub-Forum on Science and Technology in Support of Natural Disaster Reduction, 1999-\$75

916 Forecasting in the 20th Century, 2000-\$25

917 Operational provision for the hydrometeorological safety of the Transport Corridor Europe-Caucasus-Asia (TRACECA), 2000-\$20

919 Volunteers for weather, climate and water, 2001 - \$20

920 WMO statement on the status of the global climate in 2000, 2001-\$20

925 Exchanging hydrological data and information-WMO policy and practice, 2001-\$20

933 Weather, Climate and Food Security, 2001 - \$20

936 Reducing vulnerability to weather and climate extremes, $2002-\$ 20$

\section{COMMISSION, CONGRESS, EXECUTIVE, AND ANNUAL REPORTS}

508 Resolutions of Congress and Exec. Committee, 1985-\$50

614 Scientific Lectures Presented at the 9th World Meteoro logical Congress, Geneva 1983; 1985-\$25

649 Scientific Lectures Presented at the 36th Session of the WMO Executive Committee, 1984-\$20

682 WMO Executive Council 39th Session-Abridged Final Report, (1987); 1988-\$28

689 Annual Report of the World Meteorological Organization, (1987); 1988-\$48

698 Tenth World Meteorological Congress (1987)_Proceedings, 1988-\$29

699 Commission for Basic Systems-Abridged Final Report of the Ninth Session (1988), 1988-\$58

723 Forty-First Session of the Executive Council (1989): Abridged Report with Resolutions-\$32

734 Annual Report of WMO (1989) 1990—\$26

743 Commission for Atmospheric Sciences-Abridged Final Report of the Tenth Session (1990), 1991-\$26

746 Annual Report of WMO (1990), 1991-\$27

751 Commission for Basic Systems-Abridged Final Report of the Extraordinary Session (1990), 1991 - \$48

756 Eleventh World Meteorological Congress (1991)Abridged Report with Resolutions, 1991 — \$31

757 Eleventh World Congress (1991) - Proceedings, 1991$\$ 35$

758 Forty-Third Session of the Executive Council (1991)Abridged Report with Resolutions, 1991 - \$25

771 Special Topics on Climate-Lectures Presented at the $42 \mathrm{nd}$ Session of the WMO Executive Council (1990), 1993-\$20

774 Annual Report of WMO (1991), 1992 - \$33

775 Commission for Agricultural Meteorology-Abridged Final Report of the Tenth Session (1991), 1992-\$25

780 Forty-fourth Session of the Executive Council (1992)$\$ 29$

783 Regional Association II (Asia)_-Abridged Final Report of the Tenth Session (1992), 1993-\$37

784 Commission for Basic Systems-Abridged Final Report of the Tenth Session (1992), 1993-\$45

785 Proceedings of the Technical Conference on Tropical Aeronautical Meteorology (TECTAM-92), 1993-\$73

787 Annual Report of the WMO, 1992 - \$33 
789 Commission for Hydrology - Abridged Final Report of the Ninth Session (1993), 1993-\$31

791 Commission for Climatology - Abridged Final Report of the Eleventh Session, 1993-\$25

792 Commission for Marine Meteorology-Abridged Final Report of the Eleventh Session, 1993-\$39

793 Regional Association IV (North and Central America) Abridged Final Report of the Eleventh Session, 1993-\$25

794 Forty-Fifth Session of the Executive Council-Abridged Report with Resolutions, 1993-\$33

795 Scientific lectures at CG-11, 1993-\$21

798 Climate Change Issues-Lectures Presented at the 44th Session of the WMO Executive Council (1992), 1994-\$20

800 Annual Report of the World Meteorological Organization, $1993-\$ 31$

805 Lectures Presented at the Forty-Fifth Session of the WMO Executive Council (1993), 1994-\$21

807 Commission for Instruments and Methods of Observa tion-Abridged Final Report of the 11th Session, 1994-\$27

808 Commission for Atmospheric Sciences-Abridged Final Report of the 11th Session, 1994-\$23

815 Commission for Basic Systems-Abridged Final Report of the Extraordinary Session, 1994-\$37

818 Commission for Aeronautical Meteorology-Abridged Final Report of the 10th Session, 1994-\$25

822 Lectures Presented at the Forty-Sixth Session of the WMO Executive Council (1994), 1995-\$20

824 Annual Report of the World Meteorological Organization, $1994-\$ 27$

825 Commission for Agricultural Meteorology-Abridged Final Report of the 11th Session, 1995-\$27

827 Twelfth World Meteorological Congress (1995) Abridged Final Report with Resolutions-\$37

829 Forty-seventh Session of the Executive Council (1995)Abridged Final Report with Resolutions- $\$ 20$

836 Annual Report of the World Meteorological Organization, $1996-\$ 27$

845 Scientific Lectures Presented at the 12th World Meteorological Congress - 1995; 1996-\$43

846 Forty-Eighth Session of the Executive Council (1996) Abridged Final Report with Resolutions, 1996-\$39

852 Commission for Hydrology - Abridged Final Report of the 10th Session, 1997-\$23

854 Commission for Basic Systems-Abridged Final Report of the 11th Session, 1997-\$33

859 Annual Report of the World Meteorological Organization, $1996-\$ 27$

860 Commission for Marine Meteorology - Abridged Final Report of the 12th Session, 1997-\$43

866 Scientific Lectures Presented at EC XLVIII (1996), 1997$\$ 35$

867 Forty-Ninth Session of the Executive Council (1997) Abridged Final Report with Resolutions, 1997-\$41

870 Commission for Climatology-Abridged Final Report of the 12th Session (1997), 1997-\$29

875 Annual Report of the World Meteorological Organization (1997), 1998-\$27

879 Commission for Atmospheric Sciences-Abridged Final Report of the 12th Session (1998), 1998-\$23

881 Commission for Instruments \& Methods of ObservationAbridged Final Report of the 12th Session, 1997-\$33

883 Fiftieth Session of the Executive Council, 1998-Abridged Final Report with Resolutions, 1998-\$53
893 Commission for Basic Systems-Abridged Final Report of the Extraordinary Session, 1998-\$71

895 Annual Report of the WMO, 1998-\$27

899 Commission for Aeronautical Meteorology-Abridged Final Report of the 11th Session, 1999-\$35

900 Commission for Agricultural Meteorology-Abridged Final Report of the Twelfth Session (1999), 1999—\$45

902 13th World Meteorological Congress-Abridged Final Report with Resolutions- $\$ 61$

903 51st Session of the Executive Council-Abridged Final Report with Resolutions-\$27

907 Annual Report of the World Meteorological Organization 1999, 2000-\$27

910 Lectures Presented at the Forty-Ninth Session of the WMO Executive Council, 2000-\$21

911 Lectures Presented at the Fiftieth Session of the WMO Executive Council, 2000-\$21

915 Executive Council, fifty-second session (2000) - Abridged final report with resolutions, 2000-\$39

918 Annual Report of the World Meteorological Organization, 2000, 2001-\$31

921 Commission for Hydrology, eleventh session (2000)-Abridged final report with resolutions and recommendations, $2001-\$ 25$

923 Commission for Basic Systems, twelfth session (2000)-Abridged final report with resolutions and recommendations, $2001-\$ 75$

929 Executive Council, fifty-third session (2001) - Abridged final report with resolutions, 2001 $-\$ 51$

931 Joint WMO/IOC Technical Commission for Oceanogra phy and Marine Meteorology, first session-Abridged final report with resolutions and recommendations, 2001 $-\$ 81$

932 Thirteenth World Meteorological Congress (1999) Proceedings, 2001- $\$ 43$

935 Annual Report of the World Meteorological Organization, 2001, 2002-\$29

\section{REPORTS OF SESSIONS OF REGIONAL ASSOCIATIONS}

678 Regional Association I (Africa) - Abridged Final Report of the Ninth Session (1986), 1987-\$37

711 Regional Association II (Asia) 9th Session-Abridged Final Report, 1989-\$38

719 Regional Association IV (North and Central America) Abridged Final Report of the Tenth Session-\$31

730 Regional Association V (Southwest Pacific) - Abridged Final Report of the Tenth Session-\$26

736 Regional Association VI (Europe) - Abridged Final Report of the Tenth Session, 1990 - \$20

755 Regional Association I (Africa) - Abridged Final Report of the Tenth Session (1990), 1991— $\$ 38$

783 Regional Association II (Asia) - Abridged Final Report of the Tenth Session, 1992-\$37

793 Regional Association IV (North and Central America) Abridged Final Report of the 11th Session, 1993-\$25

797 Regional Association III (South America) - Abridged Final Report of the 11th Session (1993), 1994-\$23

811 Regional Association V (South-West Pacific) - Abridged Final Report of the 11th Session, 1994-\$25

812 Regional Association VI (Europe) - Abridged Final Report of the 11th Session (1994) - \$31 
820 Regional Association I (Africa)-Abridged Final Report of the 11th Session, 1994-\$29

851 Regional Association II (Asia) -Abridged Final Report of the 11th Session, 1996-\$35

868 Regional Association IV (North and Central America) Abridged Final Report of the 12th Session, 1997-\$25

874 Regional Association III (South America)-Abridged Final Report of the 12th Session, 1997-\$21

882 Regional Association VI (Europe)-Abridged Final Report with Resolutions, 1998-\$20

888 Regional Association V (South-West Pacific), 1998-\$20

890 Regional Association V (South-West Pacific)-Abridged Final Report with Resolutions, 1998-\$39

891 Regional Association I (Africa) -Abridged Final Report with Resolutions, 1998-\$55

924 Regional Association II (Asia), twelfth session (2000)-Abridged final report with resolutions, 2001 - \$55

927 Regional Association IV (North and Central America), thirteenth session (2001) - Abridged final report with resolutions, $2001-\$ 33$

\section{WMO CLOUD SHEET, 1986}

The dimensions of the WMO Cloud Sheet are $39 \times 83 \mathrm{~cm}$. This popular sheet is printed on glossy paper and can be mounted on a hard backing. Thirty eight color photographs were selected to assist not only the marine observer, but also as a general reference for all professional or amateur meteorological observers.

QUANTITY PRICE PER CLOUD SHEET

(Prices do not include shipping and handling)

\begin{tabular}{rr}
\hline $1-10$ & $\$ 5.00$ \\
$11-30$ & $\$ 4.00$ \\
$31-50$ & $\$ 3.00$ \\
$51-100$ & $\$ 2.75$ \\
$101-500$ & $\$ 2.50$ \\
$501-1000$ & $\$ 2.25$ \\
$1000+$ & $\$ 2.00$
\end{tabular}

Shipping and handling charges: $1-10-\$ 5 /$ sheet; $11-100-\$ 10 / 10$ sheets. Contact AMS for shipping and handling costs for orders over 100 sheets.

Questions concerning WMO publications should be addressed to: Beth Farley, AMS, 45 Beacon Street, Boston, MA 02108-3693; (617) 227-2426, x214. All orders for WMO Publications are for United States and Canada only.

\section{Call for Weather-Related Art and Photos}

The Bulletin of the American Meteorological Society invites submission of original, weather-related art and photos for potential publication in future issues of the magazine. The Bulletin staff is especially interested in work that is artistic and creative, featuring a unique, interesting perspective; chosen works will be used to help add more graphic appeal to the Bulletin. Specific use of the images will be determined by the production staff. Please be aware that your submission will not be peer reviewed-we will be looking at submissions more from an aesthetic viewpoint than a scientific one. (Photos intended for scientific publication should be submitted following normal Bulletin guidelines for peer-reviewed submissions.) Nonetheless, all submissions will be given equal consideration.

We hope that you will take this ongoing opportunity to inspire your colleagues and shape the look of your Society's publication. Ownership of the works will be retained by the artist/photographer; we do not offer payment for published submissions.

Submission requirements: For artwork, please do not submit the original work of art-send only a high-quality color photo of the piece. For art and all other photographs submitted for consideration, send only first-quality, camera-ready prints or slides (no photocopies, please). Submissions will not be returned unless accompanied by a self-addressed envelope with correct postage.

Please include with the submission your name, the title of the work (if applicable), and any other relevant information. If a description of the submission would be helpful, please include a succinct caption.

Please submit your work to: David Gershman, Manager of Art and Design, AMS, 45 Beacon St., Boston, MA 02108-3693. 